\title{
Chronology of early Cambrian biomineralization
}

\author{
ARTEM KOUCHINSKY*†, STEFAN BENGTSON*, BRUCE RUNNEGAR \\ CHRISTIAN SKOVSTED*, MICHAEL STEINER \& \& MICHAEL VENDRASCO \\ *Department of Palaeozoology, Swedish Museum of Natural History, Box 50007, SE-104 05 Stockholm, Sweden \\ $\ddagger$ Department of Earth and Space Sciences, University of California Los Angeles, CA 90095-1567, USA

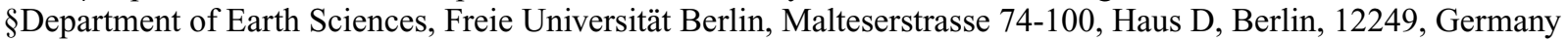 \\ ๆDepartment of Biological Science (MH-282), California State University, Fullerton, P.O. Box 6850 Fullerton, \\ CA $92834-6850$
}

(Received 16 September 2010; accepted 5 February 2011; first published online 26 August 2011)

\begin{abstract}
Data on the first appearances of major animal groups with mineralized skeletons on the Siberian Platform and worldwide are revised and summarized herein with references to an improved carbon isotope stratigraphy and radiometric dating in order to reconstruct the Cambrian radiation (popularly known as the 'Cambrian explosion') with a higher precision and provide a basis for the definition of Cambrian Stages 2 to 4. The Lophotrochozoa and, probably, Chaetognatha were first among protostomians to achieve biomineralization during the Terreneuvian Epoch, mainly the Fortunian Age. Fast evolutionary radiation within the Lophotrochozoa was followed by radiation of the sclerotized and biomineralized Ecdysozoa during Stage 3. The first mineralized skeletons of the Deuterostomia, represented by echinoderms, appeared in the middle of Cambrian Stage 3. The fossil record of sponges and cnidarians suggests that they acquired biomineralized skeletons in the late Neoproterozoic, but diversification of both definite sponges and cnidarians was in parallel to that of bilaterians. The distribution of calcium carbonate skeletal mineralogies from the upper Ediacaran to lower Cambrian reflects fluctuations in the global ocean chemistry and shows that the Cambrian radiation occurred mainly during a time of aragonite and high-magnesium calcite seas.
\end{abstract}

Keywords: Cambrian, radiation, biomineralization, evolution, stratigraphy.

\section{Introduction}

The term 'Cambrian radiation' (popularly known as the 'Cambrian explosion') is embedded in modern scientific literature and was coined for the early Cambrian geologically rapid diversification of metazoans. Most of these early Cambrian metazoans appear to represent members of the stem lineage of extant clades. The first appearances of these groups are clustered geochronologically by higher-rank phylogeny (Budd, 2003; Landing \& Westrop, 2004; Li et al. 2007). Budd (2003) and Budd \& Jensen (2000, 2003) argued that this clustering reflects the true sequence of divergence of these high-ranking groups and implies rather late origins, probably near the Precambrian-Cambrian boundary, followed by their rapid evolutionary radiation in the early Cambrian. This event is marked in the fossil record by the first appearances and increase in diversity and abundance of many groups of animals, accompanied by the independent acquisition of mineralized skeletons in many lineages.

Skeletal biomineralization was likely an epiphenomenon of the general radiation of body plans and tissues (Bengtson, 2004). Skeletal elements are considered principal aspects of many body plans, and their origin and diversification are thought to have helped spur evolutionary radiation in the Cambrian. Skeletons

†Author for correspondence: artem.kouchinsky@nrm.se certainly diversified along with the taxa that obtained them, with $80 \%$ of modern skeletal morphotypes present by the middle Cambrian (Thomas, Sherman $\&$ Stewart, 2000). The diversity of minerals employed in early skeletalized animals suggests a limit to the role of ocean geochemistry in the emergence of skeletons, although the primary acquisition of particular skeletal carbonate mineralogies was likely driven by the ocean geochemistry (Zhuravlev, 1993; Bengtson, 1994, 2004; Ushatinskaya \& Zhuravlev, 1994; Hardie \& Stanley, 1997; Stanley \& Hardie, 1998; Porter, 2007; Zhuravlev \& Wood, 2008; Kiessling, Aberhan \& Villier, 2008). Mineralized skeletal parts are only one of many strategies to escape predation, since skeletonized species constitute a minority in modern and ancient marine ecosystems (e.g. Conway Morris, 1986). However, it was probably the antipredatory selective advantage of mineral skeletons that drove early evolution in many clades (Bengtson, 1994, 2004). Further diversification of predators and their increased pressure on epibenthos in the Cambrian may well have triggered the early Cambrian rapid evolutionary radiation in different clades (Bengtson, 1994, 2004).

In order to understand in detail the fossil record of early Cambrian skeletal biomineralization and structure of the Cambrian radiation, a betterresolved sequence of first appearances of mineralized skeletons in the early Cambrian class-to-phylumlevel animal groups is presented herein. Our study 


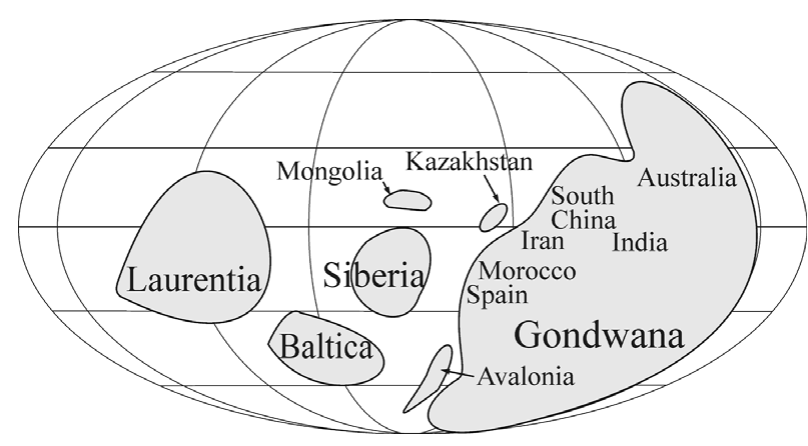

Figure 1. Schematic palaeogeographic map for the early Cambrian with crustal units discussed in this paper (adapted from Fatka, Kraft \& Szabad, 2011 and Álvaro et al. in press).

incorporates a new carbon isotope chemostratigraphy of the northern Siberian Platform, where a continuous isotopic and fossil record is known from mainly carbonate sections of the Cambrian System (online Fig. S1 at http://journals.cambridge.org/geo). The Siberian data are stratigraphically correlated with those from other well-known units of the Cambrian world, such as Western Mongolia, Kazakhstan,
South China, Iran and India, Australia, Avalonia, the Mediterranean region of West Gondwana, Laurentia and Baltica (Fig. 1; online Appendices $1 \& 2$ at http://journals.cambridge.org/geo). This record, supported by available chemostratigraphy and radiometric dating, allows us to constrain the timing of the first appearances of skeletonization in various animal groups (Fig. 2).

\section{Stratigraphical setting}

The traditional three-fold subdivision of the Cambrian System into Lower, Middle and Upper Cambrian series has been abandoned recently in favour of a subdivision into four series of ten stages (Babcock et al. 2005; Babcock \& Peng, 2007). The uppermost two series of the revised Cambrian timescale more or less correspond to the traditional Middle and Upper Cambrian series, while the former Lower Cambrian is subdivided into two series. The new Cambrian timescale begins with the Fortunian Stage of the Terreneuvian Series, the base of which is defined as the first occurrence of the trace fossil Treptichnus pedum

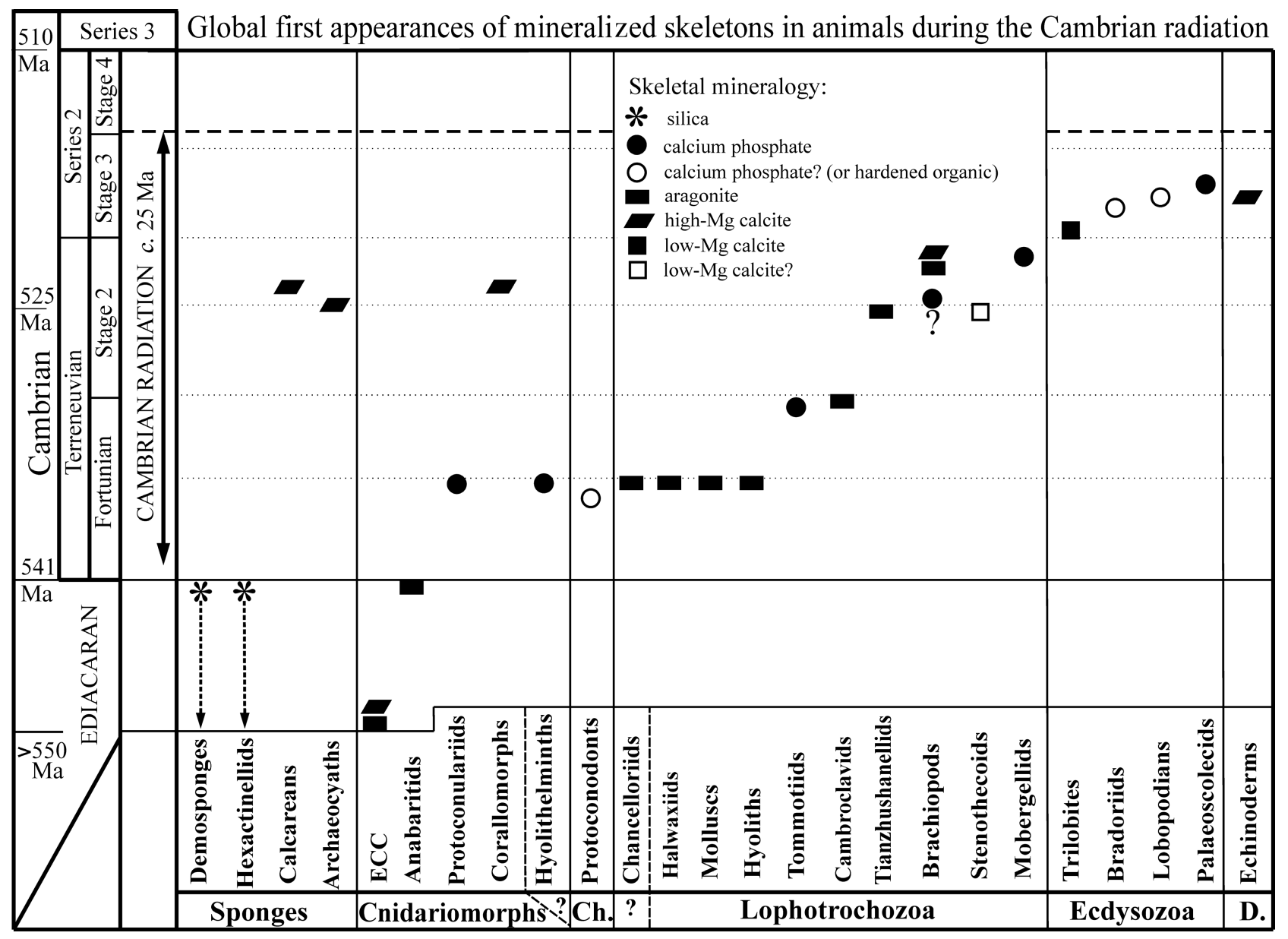

Figure 2. Global first appearances of mineralized skeletons in animals during the Cambrian radiation. Question marks indicate uncertainty in first appearance or place within higher-ranked group; affinities of chancelloriids to the Lophotrochozoa and hyolithelminths to the Cnidaria are uncertain (see main text and online Appendix 1 at http://journals.cambridge.org/geo). Cambroclavids (with paracarinachitids included) are tentatively attributed to the Lophotrochozoa. Vertical dashed lines for sponges reflect sporadic occurrence of their presumably biomineralized spicules in the Precambrian (see main text and online Appendix 1 at http://journals.cambridge.org/geo). ECC - Ediacaran calcified cnidariomorphs; Ch - Chaetognatha; D - Deuterostomia. 


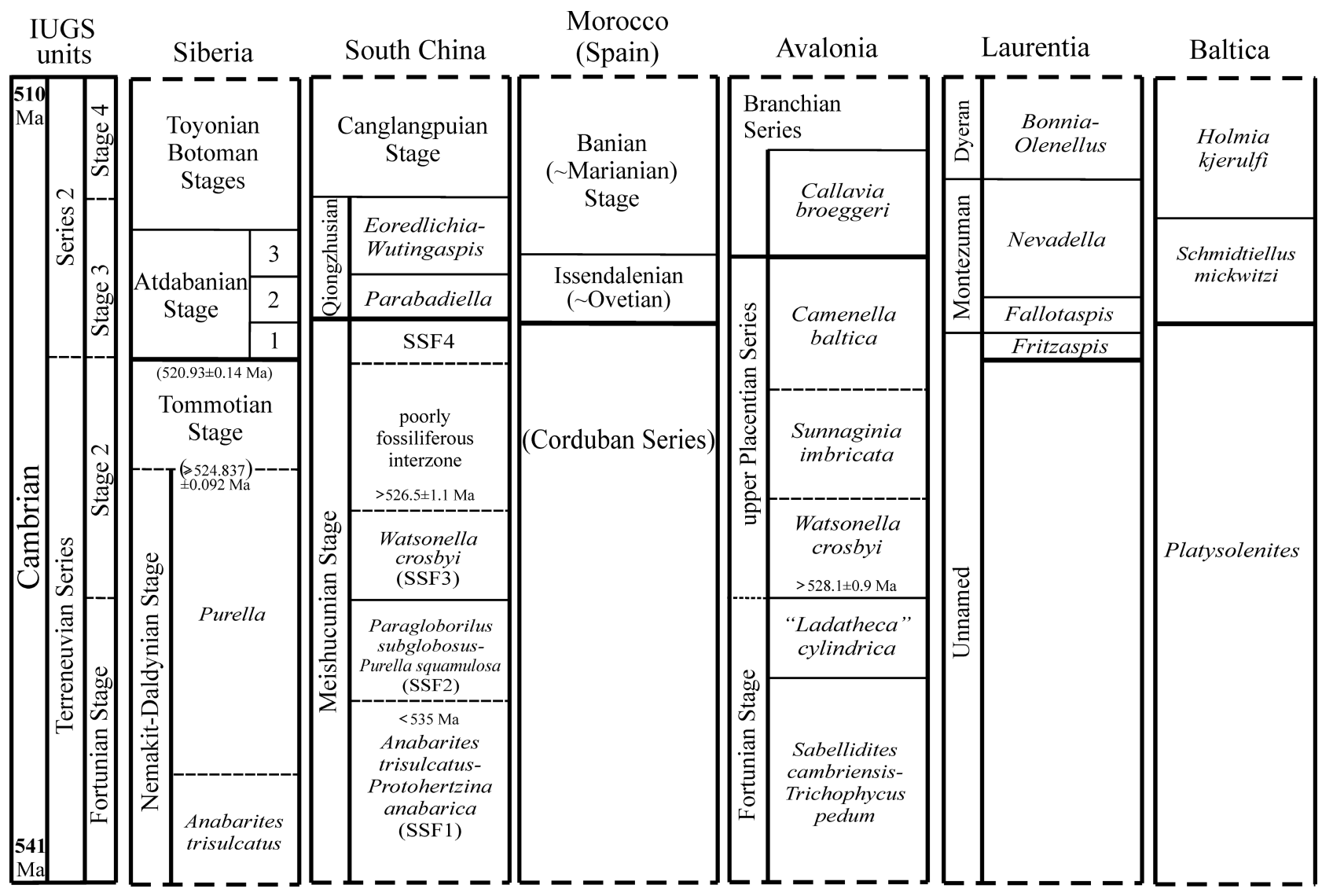

Figure 3. Correlation chart of the major crustal units discussed in this paper. It is formally accepted that the Purella Zone corresponds to the entire upper part of the Nemakit-Daldynian Stage (e.g. Rozanov et al. 2008). According to the chemostratigraphic record (e.g. Kaufman et al. 1996; see also Fig. 4 herein), a hiatus of disputed duration exists, however, at the base of the Tommotian Stage in its stratotype in the southeastern Siberian Platform. The Purella Zone is shown herein to cover its duration, since the missing record exists in the northern part of the Platform. The first occurrences of trilobites are highlighted by thick horizontal lines within the Stage 3 interval. The Atdabanian Stage is subdivided into three parts (lower, middle and upper): 1 - Profallotaspis jakutensis and Repinaella zones; 2 - Delgadella anabara Zone; 3 - Judomia Zone. SSF4 = Sinosachites flabelliformis-Tannuolina zhangwentangi Assemblage Zone. Absolute ages for the Precambrian-Cambrian boundary after Bowring et al. 2007; Cambrian Series 2-Series 3 boundary after Ogg, Ogg \& Gradstein, 2008. Absolute ages of the lower and upper boundaries of the Tommotian Stage are based on data from Morocco (see main text and Maloof et al. 2005, 2010a,b). The fossiliferous Watsonella crosbyi Zone in China is older than $526.5 \pm$ 1.1 Ma (after Compston et al. 2008) and its lower boundary in Avalonia is shown to be older than $530.7 \pm 0.9 \mathrm{Ma}$ (Isachsen et al. 1994 ) or $528.1 \pm 0.9 \mathrm{Ma}$ (Compston et al. 2008). That boundary is, however, younger than $535.2 \pm 1.7 \mathrm{Ma}$, a combined depositional age for Bed 5 (shown as < $535 \mathrm{Ma}$ in figure) from the upper Anabarites trisulcatus-Protohertzina anabarica Zone (Zhu et al. 2009; see main text for discussion).

at Fortune Head in Newfoundland (Landing et al. 2007). It is anticipated that the base of Cambrian Series 2 and Stage 3 will coincide with the first appearance of trilobites (Babcock \& Peng, 2007), here interpreted to correlate with the base of the Atdabanian Stage in Siberia (Fig. 3). The remaining boundaries within Series 1-2 are less certain. In the present work, we will provisionally correlate the base of Cambrian Stage 2 of the Terreneuvian Series with the base of the Watsonella crosbyi Zone of Avalonia and South China (see Landing et al. 2007; Li et al. 2007) and the base of Cambrian Stage 4 with the lower Botoman Stage in Siberia (Fig. 3). The base of Cambrian Series 3, Stage 5 is presently highly debated, but is here correlated with the first occurrence of the trilobite Oryctocephalus indicus, which more or less coincides with the traditional Lower-Middle Cambrian boundary in many areas. The further development of the chronostratigraphy of Cambrian Series 1 and
2 is directly related to our precision in dating and correlation of the first appearances of diverse skeletal fossils in principal Cambrian sequences.

The age of the Precambrian-Cambrian boundary, marked worldwide by a negative carbon isotope anomaly, is dated in the well-constrained section in Oman to $542 \pm 0.3 \mathrm{Ma}$ (Amthor et al. 2003), later revised to $541 \pm 0.13 \mathrm{Ma}$ (Bowring et al. 2007). An associated biotic crisis is inferred from the disappearance of the Ediacaran biota (e.g. Kimura \& Watanabe, 2001; Narbonne, 2005). As recognized herein, the Cambrian radiation event ('Cambrian explosion') occurred within a period of c. $25 \mathrm{Ma}$. The Cambrian radiation began with the diversification of skeletonized bilaterians following this negative anomaly and concluded with the Botoman-Toyonian biotic crisis (Zhuravlev \& Wood, 1996; Zhuravlev, 2001; Li et al. 2007), which was the first mass extinction episode in the Phanerozoic (Signor, 1992). The onset of the crisis on the Siberian 


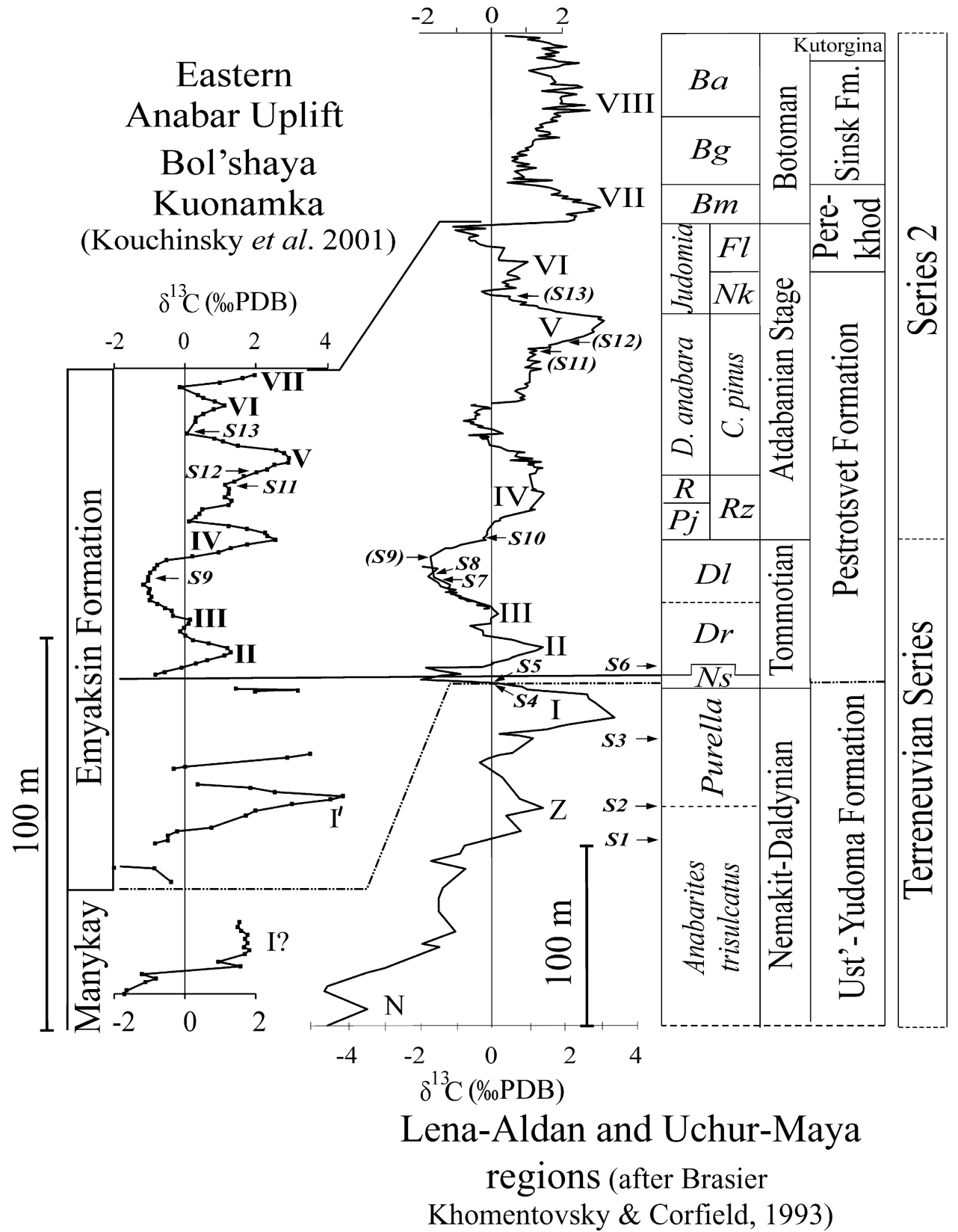

Figure 4. First appearances of skeletal fossil groups on the Siberian Platform (S1-S13, see Appendix 1 for details) in the key sections correlated with the $\delta^{13} \mathrm{C}$ chemostratigraphy (after Brasier, Khomentovsky \& Corfield, 1993; Brasier et al. 1994b; Kouchinsky et al. 2001). Zones: Ns - Nochoroicyathus sunnaginicus; Dr-Dokidocyathus regularis; Dl-Dokidocyathus lenaicus-Tumuliolynthus primigenius; $R z$ - Retecoscinus zegebarti; C. pinus - Carinacyathus pinus; Nk - Nochoroicyathus kokoulini; Fl - Fansycyathus lermontovae; $P j$-Profallotaspis jakutensis; $R$-Repinaella; D. anabara-Delgadella anabara; Bm-Bergeroniellus micmacciformis; $B g-$ Bergeroniellus gurarii; $B a-$ Bergeroniellus asiaticus. Numbers in brackets are projections of the corresponding first appearances in the Atdabanian Stage of the Anabar Uplift onto the Lena-Aldan reference scale.

Platform (Sinsk event), is marked by decreasing $\delta^{13} \mathrm{C}$ values above peak VII of the Siberian reference scale (Brasier et al. 1994a,b; Zhuravlev \& Wood, 1996; Li et al. 2007; Fig. 4).

The Cambrian radiation interval shows prominent and frequent oscillations of the carbon isotope ratio (e.g. Brasier et al. 1994a,b; Brasier \& Sukhov, 1998; Figs 4, 5). An overall rising trend in $\delta^{13} \mathrm{C}$ values characterizes the sedimentary sequence of the Fortunian Stage in Siberia, Mongolia, China and Western Gondwana. SHRIMP U-Pb zircon analyses from the lower part of this trend in South China provide a revised age of $539.4 \pm 2.9 \mathrm{Ma}$ (Compston et al. 2008), whereas secondary ion mass spectrometry (SIMS) of the same tuffite (Bed 5 of the Meishucun section) resulted in a c. 533 Ma estimate (Brooks et al. 2006). Nano-SIMS measurements by Sawaki et al. (2008) provided an age estimate of $536.5 \pm 2.5 \mathrm{Ma}$ for Bed 5, whereas SIMS analyses by Zhu et al. (2009) yielded an age of 536.7 \pm 3.9 Ma. A combined depositional age for Bed 5 was calculated as $535.2 \pm 1.7$ Ma by Zhu et al. (2009). The fauna known from below Bed 5 is considered herein to be older than $535 \mathrm{Ma}$ (Figs 2, 3). The dated bed is situated in the upper part of the Anabarites trisulcatusProtohertzina anabarica (SSF1) Assemblage Zone of the lower Meishucunian Stage. 


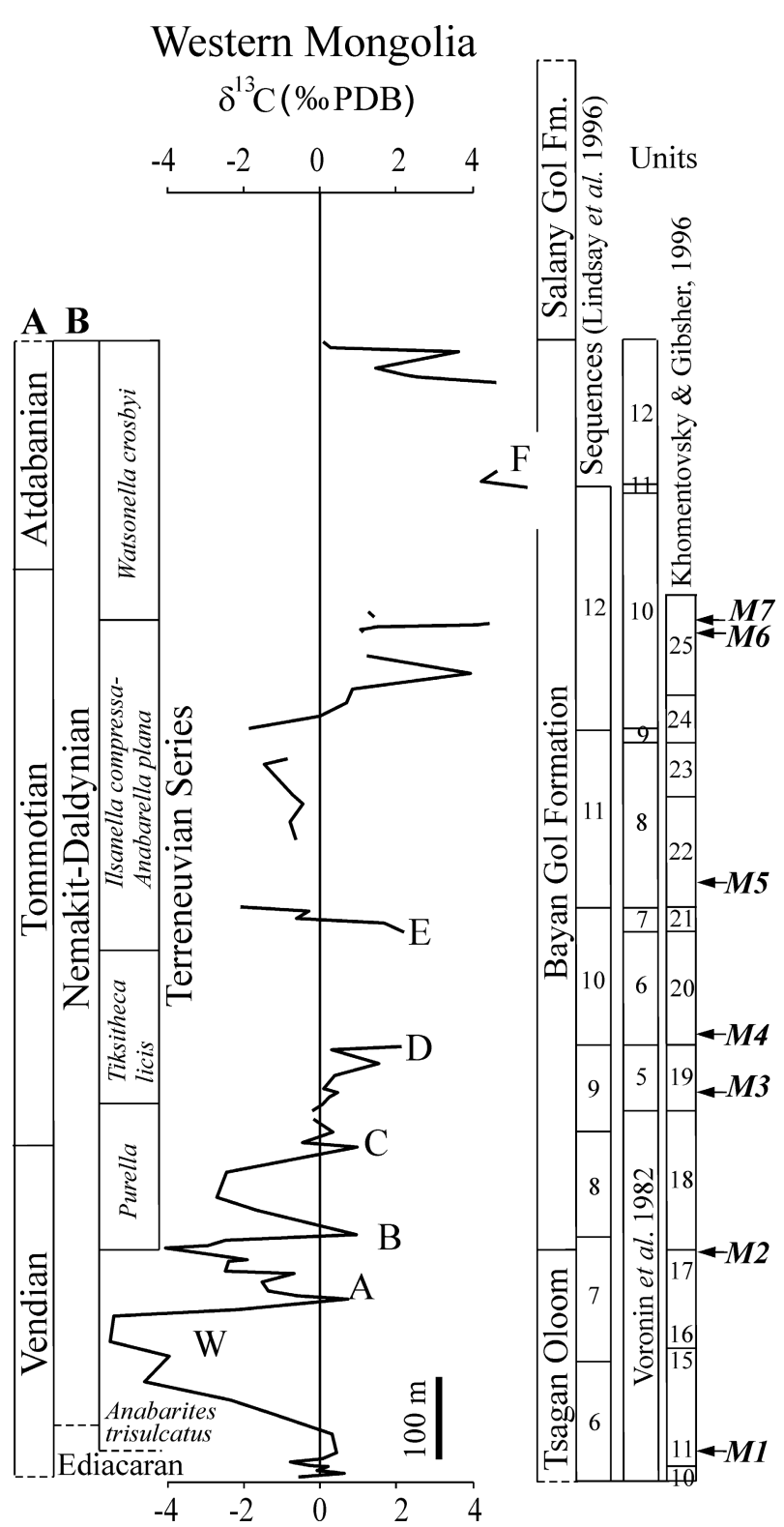

Figure 5. First appearances of skeletal fossil groups in the Tsagan Oloom and Bayan Gol formations of Western Mongolia (M1-M7, see Appendix 2 for details) (after Brasier et al. 1996, fig. 6), in the Tsagan Gol, Bayan Gol and Salany Gol sections composite. Features of the $\delta^{13} \mathrm{C}$ curve, from $\mathrm{W}$ to $\mathrm{C}$ after Brasier et al. (1996, fig. 5) and from D to F after fig. 7 therein; adapted for unit thickness of the Bayan Gol Formation in Brasier et al. 1996, fig. 6a. Zones after Brasier et al. (1996). A - correlation with Siberia, after Voronin et al. (1982), Astashkin et al. (1995), Khomentovsky \& Gibsher (1996) and Esakova \& Zhegallo (1996); B - chemostratigraphic correlation, after Brasier et al. (1996).

The rising trend of $\delta^{13} \mathrm{C}$ values continues into the Cambrian Stage 2, where several highly positive peaks preceding the Tommotian Stage in Siberia top it (Fig. 4). A single preserved prominent positive peak from the same rising trend is present in the Watsonella crosbyi (SSF3) Assemblage Zone of the Middle Meishucunian Stage in South China and is older than $526.5 \pm 1.1 \mathrm{Ma}$ (after Compston et al. 2008). The lower boundary of the Cambrian Stage 2 and Watsonella crosbyi Zone has been preliminarily estimated to be close to $530 \mathrm{Ma}$ (Landing et al. 2007). The estimate is based on the absolute age of $530.7 \pm 0.9$ Ma obtained from the Watsonella crosbyi Zone in Avalonia (Isachsen et al. 1994), but the date was revised to $528.1 \pm 0.9 \mathrm{Ma}$ by Compston et al. (2008, p. 417). The uppermost peak in the rising trend of $\delta^{13} \mathrm{C}$ values within Stage 2 is dated in Morocco to $525.4 \pm 0.5 \mathrm{Ma}$ (Maloof et al. 2005), later revised to $525.343 \pm 0.088 \mathrm{Ma}$ (Maloof et al. 2010a,b). The high-resolution successions of $\delta^{13} \mathrm{C}$ peaks in Morocco and Siberia (Brasier et al. 1994b; Kouchinsky et al. 2007) proved to be very similar, and their correlation resulted in a $c$. 525 Ma estimate of the age of the Nemakit-DaldynianTommotian boundary dated in Morocco to $524.837 \pm$ $0.092 \mathrm{Ma}$ (Maloof et al. 2010a,b). Chemostratigraphic $\delta^{13} \mathrm{C}$ correlation with radiometrically dated sections of Morocco allows dating of the lower boundary of the Atdabanian Stage in Siberia to a maximum age of $520.93 \pm 0.14 \mathrm{Ma}$ (Maloof et al. 2010a,b), thereby providing an estimate of $c$. $521 \mathrm{Ma}$ for the upper boundary of Stage 2 and the Terreneuvian Series.

A recalculated age of $515.56 \pm 1.16 \mathrm{Ma}$ attributed to the upper Antatlasia gutta-pluviae Zone of the Moroccan Banian Stage (originally $517.0 \pm 1.5 \mathrm{Ma}$ by Landing et al. 1998) can be correlated with the Botoman Stage (probably, the Bergenellious asiaticus Zone) of Siberia and the Bonnia-Olenellus Zone of Laurentia (Zhuravlev, 1995; Landing et al. 1998; Maloof et al. 2010a). The conclusion of the Cambrian radiation and the onset of the Botoman-Toyonian biotic crisis are, therefore, dated herein to be c. $515 \mathrm{Ma}$ (Figs 2, 3). The upper boundary of the Cambrian Series 2 is estimated to be c. $510 \mathrm{Ma}$ (Ogg, Ogg \& Gradstein, 2008), because it is somewhat younger than the estimated age of $511 \pm 1 \mathrm{Ma}$ for the upper Branchian Series of Avalonia (Landing et al. 1998).

\section{2.a. Siberia}

The former Lower Cambrian includes on the Siberian Platform and in the Altai-Sayan Folded Area the Tommotian, Atdabanian, Botoman and Toyonian stages, in ascending order (Rozanov \& Sokolov, 1984; Rozanov et al. 2008; Varlamov et al. 2008). The lowermost Cambrian strata (approximately, Fortunian Stage equivalent) were recognized on the Platform as the Nemakit-Daldynian (or Manykayan Stage by some authors, e.g. Missarzhevsky, 1982, 1989; Val'kov, 1982, 1987; see discussion in Khomentovsky \& Karlova, 2002, 2005). The Nemakit-Daldynian Stage is now subdivided into the Anabarites trisulcatus and Purella antiqua zones, in ascending order (Khomentovsky \& Karlova, 1993, 2002). In the Lena-Aldan and UchurMaya regions of the southeastern Siberian Platform, the first appearances of taxa are reported from the Ust'Yudoma Formation (Nemakit-Daldynian Stage) and from the overlying Pestrotsvet Formation (TommotianAtdabanian stages) (Figs 4, 6). In the northern part of the Platform, the regional first occurrences are recorded from the Manykay, Medvezh'ya and Emyaksin 


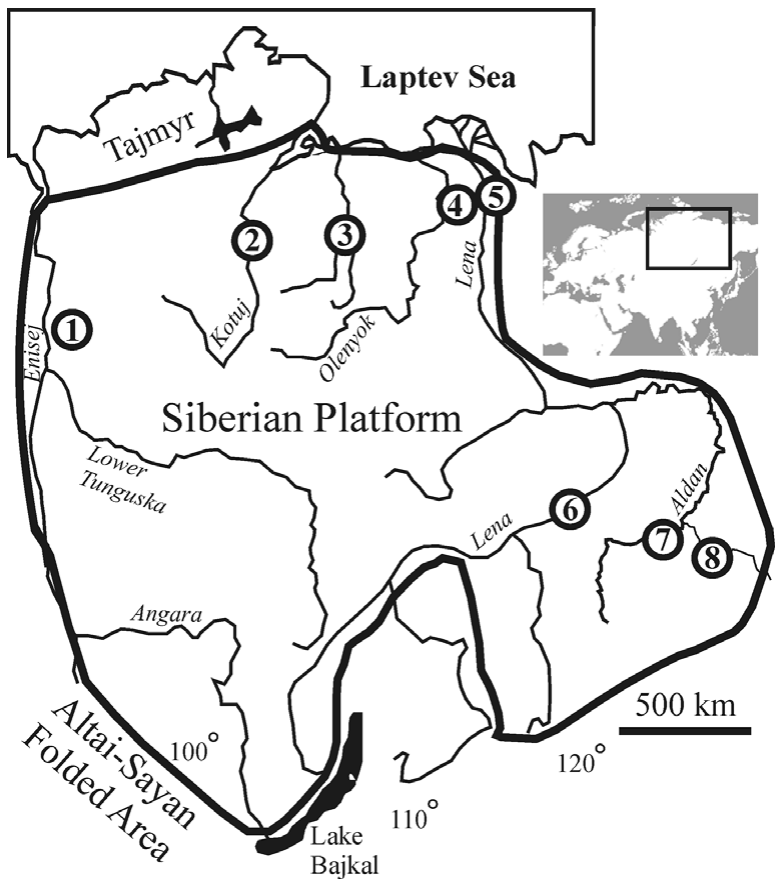

Figure 6. Map of the Siberian Platform with localities referred to in the main text and online Appendix 1 at http://journals.cambridge.org/geo. The localities are indicated by circles with the following numbers: 1 - Sukharikha River, middle reaches; 2 - Kotuj River (between the Sergej-KorilUoran rapids and mouth of the Kugda Brook) and the lowermost reaches of the Kotujkan River; 3 - Bol'shaya Kuonamka River, lower reaches; 4 - Olenyok River at the mouth of the Erkeket River and Khorbosuonka River at the mouth of the Mattajya River; 5 - Lena River, lower reaches, sections Chekurovka and at the mouth of the Ulakhan-Ald'yarkhaj Brook; 6 - Lena River, middle reaches, between sections Isit' and Achchagyi-KyyryTaas; 7 - Aldan River, between sections 'Dvortsy' and UlakhanSulugur; 8-Uchur-Maya region, sections along the Uchur River, between the Gonam and Selinde rivers, including the Mount 1291 m, Mount Konus, Nemnekey, and Selinde localities.

formations of the Anabar Uplift (Nemakit-DaldynianAtdabanian stages), upper Turkut and Kessyuse formations of the Olenyok Uplift (Nemakit-Daldynian-lower Tommotian), and uppermost Sukharikha-lower Krasny Porog formations abutting the lower Tommotian boundary on the northwestern margin of the Platform (Figs 4, 6). Detailed biostratigraphy and carbon isotope chemostratigraphy was obtained throughout these units and provides the basis for global correlations used herein (Fig. 4).

\section{2.b. Western Mongolia}

Ediacaran and lower Cambrian beds in Mongolia are better studied in sections of the Khasagt-Khairkhan Ridge in Western Mongolia, where carbon isotope chemostratigraphy and sequence stratigraphy are also available (Brasier et al. 1996; Esakova \& Zhegallo, 1996). This region represented an isolated Zavkhan Terrane that separated from Eastern Gondwana and collided with Siberia during the Ediacaran-Early Palaeozoic interval (Ruzhentsev \& Mossakovsky, 1995; Debrenne, Maidanskaya \& Zhuravlev, 1999;
Kheraskova et al. 2003). The chemostratigraphic record from this region is fragmentary because of thick intercalations of siliciclastic sediment from which the $\delta^{13} C_{\text {carb }}$ values cannot be read (Brasier et al. 1996). A composite section through the uppermost Tsagan Oloom and Bayan Gol formations in Western Mongolia is provided herein (Fig. 5).

\section{2.c. Kazakhstan}

The region was situated in proximity to East Gondwana and embraces Kazakhstanian terranes (Holmer et al. 2001; Popov et al. 2009). Among them, sections in the Lesser Karatau Range that include the Kyrshabakty and Chulaktau formations and the Shabakty Group in ascending order are the best studied and most continuous lower Cambrian sequences in Kazakhstan (Missarzhevsky \& Mambetov, 1981; Holmer et al. 2001). The Kyrshabakty and Chulaktau formations are biostratigraphically correlated, respectively, with the NemakitDaldynian and upper Nemakit-Daldynian-Tommotian stages of Siberia (Missarzhevsky \& Mambetov, 1981; Mambetov, 1993). First occurrences in members of the lower Shabakty Group are biostratigraphically correlated with the upper Atdabanian-Botoman stages of Siberia (Missarzhevsky \& Mambetov, 1981; Holmer et al. 2001).

\section{2.d. South China, India and Iran}

From the Yangtze Platform (South China), a set of the oldest first appearances of bilaterian taxa with mineralized skeletons is described herein mainly from the Zhujiaqing Formation of Yunnan and Maidiping Formation of Sichuan. They are correlated bio- and chemostratigraphically with the Nemakit-Daldynian Stage of Siberia (Qian et al. 2002; Li, Zhang \& Zhu, 2001; Li et al. 2007, 2009; Li \& Xiao, 2004; Steiner et al. 2007) and comprise in ascending order the assemblage zones Anabarites trisulcatusProtohertzina anabarica (SSF1) of the lower Meishucunian Stage, Paragloborilus subglobosus-Purella squamulosa (SSF2) and Watsonella crosbyi (SSF3) of the middle Meishucunian Stage (Steiner et al. 2007) (Fig. 3). The upper Meishucunian strata comprise the Sinosachites flabelliformis-Tannuolina zhangwentangi Assemblage Zone (SSF4) and directly underlie the trilobitic interval of the Cambrian in the shallow water realm of the Yangtze Platform. The first occurrences of skeletonized bilaterians within the Parabadiella and Eoredlichia-Wutingaspis zones of the Qiongzhusian Stage are biostratigraphically correlated (but not directly constrained by chemostratigraphy) with the middle-upper Atdabanian and upper Atdabanianlower Botoman stages of Siberia, respectively (Qian et al. 2002; Li, Zhang \& Zhu, 2001; Li et al. 2007; Li \& Xiao, 2004; Steiner et al. 2007; Fig. 3). This interval of earliest trilobitic zones is also more coarsely resolved by the Pelagiella subangulata Taxon Range Zone (SSF5) in the shallow water realm, roughly 
correlative with the Ninella tarimensis-Cambroclavus fangxianensis Assemblage Zone and the Rhombocorniculum cancellatum Taxon Range Zone at the northern margin of the Yangtze Platform. First appearances of skeletal fossils from sections of the upper Krol and lower Tal formations in the Lesser Himalayas of India and lower Soltanieh Formation in the Elburz Mountains of Iran are correlated with SSF1 of South China (Hamdi, Brasier \& Jiang, 1989; Hamdi, 1995; Hughes et al. 2005). The three regions belonged to East Gondwana (Fig. 1).

\section{2.e. Australia}

The first appearances of skeletal fossils in East Gondwana are also derived from South Australia. In the Arrowie Basin, first occurrences are documented herein from the lower Wilkawillina and Ajax Limestones, Wirrapowie Limestone and lower Mernmerna Formation, and the Moorowie Formation. These first appearances span the reportedly pre-trilobitic interval and Abadiella huoi-Pararia janeae zones, correlated biostratigraphically with the Atdabanian-Botoman stages of Siberia (Bengtson et al. 1990; Gravestock et al. 2001; Jago, Sun \& Zang, 2002; Jago et al. 2006; Skovsted, Brock \& Paterson, 2006; Topper et al. 2010, 2011). In the Stansbury Basin, the earliest skeletal fossils are derived from the Mount Terrible and Winulta formations, broadly correlated with the NemakitDaldynian-Tommotian stages of Siberia (Daily, 1976, 1990; Gravestock \& Shergold, 2001; Jago, Sun \& Zang, 2002; Jago et al. 2006). Other first occurrences from the overlying Kulpara Formation and Parara Limestone are reported from pre-trilobitic beds and Abadiella huoiPararia janeae zones (Bengtson et al. 1990; Gravestock et al. 2001; Jago, Sun \& Zang, 2002; Jago et al. 2006).

\section{2.f. Mediterranean region}

Several blocks now in North Africa and Western Europe were situated along the western margin of Gondwana (Fig. 1). Among these, first occurrences from the Corduban Series of central Spain are discussed herein. Based on biostratigraphic correlation with Morocco and chemostratigraphy, the Corduban Series represents a sub-trilobitic part of the lower Cambrian of Western Gondwana (Geyer \& Landing, 2004; Fig. 3). The first appearances from the lower Ovetian Stage in W Europe (Spain, France, Germany, Sardinia) are correlated biostratigraphically with those from the lower Issendalenian Stage in the Anti-Atlas Mountains of Morocco (Geyer \& Landing, 2004). The base of the Issendalenian Stage in Morocco correlates chemostratigraphically with the Delgadella anabara Zone of the Atdabanian Stage of Siberia (Kirshvink et al. 1991; Maloof et al. 2005, 2010a,b). First appearances of skeletal fossils from the upper Ludwigsdorf limestones of the Saxothuringian microcontinent (Germany) are correlated with the Atdabanian-Botoman stages of Siberia and the upper Qiongzhusian-lower Canglang- puian stages of South China (Elicki, 1994; Geyer \& Elicki, 1995).

\section{2.g. Avalonia}

The region formed a relatively small terrane of West Gondwanan affinity. In its portion represented by SE Newfoundland, the oldest first appearances are located within the Quaco Road Member of the upper Chapel Island Formation, within the Ladatheca cylindrica Zone of the Fortunian Stage and Watsonella crosbyi Zone of the Cambrian Stage 2 (Landing, 2004; Landing \& Westrop, 1998; Landing et al. 1989, 2007). Other important first occurrences are reported from the upper Cuslett and lower Fosters Point formations (Camenella baltica Zone, correlated with the lowermiddle Atdabanian Stage), as well as from the basal part of the overlying Brigus Formation (Callavia broeggeri Zone, correlated with the upper Atdabanian-Botoman stages) (Shergold \& Geyer, 2003; Fig. 3). In the portion of Avalonia represented by South Britain, the first occurrences regarded herein are from the Home Farm Member, Lower Comley Sandstone and Comley Limestone (Camenella baltica and Callavia zones).

\section{2.h. Laurentia}

In the Northwest Territories of Canada the first appearances are reported from the Ingta Formation of the Wernecke Mountains, correlated with the basal Cambrian Anabarites-Protohertzina Zone (Pyle et al. 2006) and underlain by the Precambrian-Cambrian boundary negative excursion (Narbonne, Kaufman \& Knoll, 1994; Pyle et al. 2004), and from the Sekwi Formation of the Mackenzie Mountains and basal Rosella Formation of the Cassiar Mountains, correlated with the Fallotaspis and Nevadella zones (Voronova et al. 1987; Dillard et al. 2007). In Greenland, important first occurrences are reported from the lower Buen Formation, biostratigraphically correlated with the Nevadella Zone and upper Atdabanian Stage (Conway Morris et al. 1987; Conway Morris, 1989; Debrenne \& Reitner, 2001; Conway Morris \& Peel, 2008, 2010), and from the upper Bastion-Ella Island formations, correlated with the Bonnia-Olenellus Zone and Botoman Stage (Skovsted, 2003, 2004, 2006). First occurrences in California and Nevada are from the Campito Formation, from the Fritzaspis, Fallotaspis and Nevadella zones (Durham, 1971; Hollingsworth, 2005, 2007; Fig. 3).

\section{2.i. Baltica}

The earliest skeletal fauna (Mobergella fauna) on the Baltic Shield known from the Kalmarsund Sandstone and subsurface deposits in southern Sweden is correlated with the Schmidtiellus mickwitzi Zone (Bengtson, 1968, 1970, 1977). First appearances from the Zawiszyn Beds of the upper Klimontovian Stage in Poland (Lendzion, 1972, 1978; 1983; Bengtson, 1977), Lükati Formation and lower part of the Tiskre Formation in 
northern Estonia are also attributed to the Schmidtiellus mickwitzi Zone of the Dominopol' Stage (Bergström, 1973; Mens \& Pirrus, 1977; Moczydłowska, 2002). These beds are broadly correlated with the Atdabanian Stage of Siberia (Moczydłowska, 2002). The oldest regional first occurrences are reported from the Lontova Formation in Estonia, Platysolenites antiquissimus Zone, broadly correlated with the Terreneuvian Series (Fig. 3).

\section{First appearances of mineralized skeletal parts in animal groups}

\section{3.a. Sponges and spongiomorphs}

The oldest fossils attributed to sponges are reported from the Cryogenian Period. One of the earliest lines of evidence for sponges comes from well-preserved molecular biomarkers of demosponges from strata of the Neoproterozoic Huqf Supergroup of the South Oman Salt Basin pre-dating the termination of the Marinoan glaciation and having a minimum age of c. $635 \mathrm{Ma}$ (McCaffrey et al. 1994; Love et al. 2006, 2009). Fossils interpreted as sponge-grade metazoans are also found in the pre-Marinoan Trezona Formation of South Australia with a maximum age of $659.7 \pm$ $5.3 \mathrm{Ma}$ (Maloof et al. 2010c). Palaeophragmodictya reticulata Gehling \& Rigby, 1996, from the Ediacaran Rawnsley Quartzite in South Australia, was interpreted as a hexactinellid (Gehling \& Rigby, 1996; Debrenne \& Reitner, 2001), or a stem-group sponge (Mehl, 1998), but later it was reinterpreted as an attachment disc of a problematic organism of uncertain affinity to sponges or cnidarians (Serezhnikova, 2007). The Late Ediacaran Fedomia mikhaili Serezhnikova \& Ivantsov, 2007 and Vaveliksia vana Ivantsov, Malahovskaya \& Serezhnikova, 2004, from the White Sea coast, are likely sponges (Ivantsov, Malahovskaya \& Serezhnikova, 2004; Serezhnikova, 2007; Serezhnikova \& Ivantsov, 2007).

\section{3.a.1. Demosponges and hexactinellids}

The earliest reported sponge spicules from c. $750 \mathrm{Ma}$ strata in Nevada were attributed to demosponges (Reitner \& Wörheide, 2002; Müller et al. 2007). Monaxonous thin-walled and hollow spicules of possible hexactinellids derive from Alaska (Allison \& Awramik, 1989; Debrenne \& Reitner, 2001), from beds inferred by chemostratigraphy to be Neoproterozoic, most likely pre-Varangerian (Kaufman, Knoll \& Awramik, 1992). Skeletal remains of sponges found in thin-sections from the Doushantuo Formation on the South China Platform are interpreted as demosponges, because they consist exclusively of siliceous monaxonal spicules $(\mathrm{Li}$, Chen \& Hua, 1998). Their maximum age is c. $580 \mathrm{Ma}$ (Condon et al. 2005). These latter, however, were regarded as possible pseudofossils (inorganic crystals) by Zhou, Yuan \& Xue (1998). Spicule-like objects of hexactinellid habit from the Ediacaran Doushantuo and Dengying formations of Hubei Province were observed in thin-section (Tang, Zhang \& Jiang, 1978; Zhao et al. 1988; Steiner et al. 1993), but these might also be pseudofossils composed of inorganic crystals (Zhou, Yuan \& Xue, 1998) or might instead represent acanthomorphic acritarchs (Zhang, Yuan \& Yin, 1998). Spicules with demosponge affinities are known from Cloudina reefs of Namibia (Reitner \& Wörheide, 2002), with an age of c. $550 \mathrm{Ma}$ (after Wood, Grotzinger \& Dickson, 2002; Grotzinger, Adams \& Schröder, 2005). Disarticulated and clustered tetracts, pentacts, hexacts and polyactines attributed to upper Ediacaran hexactinellids are preserved in iron oxides in chert layers of the upper Tsagan Oloom Formation of Western Mongolia (Brasier et al. 1996; Brasier, Green $\&$ Shields, 1997), but the stratigraphic position of strata yielding these spicules requires further age constraint. Hexactiniellid and/or demospongiid siliceous spicules were mentioned but not illustrated by Brasier \& Singh (1987, p. 326), Mazumdar \& Banerjee (1998) and Tiwari (1999). These fossils were recovered from the lowermost Cambrian basal Chert-Phosphate Member of the lower Tal Group, in the Mussoorie, Garwhal and Korgai synclines of the Lesser Himalayas and from the lower part of the Gangolihat Dolomite (Deoban Formation) of the Inner Kumaun Lesser Himalayas (inner carbonate belt) (Tiwari, Pant \& Tewari, 2000), correlated with the lowermost Cambrian (lower Meishucunian) based on the occurrence of protoconodonts (Azmi \& Paul, 2004).

Abundant and extraordinarily preserved hexactinellids and demosponges (including articulated specimens) are well documented from the early Cambrian deep basinal settings of the Yangtze Platform, from the Niutitang black shales of Hunan (Ding \& Qian, 1988; Steiner et al. 1993) and Hetang black shales of Anhui (Yuan et al. 2002). Hexactinellid sponge spicules occur in chert beds of the basal member of the Niutitang Formation of Hunan Province (Steiner et al. 1993: p. 6, figs 2-4) and of equivalent strata in Zhejiang Province (Steiner et al. 2004a, fig. 2h), of which the ages are constrained to the lower Meishucunian Stage owing to the occurrence of Kaiyangites. Megasters are not rare in the lower Meishucunian of Shaanxi Province (Steiner et al. 2007). By contrast, there are no remains interpreted as sponge spicules from the Meishucunian Stage in its stratotype area of eastern Yunnan (Rigby \& Hou, 1995), where the first spicules and sponge body fossils occur in the basal Yu'anshan Formation of the Qiongzhusian Stage (Steiner et al. 2001).

In Siberia, siliceous spicules attributed to the Hexactinellida are known from the lowermost Tommotian Nochorojcyathus sunnaginicus Zone (Sokolov \& Zhuravleva, 1983; Pel'man et al. 1990; Rozanov \& Zhuravlev, 1992) and traditionally referred to as Protospongia sp. (Protospongia Salter, 1864). Similar fossils have also been reported by Khomentovsky, Val'kov \& Karlova (1990) and Khomentovsky \& Karlova (1993) (but not illustrated) from the pre-Tommotian part of the lower Cambrian, from 
the upper Ust'-Yudoma Formation (Fig. 4; online Appendix 1 at http://journals.cambridge.org/geo). The earliest spicules of demosponges occur in the Fansycyathus lermontovae Zone of the upper Atdabanian Stage in northern Siberia (Fedorov in Shabanov et al. 1987; online Appendix 1 at http://journals.cambridge.org/geo). The earliest articulated hexactinellids and demosponges in Siberia occur in the lower Botoman Sinsk lagerstätten (Goryansky, 1977; Ivantsov et al. 2005; Ponomarenko, 2005; Rozanov et al. 2010; online Appendix 1 at http://journals.cambridge.org/geo).

\section{3.a.2. Calcareans}

The earliest calcarean sponge spicules of Dodecaactinella sp. occur in the lower Dokidocyathus regularis Zone of Siberia (Kruse, Zhuravlev \& James, 1995; Fig. 2). Pentactines of Sulugurella sulugurica Fedorov in Pel'man et al. 1990 were originally attributed to the Calcarea and reported from the Nochorojcyathus sunnaginicus Zone of the Tommotian (Pel'man et al. 1990) and from the probably slightly older uppermost Sukharikha Formation of the Sukharikha River section (Rowland et al. 1998), but their hexactinellid affinity is more plausible (A. Zhuravlev, pers. comm., 2008). Calcarean spicules are also known from the Atdabanian-Botoman-equivalent strata of Mongolia, Western Gondwana, Australia and Laurentia (online Appendix 1 at http://journals.cambridge.org/geo). The first articulated calcarean Gravestockia pharetronensis Reitner, 1992 occurs in Australian beds correlated with the Atdabanian Stage (Reitner 1992; Debrenne \& Reitner, 2001; online Appendix 1 at http://journals.cambridge.org/geo). According to Zhuravlev \& Wood (2008), spicules of first representatives of calcarean sponges are probably highmagnesium calcitic in original composition. Stemgroup sponges, which may combine mineralogy and morphology of calcarean and hexactinellid spicules, are also reported from the Cambrian Series 2 (Botting \& Butterfield, 2005; Harvey, 2010; see also Eiffelia Walcott, 1920 in online Appendix 1 at http://journals.cambridge.org/geo).

\section{3.a.3. Archaeocyaths and other probable aspicular sponges}

First archaeocyaths are known from the lowermost Tommotian Stage of the Siberian Platform (e.g. Rozanov et al. 1969, 1992, 2008; Shabanov et al. 2008; Riding \& Zhuravlev, 1995; Kruse, Zhuravlev \& James, 1995). Among them, an undetermined form is reported from the uppermost Ust'-Yudoma Formation (Rozanov et al. 1992; Shabanov et al. 2008), while several species occur in the basal Pestrotsvet Formation of the Lena-Aldan region (online Appendices 1 \& 2 at http://journals.cambridge.org/geo; Fig. 2). Archaeocyaths were also reported from the basal Pestrotsvet Formation at Selinde in the southeastern Siberian Platform (Korshunov, Repina \& Sysoev,
1969; Khomentovsky \& Karlova, 2002) and the uppermost Sukharikha Formation in the Igarka region of the northwestern margin of the Siberian Platform (Rozanov et al. 1969, but see Luchinina et al. 1997 and Rowland et al. 1998). In the latter two localities, carbonates display $\delta^{13} \mathrm{C}$ oscillations with high positive peaks characteristic of the lower Tommotian boundary beds, although the position of these peaks with respect to this boundary has been questioned (Kouchinsky et al. 2001, 2005, 2007). The skeleton of archaeocyaths is thought to have been originally mineralized with high-magnesium calcite (Zhuravlev \& Wood, 2008). The radiocyaths and cribricyaths are thought to be different groups of aspicular sponges with, respectively, aragonitic and high-magnesium calcitic biomineralization (Zhuravlev \& Wood, 2008). The radiocyaths first appear in the upper Tommotian of the Siberian Platform (Rozanov \& Zhuravlev, 1992), whereas the oldest cribricyaths are known from the Altai-Sayan Folded Area in the first half of the Atdabanian Stage (Rozanov \& Zhuravlev, 1992).

\section{3.b. Cnidariomorphs and problematic tubular forms}

Fossils that can be reasonably interpreted as diploblastic-grade metazoans with biomineralized skeletons are represented by a few but locally abundant forms in the upper Ediacaran strata (Grant, 1990; Grotzinger, Watters \& Knoll, 2000; Grotzinger, Adams \& Schröder, 2005; Wood, Grotzinger \& Dixon, 2002; Amthor et al. 2003; online Appendix 1 at $\mathrm{http}$ //journals.cambridge.org/geo). There is also a variety of mineralized solitary and modular calcareous corallomorphs in the lower Cambrian (Debrenne, Lafuste \& Zhuravlev, 1990). For convenience, all of these fossils are herein collectively termed cnidariomorphs, including such accretionarily growing mineralized solitary tube-like forms as anabaritids and protoconulariids. Hyolithelminths and 'coleolids' have a more uncertain biological affinity, and their interpretation as bilaterian organisms (such as annelids) cannot be excluded.

\section{3.b.1. Ediacaran calcified cnidariomorphs}

The earliest biomineralizing cnidariomorph fossils are represented by such solitary calcareous (probably aragonitic or high-magnesium calcite) tubular forms as Cloudina and Namacalathus (ECC in online Appendix 2 at http://journals.cambridge.org/geo and Fig. 2). Their lowermost occurrence is documented from the Nama Group in Namibia (Germs, 1972; Grant, 1990) and coincides with a pronounced positive carbon excursion reaching $8 \%$ and dated $548.8 \pm 1 \mathrm{Ma}$ (Grotzinger et al. 1995; Grotzinger, Watters \& Knoll, 2000; Condon et al. 2005; Grotzinger, Adams \& Schröder, 2005; Zhuravlev et al. 2011). Namapoikia rietoogensis Wood, Grotzinger \& Dixon, 2002 (a calcareous, probably aragonitic, modular form with a robust biomineralized but aspicular skeleton) is of 
uncertain affinity to sponges or cnidarians and occurs in the Nama Group of Namibia (Wood, Grotzinger \& Dixon, 2002) in the uppermost Ediacaran beds of the same estimated age.

\section{3.b.2. Corallomorphs}

The earliest solitary calcareous corallomorph, Cysticyathus tunicatus Zhuravleva, 1955, appears in the lower Dokidocyathus regularis Zone of the Tommotian Stage of the Siberian Platform, whereas the oldest modular corallomorphs are the khasaktiids Vittia Sayutina and Khasaktia Sayutina (Sayutina, 1980) from the upper Tommotian of Siberia (Rozanov \& Zhuravlev, 1992; Kruse, Zhuravlev \& James, 1995; online Appendices 1, 2 at http://journals.cambridge.org/geo). Khasaktiids are reconstructed as originally highmagnesium calcitic (Zhuravlev \& Wood, 2008). The oldest known korovinellid- or khasaktiid-like structures described from the uppermost Krol Formation (near the Precambrian-Cambrian boundary) of India (Flügel \& Singh, 2003; online Appendix 1 at http://journals.cambridge.org/geo) were interpreted as sponges/stromatoporoids (Flügel \& Singh, 2003), but their microbial origin was also suggested (Debrenne, Gangloff \& Zhuravlev, 1990).

\section{3.b.3. Anabaritids}

Anabaritids are a problematic early Cambrian group with originally calcareous, probably aragonitic, skeletons that typically had triradiate symmetry (Kouchinsky et al. 2009). Anabaritids mark the basal Cambrian strata in Siberia, Mongolia, Kazakhstan, China, India, Iran and Laurentia, but may also occur in the uppermost Ediacaran of Siberia (Karlova \& Vodanyuk, 1985; Karlova, 1987; Knoll et al. 1995) and Western Mongolia (Brasier et al. 1996; Esakova \& Zhegallo, 1996; Khomentovsky \& Gibsher, 1996; online Appendices 1, 2 at http://journals.cambridge.org/geo; Fig. 2).

\section{3.b.4. Protoconulariids}

Protoconulariids have a disputed affinity with Palaeozoic conulariids, a group most convincingly placed within the Cnidaria (Van Iten, Zhu \& Li, 2010). Calcium phosphatic protoconulariids first appear in the upper Anabarites trisulcatus-Protohertzina anabarica Assemblage Zone of the lower Meishucunian Stage of China. They are represented by Arthrochites emeishanensis Chen, 1982, Hexangulaconularia formosa $\mathrm{He}$ in Xing et al. 1984 and probably related forms, such as Carinachites spp. and Emeiconularia trigemme Qian et al. 1997 (Brasier, 1989a; Qian, 1989, 1999; Qian \& Bengtson, 1989; Conway Morris \& Chen, 1992; Qian, Li \& Zhu, 2001; Zhu et al. 2001; Qian et al. 2002; Steiner et al. 2004a). Hexangulaconularia formosa is also known from the Anabarites trisulcatus-Protohertzina anabarica Assemblage Zone of the Lesser Himalayas (Brasier \& Singh, 1987;
Hughes et al. 2005). A probably coeval occurrence of Carinachites sp. is described from the upper Ingta Formation in northwestern Canada (Laurentia), also assigned to the Anabarites trisulcatus-Protohertzina anabarica Zone (Pyle et al. 2006; online Appendices 1, 2 at http://journals.cambridge.org/geo; Fig. 2).

\section{3.b.5. Hyolithelminths}

Hyolithelminths have calcium phosphatic tubes that are circular (Hyolithellus Billings, 1871) or oval (Torellella Holm, 1893) in cross-section. They are similar to Sphenotallus Hall, 1847 and Byronia Matthew, 1899 also known from the Cambrian Series 2 and may be cnidarians as well, but do not show budding typical of the Cnidaria (Neal \& Hannibal, 2000; Van Iten, Zhu \& Collins, 2002; Van Iten et al. 2005; Peng et al. 2005). Hyolithelminths are alternatively compared to annelid tubes (Fisher, 1962; Sokolov \& Zhuravleva, 1983; Kiel \& Dando, 2009; Johnston et al. 2009; Skovsted \& Peel, 2011). Hyolithelminths are well known from the lower Tommotian Stage of Siberia (Rozanov et al. 1969; Sokolov \& Zhuravleva, 1983). Their first representatives are reported, but not illustrated, from the upper Purella Zone of the Nemakit-Daldynian Stage (Khomentovsky et al. 1983; Khomentovsky, Val'kov \& Karlova, 1990; Khomentovsky \& Karlova, 1993; Varlamov et al. 2008). Probably the earliest hyolithelminths are represented by Hyolithellus spp. from the Anabarites trisulcatus-Protohertzina anabarica Assemblage Zone of South China (Brasier, 1989a; Qian \& Bengtson, 1989; Qian, 1999; Qian et al. 2002), Ingta Formation of Laurentia (Pyle et al. 2006) and Lower Tal Formation of India (Brasier \& Singh, 1987; online Appendices 1, 2 at http://journals.cambridge.org/geo; Fig. 2).

\section{3.b.6. Problematic tubular forms}

Other widespread tubular problematics are represented by calcareous, probably aragonitic forms $\mathrm{Co}$ leolella Missarzhevsky in Rozanov et al. 1969, Coleoloides Walcott, 1889 and, possibly, Coleolus Hall, 1876 (to which 'Coleolus' trigonus Sysoev, 1962 is attributed; see online Appendix 1 at http://journals.cambridge.org/geo; Fig. 2). Coleoloides trigeminatus, Coleolella billingsi (Sysoev, 1962) and 'Coleolus' trigonus Sysoev, 1962 are reported from the lowermost Tommotian N. sunnaginicus Zone (Sokolov \& Zhuravleva, 1983) of Siberia. They also occur in probably older beds, where carbonates display high positive $\delta^{13} \mathrm{C}$ peaks, whose position with respect to the lower Tommotian boundary has been questioned (Kouchinsky et al. 2005, 2007). C. typicalis is known from the Tiksitheca licis Zone of Western Mongolia and Watsonella crosbyi Zone of Avalonia (Landing et al. 1989). Coleoloides is also reported from the Anabarites trisulcatus-Protohertzina anabarica Zone of India (Brasier \& Singh, 1987), but the material requires further revision. 


\section{3.c. Protoconodonts}

The protoconodonts are a group of phosphatic simplecone-shaped sclerites with a deep cavity, lamellar and often longitudinally fibrous wall, and with accretionary growth on the inner side and basal margin (Bengtson, 1976, 1977, 1983). Protoconodonts are microstructurally different from para- and euconodonts (see Section 3.q); finds of animals with grouped protoconodonts in the Chengjiang fossil lagerstätte (Chen \& Huang, 2002; Vannier et al. 2007) and partially articulated protoconodont apparatuses of lower Meishucunian species Mongolodus longispinus (Vannier et al. 2007) demonstrate their affinity with chaetognathans (Szaniawski, 1982, 2002; Hamdi, Brasier \& Jiang, 1989; Azmi, 1996; McIlroy \& Szaniawski, 2000; Doguzhaeva, Mapes \& Mutve, 2002; Azmi \& Paul, 2004; Qian et al. 2004; Pyle et al. 2006; Vannier et al. 2007; see also Remarks in section 'Protoconodonts' in online Appendix 1 at http://journals.cambridge.org/geo). The primary nature of phosphatization in protoconodonts has been questioned, however, because microstructures rather suggest that in analogy with grasping hooks of modern chaetognaths the protoconodonts had an organic composition, i.e. of hardened chitin (Steiner $\& \mathrm{Li}, 2010)$.

Among these fossils, Protohertzina anabarica and $P$. unguliformis (probably morphotypes within the same species collectively referred to as the Protohertzina anabarica group, e.g. by Brasier, 1989b) represent the earliest skeletal remains attributed to protoconodonts and, probably, bilaterian animals in general (Qian \& Bengtson, 1989). The first protoconodonts of the $P$. anabarica group appear in the Anabarites trisulcatus Zone of the Nemakit-Daldynian Stage on the Siberian Platform and in roughly contemporaneous beds in South China, India, Iran, Laurentia and probably Western Mongolia and Kazakhstan (online Appendices $1 \& 2$ at http://journals.cambridge.org/geo; Fig. 2). With the resolution of stratigraphic correlation available, it is not possible to warrant, however, their earlier appearance than the first calcareous sclerites and shells (see next Section).

\section{3.d. Molluscs, hyoliths, halwaxiids and chancelloriids}

Coiled, conical or cyrtoconic shells occur frequently in lower Cambrian faunas worldwide. These fossils resemble shells of undisputed molluscs in overall form and shell microstructure. It is largely accepted, therefore, that they are the earliest representatives of the Phylum Mollusca, falling more likely within its stem group (e.g. Peel, 1991; Budd, 2001). Univalved shells with solid walls (not composed of sclerites) presumably represent complete and adult external skeletons (but see Martí Mus, Palacios \& Jensen, 2008) and are considered herein to be molluscs. Some other problematic shells or plates, probably parts of multiplated chitonlike exoskeletons, may also belong to this group or to the Halwaxiida (see Section 3.k; online Appendices 1 \& 2 at http://journals.cambridge.org/geo).
The complete exoskeleton of hyoliths consists of a conical shell (conch), apertural lid (operculum) and may include a pair of curved retractable appendages (helens) protruding between the conch and operculum. These fossils are usually classified either within the Phylum Mollusca or Annelida, or in a separate phylumlevel group (e.g. Runnegar et al. 1975; Runnegar, 1980; Kouchinsky, 2000).

The Halwaxiida Conway Morris \& Caron, 2007 is an apparently monophyletic group that includes biomineralizing calcareous scale-bearing siphogonuchitids and halkieriids. Their compound scleritomes (= full set of sclerites of one individual, after Bengtson, 1985) could also contain conical shells (Bengtson, 1992a). Determining whether specific early Cambrian mollusclike shells represent the complete skeleton or only a part of the scleritome is not always straightforward (see Section 3.k and 'Other fossils' in online Appendix 1 at http://journals.cambridge.org/geo). Representatives of the Halwaxiida have been united with sedentary Chancelloriida in the problematic Coeloscleritophora, whose members share possession of hollow calcareous sclerites secreted at a fixed size by internal soft tissue and a similar skeletal microstructure (Bengtson \& Missarzhevsky, 1981; Bengtson \& Conway Morris 1992; Conway Morris \& Peel, 1995; Bengtson, 2005; Porter, 2008). Halwaxiids can be considered to be stem-group lophotrochozoans, while the general body morphology and affinity of chancelloriids is more problematic (Bengtson \& Hou, 2001; Janussen, Steiner \& Zhu, 2002; Randell et al. 2005; Bengtson, 2005; Sperling, Pisani \& Peterson, 2007; Porter, 2008).

These four groups (molluscs, hyoliths, halwaxiids and chancelloriids) appeared in the geological record at about the same time. Their evolutionary radiation in the earliest Cambrian was an important early step for metazoans, which gave rise to numerous forms typical of the lower Cambrian strata worldwide and dominated most of the pre-trilobitic bilaterian fossil assemblages. With the current fidelity of stratigraphic correlation available it is not yet possible to further resolve the relative order of first appearances of molluses, hyoliths and coeloscleritophorans (Fig. 2).

The oldest such fossils occur at the same level in the upper Anabarites trisulcatus-lower Purella zones of the Nemakit-Daldynian Stage of the southeastern Siberian Platform (Khomentovsky, Val'kov \& Karlova, 1990) correlated with the lowermost part of the rising trend in the lower Cambrian $\delta^{13} \mathrm{C}$ values, around feature $\mathrm{Z}$ of the Siberian $\delta^{13} \mathrm{C}$ reference scale (Brasier, Khomentovsky \& Corfield, 1993; Fig. 4). The fossils are represented by mollusc-like shells, such as cyrtoconic planispiral Oelandiella Vostokova, 1962 and sinistrally coiled Barskovia Golubev, 1976, conchs of hyoliths, siphogonuchitid sclerites and scaly shells of Purella Missarzhevsky, 1974. The earliest hyoliths are also described from the probably time-equivalent basal Purella Zone of Western Mongolia (Khomentovsky \& Gibsher, 1996), SSF1 of South China (Qian \& Bengtson, 1989; Steiner et al. 2004a) and India (Brasier \& Singh, 
1987; Hughes et al. 2005). Siphogonuchitid sclerites and shells of Maikhanella Zhegallo in Voronin et al. 1982 are also reported from SSF1 beds of South China (Qian \& Bengtson, 1989; Steiner et al. 2004a), whereas Purella defines the base of the Purella Zone in Western Mongolia (Khomentovsky \& Gibsher, 1996; Fig. 5).

The earliest confirmed appearance of Chancelloria is represented by articulated sclerites from the Purella Zone of the Nemakit-Daldynian Stage of Siberia (Khomentovsky, Val'kov \& Karlova, 1990) and correlated with a trough between Siberian isotopic features Z and I (Brasier, Khomentovsky \& Corfield, 1993; Fig. 4). Identification of fossils reported as single rays of Chancelloria sp. from the Anabarites trisulcatus and basal Purella zones of the Nemakit-Daldynian Stage of the southeastern Siberian Platform (Khomentovsky, Val'kov \& Karlova, 1990; Khomentovsky \& Karlova, 2005; Brasier, Khomentovsky \& Corfield, 1993) is questionable (Zhuravlev et al. 2011). Likewise, the occurrence of Chancelloriidae in SSF1 of South China (Qian \& Bengtson, 1989) has not been confirmed (M. Steiner, unpub. obs.; Online Appendix 1 at http://journals.cambridge.org/geo). Single-rayed sclerites of Cambrothyra are known, however, from SSF1. This organism is treated as closely related to, but outside the Chancelloridae sensu stricto (Steiner et al. 2004a, fig. 2; Moore et al. 2010).

\section{3.e. Cambroclavids and paracarinachitids}

Cambroclaves are originally calcareous (probably aragonitic) sclerites without concentrically arranged growth increments and consist of a basal hollow shield usually bearing a spine (Qian, 1978; Mambetov \& Repina, 1979; Bengtson et al. 1990; Conway Morris \& Chen, 1991; Conway Morris et al. 1997; Elicki \& Wotte, 2003). Paracarinachitids are probably related forms, but were formed by overlapping growth increments (Qian \& Bengtson, 1989). These fossils are regarded as protective sclerites of bilaterally symmetrical animals without reliable systematic position (Bengtson et al. 1990). They were alternatively interpreted as receptaculitids (algae or sponges) (Dzik, 1994), protoconodonts (Mambetov \& Repina, 1979), acanthocephalans (Qian \& Yin, 1984) or such ecdysozoan groups as priapulids (Conway Morris et al. 1997) and lobopodians (Qian, 1999; Liu et al. 2007). A fragment of an articulated body covered with cambroclavid-type sclerites was reported from the Sirius Passet fauna and has been tentatively assigned to the Ecdysozoa (Conway Morris \& Peel, 2010). The fibrous ultrastructure of the wall in cambroclavids and paracarinachitids (Qian \& Bengtson, 1989; Conway Morris \& Chen, 1991), typical of the other calcareous fossils discussed above, such as molluscs, hyoliths, halwaxiids and chancelloriids, are nevertheless compatible with a lophotrochozoan affinity.

The first sclerites of cambroclavids (Zhijinites Qian, 1978) and paracarinachitids (Paracarinachites Qian \& Jiang in Luo et al. 1982) are known from the Yangtze Platform, Paragloborilus subglobosus-
Purella squamulosa Assemblage Zone (SSF2) of the middle Meishucunian Stage, marked by a rising trend in the carbon isotope record below a prominent positive peak ZHUCE (Qian, 1999; Qian et al. 2002; Qian \& Bengtson, 1989; Bengtson, 1992b; Steiner et al. 2007; online Appendices $1 \& 2$ at http://journals.cambridge. org/geo; Fig. 2).

\section{3.f. Tommotiids}

Tommotiids are represented by calcium phosphate sclerites with evidence of basal marginal accretionary growth. These fossils have been interpreted as sclerites of larger scleritomes of problematic animals (Bengtson, 1970, 2004; Holmer et al. 2008; Skovsted et al. 2008, $2009 \mathrm{~b}$ ). The taxonomy of tommotiids was discussed by Landing (1984, 1995), Bengtson (1986), Laurie (1986), Bengtson et al. (1990), Conway Morris \& Chen (1990), Esakova \& Zhegallo (1996) and Skovsted et al. (2009a). Based on the organophosphatic shell composition and morphological similarities, tommotiids have been regarded as closely related to brachiopods (Williams \& Holmer, 2002). Recent discoveries of articulated tommotiids show distinct affinities to lophophorates, including a sessile habit and brachiopod-like shells within the scleritome (Skovsted et al. 2008, 2009b; Holmer et al. 2008).

Classical tommotiids, such as Camenella Missarzhevsky in Rozanov \& Missarzhevsky, 1966, occur in the basal Tommotian Stage deposits of the southeastern Siberian Platform (Rozanov et al. 1969). Without description or illustration, they are also reported from apparently older beds of the northern Siberian Platform (Fedorov \& Shishkin, 1984; Khomentovsky \& Karlova, 1993; Luchinina et al. 1997; Meshkova et al. 1976; Rozanov et al. 1969). These beds contain pre-Tommotian prominent positive carbon isotopic peaks (Kouchinsky et al. 2001, 2007; Fig. 4; online Appendices $1 \& 2$ at http://journals.cambridge.org/geo). Probably the earliest appearance of Camenella is that reported from Western Mongolian beds at the beginning of the rising trend towards positive peak $\mathrm{D}$ (Brasier et al. 1996, fig. 9; Fig. 5), which may correspond to the rising trend towards Siberian peaks I or I' (Fig. 4).

Porcauricula hypsilippis (Jiang, 1980) is known from lower SSF2 beds (Qian \& Bengtson, 1989), in the rising trend towards a prominent positive peak ZHUCE in China (Brasier et al. 1990; Li et al. 2009). Lapworthella ludvigseni Landing, 1984 and Eccentrotheca kanesia Landing, Nowlan \& Fletcher, 1980 occur in the lower Watsonella crosbyi Zone of SE Newfoundland (Landing et al. 1989). Hence, the first tommotiids reported from Western Mongolia, South China and Avalonia are probably older than those from the base of the Tommotian Stage in its stratotype in the southeastern part of the Siberian Platform (online Appendices 1 $\& 2$ at http://journals.cambridge.org/geo; Fig. 2).

\section{3.g. Tianzhushanellids}

Tianzhushanellids are bivalved and probably originally aragonitic shelly fossils assigned to the Family 
Tianzhushanellidae Conway Morris in Bengtson et al. 1990 with uncertain higher-rank taxonomy (see 'Other fossils' in Online Appendix 1 at http://journals.cambridge.org/geo). They were referred to molluscs (Parkhaev, 1998), but have more recently been regarded as the best candidates for calciticshelled stem-group brachiopods (Balthasar, 2008; Li, 2009). New articulated material of Apistoconcha from strata correlative with the Cambrian Stage 3 in Australia seems to support its stem-group brachiopod position (Skovsted et al. 2010). The earliest undoubted representatives of the group are known from the SSF3 of China (Qian, 1999; Li \& Chen, 1992; Steiner et al. 2007) and occur at near the peak of the positive carbon isotope excursion ZHUCE in Sichuan (Brasier et al. 1990, fig. 6; online Appendices 1 \& 2 at http://journals.cambridge.org/geo; Fig. 2).

\section{3.h. Brachiopods}

The earliest reported brachiopod species with a calcium phosphate (organophosphatic) shell is the paterinid Aldanotreta sunnaginensis Pel'man, 1977. It first appears on the Siberian Platform in the N. sunnaginicus Zone of the Tommotian Stage (Bengtson et al. 1987; Ushatinskaya \& Malakhovskaya, 2001; online Appendices $1 \& 2$ at http://journals.cambridge.org/geo; Figs 2, 4). The earliest Siberian brachiopod with a calcareous shell is Nochoroiella isitica Pel'man in Grigor'eva, Melnikova \& Pel'man, 1983 (assigned to obolellids, although its affinity with brachiopods was questioned: see online Appendices $1 \& 2$ at http://journals.cambridge.org/geo) and Obolella sp. from the D. lenaicus Zone of the Tommotian Stage (Figs 2,4). Chemostratigraphic correlation with Siberia (cf. Brasier et al. 1996) suggests that these occurrences are likely pre-dated by Khasagtina primaria Ushatinskaya, 1987 from Western Mongolia. The latter fossil is originally assigned to kutorginids, but its affinity to brachiopods needs revision (online Appendices $1 \& 2$ at http://journals.cambridge.org/geo; Figs 2, 5).

\section{3.i. Stenothecoids}

Stenothecoids, a group of probably low-magnesium calcite (Zhuravlev \& Wood, 2008) enigmatic bivalved organisms with serial paired imprints sometimes present, occur in Cambrian Series 1-3 (Aksarina, 1968; Yochelson, 1969; Runnegar \& Pojeta, 1974; Rozov, 1984; Pel'man, 1985; online Appendices 1 \& 2 at http://journals.cambridge.org/geo). In Siberia, the first reliable stenothecoids appear in the late Tommotian Stage of the Altai-Sayan Folded Area (Pel'man et al. 1992; Rozanov \& Zhuravlev, 1992), but the earliest stenothecoids overall (Stenothecoides sp. and S. yochelsoni) are reported respectively from Western Mongolia (Voronin et al. 1982; Khomentovsky \& Gibsher, 1996, fig. 13; Fig. 5; online Appendices 1 \& 2 at http://journals.cambridge.org/geo) and the SSF3 Zone of South China (Yu, 1996; online Appendices 1 \&
2 at http://journals.cambridge.org/geo). Voronin et al. (1982) defined the Stenothecoides Zone in Western Mongolia at a level correlated chemostratigraphically (cf. Brasier et al. 1996; Fig. 5) with prominent positive peaks of the uppermost Nemakit-Daldynian Stage of the Siberian Platform. Consequently, like brachiopods, the first stenothecoids are reported from Cambrian Stage 2, probably below the lower Tommotian boundary (Fig. 2).

\section{3.j. Mobergellids}

Mobergellids are low conical or disc-shaped calcium phosphate problematic fossils with evidence of accretionary growth and paired radiating (possibly, muscular) imprints on the interior side (Bengtson, 1968; Conway Morris \& Chapman, 1997; Skovsted, 2003; Dzik, 2010). The first occurrence of Mobergella sibirica Skovsted, 2003 (formerly Mobergella radiolata Bengtson, 1968) in Siberia is known from the lower Dokidocyathus lenaicus-Tumuliolynthus primigenius Zone of the Tommotian Stage (Rozanov et al. 1969; Sokolov \& Zhuravleva, 1983; Rozanov \& Sokolov, 1984; Missarzhevsky, 1989; Rozanov \& Zhuravlev, 1992; online Appendices 1 \& 2 at http://journals.cambridge.org/geo; Fig. 4). Mobergella sp. is also reported from the upper $D$. regularis Zone of the Tommotian Stage (Repina et al. 1974), but was not illustrated. Fossils described as Mobergella, but without characteristic radiating imprints, are known from the middle Meishucunian Stage of China (Li et al. 2007; online Appendix 1 at http://journals.cambridge.org/geo), although no definite record of mobergellids exists from China (Qian \& Bengtson, 1989; Streng \& Skovsted, 2006). The most reliable first appearance of the group is thus in the lower D. lenaicus Zone of the Tommotian Stage (upper part of the Cambrian Stage 2), within the carbon isotope trough between peaks III and IV of the Siberian reference scale (Brasier et al. 1994a,b; online Appendices 1 \& 2 at http://journals.cambridge.org/geo; Figs 2, 4).

\section{3.k. Other problematic shells and sclerites}

Besides shells assigned herein to molluscs, hyoliths, halwaxiids, brachiopods, mobergellids, stenothecoids and tianzhushanellids, there are shells or plates of a calcareous or unknown original composition, often with evidence of accretionary growth. Some of these may represent parts of scleritomes similar to those of halkieriids or chitons (Conway Morris, McIlroy \& Rushton, 1998; Vendrasco et al. 2009; see 'Molluscs' and 'Other fossils' in online Appendix 1 at http://journals.cambridge.org/geo). A number of such problematic shells are reported from China, where they are found in beds of the middle Meishucunian Stage (Bengtson, 1992b; Li et al. 2007). Most of them are treated as problematic molluscs by Bengtson (1992b) and Li et al. (2007), but some forms among 
them are alternatively regarded as 'brachiopod-like' or 'problematic brachiopods' by Qian, Li \& Zhu (2001).

An array of problematic sclerites from Cambrian Series 1-2 is known from Siberia and elsewhere, and some of the sclerites can be assigned to larger groups discussed herein, such as protoconodonts, chancelloriids, halwaxiids, tommotiids and cambroclavids or to ecdysozoan cuticular sclerites and fragments of carapaces, but the others are more problematic (see Bengtson, 1992b; Qian et al. 2004; Li et al. 2007; see 'Other fossils' in online Appendix 1 at http://journals.cambridge.org/geo).

\section{3.l. Trilobites}

The Class Trilobita are advanced arthropods (Phylum Arthropoda) with calcareous (low-magnesium calcite) carapaces (Wilmot \& Fallick, 1989). The first occurrences of trilobites in the world (highlighted by thick horizontal lines within Stage 3 interval in Fig. 3) post-date or are estimated to be no earlier than those on the Siberian Platform, where their first undoubted appearance is just above the base of the Atdabanian Stage (Lieberman, 2002; Hollingsworth, 2005, 2007, 2008; online Appendices $1 \& 2$ at http://journals.cambridge.org/geo; Fig. 2). The earliest trilobites (Family Archaeaspididae, Order Redlichiida) are represented by Profallotaspis Repina in Khomentovsky \& Repina, 1965 from Siberia and Fritzaspis Hollingsworth, 2007 from Laurentia.

\section{3.m. Bradoriids}

Bradoriids known from Cambrian to lower Ordovician rocks worldwide have originally weakly or secondarily mineralized (phosphatized) carapaces (Jones \& McKenzie, 1980; Landing, 1980; Butterfield, 2003; Zhang, 2007; Zhang, Dong \& Maas, 2011). These arthropods are represented by the Order Bradoriida Raymond, 1935 (Bradoriida sensu stricto) and Phosphatocopida Müller, 1964 (Hou et al. 2002; Maas \& Waloszek, 2005; Williams et al. 2007; Zhang, 2007). The former are regarded at present as stemgroup crustaceans, whereas the latter are considered by some to be crown-group crustaceans (Hou et al. 1996, 2010; Shu et al. 1999). Although other stemgroup crustaceans represented by non-mineralizing Isoxys zhurensis Ivantsov, 1990 are known as early as the middle Profallotaspis jakutensis Zone of the Atdabanian Stage on the southeastern Siberian Platform (Ivantsov, 1990), the first bradoriid Cambria Neckaja \& Ivanova, 1956 is reported in Siberia from the middle Atdabanian Delgadella anabara Zone (online Appendices $1 \& 2$ at http://journals.cambridge.org/geo; Figs 2, 4). Coeval first occurrences of bradoriids are also known from South China (Hou et al. 2002), Gondwana (Hinz-Schallreuter, Gozalo \& Liñán, 2008; Topper et al. 2011), Avalonia (Brasier, 1989c) and Baltica (Streng, Ebbestad \& Moczydłowska, 2008).

\section{3.n. Lobopodians}

Lobopodians have been considered a Cambrian stem group of the Panarthropoda, including such phyla as Onychophora, Tardigrada and Arthropoda (see Budd, 1997; Liu et al. 2007; Edgecombe, 2009). These animals were similar to modern onychophorans and are often regarded as members of the Phylum Lobopodia Snodgrass, 1938 (Hou \& Bergström, 1995) or Tardipolypoda Chen \& Zhou, 1997. Exceptionally preserved in the Chengjiang fossil lagerstätte, they are elongate animals with paired limbs and sclerites (trunk plates) situated along each side of the body (Chen, Hou \& Lu, 1989; Chen, Zhou \& Ramsköld, 1995; Ramsköld \& Hou, 1991; Bergström \& Hou, 2001; Hou et al. 2004). The sclerites are thought to be of an original calcium phosphatic composition, although their biomineralization has been doubted by Steiner et al. (2007).

The first sclerites of Microdictyon sp. in Siberia are reported herein from the Emyaksin Formation of the Bol'shaya Kuonamka River, from beds correlated by carbon isotope chemostratigraphy with the upper Delgadella anabara Zone of the Atdabanian Stage (Kouchinsky et al., unpub. data; online Appendices $1 \& 2$ at http://journals.cambridge.org/geo; Fig. 2). This occurrence is somewhat older than the previously reported occurrence from the upper Atdabanian Fansycyathus lermontovae Zone of Lena River (Varlamov et al. 2008). It is correlated chemostratigraphically (Dillard et al. 2007; online Appendices $1 \& 2$ at http://journals.cambridge.org/geo) with the regional first occurrence of Microdictyon sp. and Microdictyon cf. rhomboidale Bengtson, Matthews \& Missarzhevsky, 1986 in the lower Nevadella Zone of Laurentia (Bengtson, Matthews \& Missarzhevsky, 1986; Voronova et al. 1987; Fig. 3) and, probably, with the first occurrence of M. sphaeroides Hinz, 1987 in the Camenella baltica Zone of Avalonia (Hinz, 1987) and Microdictyon depressum Bengtson in Bengtson et al. 1990 in the Abadiella huoi Zone of Australia. The first soft-bodied lobopodians with remains of sclerites are already diverse and well known from the Chengjiang fossil lagerstätte, which is time-equivalent with the upper Atdabanian Stage of Siberia.

\section{3.o. Palaeoscolecids}

The Class Palaeoscolecida Conway Morris \& Robison, 1986 is known from the Cambrian Series 2 to the Upper Silurian. These fossils are morphologically similar to nematomorphs (Hou \& Bergström, 1994) and priapulids (Conway Morris, 1997). They are broadly considered as a stem group of the Priapulida (Harvey, Dong \& Donoghue, 2010) or Cycloneuralia (Budd, 2001; Conway Morris \& Peel, 2010). Complete preservation of their worm-like bodies is known, but far more often they occur as disarticulated calcium phosphate cuticular sclerites. The first palaeoscolecids, represented by the biomineralized trunk sclerites 
Hadimopanella apicata Wrona, 1982 are reported herein from the middle Nochoroicyathus kokoulini Zone (lower Judomia Zone) of northern Siberia (Kouchinsky et al., unpub. data; online Appendices 1 \& 2 at http://journals.cambridge.org/geo; Figs 2, 4). The earliest soft-bodied preservation of palaeoscolecids is known from the Sirius Passet fauna of Laurentia (Greenland; Conway Morris \& Peel, 2010; online Appendices $1 \& 2$ at http://journals.cambridge.org/geo) and the Chengjiang fossil lagerstätte of South China (Hu, 2005), which are time-equivalent with the upper Atdabanian of Siberia.

\section{3.p. Echinoderms}

The earliest fossils of the phylum Echinodermata are disarticulated and presumably originally highmagnesium calcite plates (Dickson, 2002, 2004). Some of these plates derive from brachiole-bearing echinoderms and thus can be assigned to eocrinoids. The 'class' Eocrinoidea Jaekel, 1918 is paraphyletic and comprises stem-groups of other blastozoan clades (e.g. Sprinkle, 1973). The earliest echinoderm plates like these are reported herein from the upper Delgadella anabara Zone of the Atdabanian Stage from Siberia (Kouchinsky et al., unpub. data; Zamora et al. in press; online Appendices 1 \& 2 at http://journals.cambridge.org/geo; Figs 2, 4). First echinoderm plates from the lower part of the Nevadella Zone of Laurentia are chemostratigraphically correlated with the upper part of the Delgadella anabara Zone of Siberia (Dillard et al. 2007; Fig. 3). The earliest isolated echinoderm plates occur in lower Ovetian beds of West Gondwana (Spain) broadly correlated with the Delgadella anabara Zone of Siberia and also appear contemporaneously in South China and Australia (Zamora et al. in press).

\section{3.q. Chordates (paraconodonts and agnathans)}

Conodonts (including para- and euconodonts) are characterized by calcium phosphatic dental structures with dentin-like tissue (but see Kemp, 2002a,b). They are regarded as the earliest known biomineralized chordates (Donoghue, Forey \& Aldridge, 2000; Donoghue, Sansom \& Downs, 2006). There is a microstructural similarity between the two sub-groups as well as a histological and morphological transition from paraconodonts to euconodonts, and therefore they are united as conodonts (Szaniawski \& Bengtson, 1993, 1998).

The oldest paraconodonts from Siberia are Westergaardodina cf. tricuspidata Müller, 1959 and Furnishina sp. from the Paibian Stage-equivalent Kutugunian Horizon, which contains the upper Cambrian (Furongian Series) SPICE carbon isotope excursion (online Appendices 1 \& 2 at http://journals.cambridge.org/geo; Shabanov et al. 2008). Furnishina and Westergaardodina are known, however, from the Drumian Stage (within the Cambrian Series 3, or traditional Middle Cambrian) in most other crustal units. The oldest paraconodonts, represented by Furnishina sp. and Westergaardodina sp., are reported respectively from the Triplagnostus gibbus Zone of the uppermost part of Cambrian Stage 5 (lower Series 3) in Sweden (Müller, 1959, 1971; Dong, 2004) and from Stage 5 deposits of Alaska (Dutro et al. 1984), but the former is much better preserved and constrained stratigraphically.

The earliest vertebrates with ossification in the dermal skeleton, that contains dentin-like tissue (Smith, Sansom \& Repetski, 1996; Karatajute-Talimaa, 1997), are similar to the Ordovician agnathans and represented by disarticulated calcium phosphatic plates of Anatolepis sp. from the mid-Sunwaptan Stage of Laurentia (Smith \& Sansom, 1995; Smith, Sansom \& Cochrane, 2001) corresponding to the upper part of the Cambrian Stage 9 (Furongian Series).

\section{Discussion}

There is no unambiguous evidence of the existence of bilaterian superphyla in the Precambrian (Budd, 2008; Budd \& Jensen, 2000, 2003), although some bilaterally symmetrical forms from the late Ediacaran, younger than $555 \mathrm{Ma}$, are interpreted as their representatives (e.g. Fedonkin \& Waggoner, 1997). On the other hand, Ediacara-type fossils have repeatedly been reported from the Early Palaeozoic (Conway Morris, 1993; Jensen, Gehling \& Droser, 1998; Samuelson, Van Roy \& Vecoli, 2001; Zhang \& Babcock, 2001), but none of those is comparable with typical Ediacaran vendobionts in their structure, symmetry and growth pattern (Antcliffe \& Brasier, 2008; Zhuravlev et al. 2011).

The general succession of first appearances of biomineralized skeletal parts during the Cambrian radiation includes two main sets clustered geochronologically by high-rank phylogeny and reflects two successive phases of diversification of bilaterians (Fig. 2). Such a pulsed diversification accompanied a general increase in generic diversity of the biota towards the early Botoman maximum preceding the Botoman-Toyonian biotic crisis (Brasier et al. 1994a; Zhuravlev \& Wood, 1996; Zhuravlev, 2001; Li et al. 2007).

The first phase recognized herein is marked by a set of first appearances of biomineralization in the Terreneuvian Epoch (c. 541-521 Ma), mainly within the Fortunian Age. The latter embraces the first c. $10 \mathrm{Ma}$ of the Cambrian Period (Fig. 2). During the Terreneuvian Epoch such major skeletal groups as protoconodonts, halwaxiids, chancelloriids, hyoliths, molluscs, tommotiids, brachiopods, tianzhushanellids, stenothecoids, cambroclavids-paracarinachitids and mobergellids first appeared and diversified, as well as other forms with problematic affinities to these groups (online Appendices $1 \& 2$ at http://journals.cambridge.org/geo; Fig. 2). All of them, except protoconodonts and possibly chancelloriids, can be comfortably placed within the total-group Lophotrochozoa. Among them, such extant biomineralizing lophotrochozoan phyla as Mollusca and Brachiopoda can be recognized. Annelida does not have undisputed biomineralized 
representatives during the Cambrian radiation (Conway Morris \& Peel, 2008), but such problematic groups as hyolithelminths, hyoliths and halwaxiids may share that affinity (see Section 3 and remarks in online Appendix 1 at http://journals.cambridge.org/geo). By contrast, Bryozoa certainly appear relatively late, in the uppermost Cambrian, at the onset of the Ordovician radiation (Landing, English \& Keppie, 2010).

Protoconodonts were among the first bilaterians to acquire hardened (probably mineralized calcium phosphatic) skeletal parts (presumably for active predation). These have been interpreted as grasping spines of the Chaetognatha, a protostomian phylum close to the Lophotrochozoa, but most likely its sister-group (Halanych, 2004; Dunn et al. 2008). They appeared in the fossil record at about the same time as the first calcareous sclerites of coeloscleritophorans, shells of molluscs and hyoliths. The majority of bilaterian skeletal fossils of the Terreneuvian Series belong to these latter groups. Their first appearances occurred in beds younger than the Precambrian-Cambrian boundary and the carbon isotope negative anomaly associated with this boundary (Narbonne, Kaufman \& Knoll, 1994; Brasier et al. 1996; Kimura et al. 1997; Li et al. 2009), but not younger than those with Siberian $\delta^{13} \mathrm{C}$ feature $\mathrm{Z}$ and attributed to the upper Anabarites trisulcatus-lower Purella zones of the NemakitDaldynian Stage (Brasier, Khomentovsky \& Corfield, 1993; Brasier, et al. 1994a,b). These first appearances can be correlated with the Anabarites trisulcatusProtohertzina anabarica (SSF1) Assemblage Zone of the lower Meishucunian Stage of South China, where all of them except shells of molluscs occur in beds older than the tuffite with a combined depositional age of $535.2 \pm 1.7 \mathrm{Ma}$ (Zhu et al. 2009).

Calcium phosphatic sclerites of tommotiids, probably members of the stem group of organophosphatic brachiopods, have a younger first appearance associated with the same rising trend, but still below highly positive peaks of the lower part of the Cambrian Stage 2. The first reported appearance of tommotiids is older than the estimated c. $530 \mathrm{Ma}$ base of the Cambrian Stage 2 in Avalonia (Landing et al. 2007). Such groups as cambroclavids-paracarinachitids, other problematic shells with affinities close to molluscs or halwaxiids, and some problematic sclerites also appear during this interval (online Appendices 1 \& 2 at http://journals.cambridge.org/geo; Fig. 2).

Brachiopods, apparently related to tommotiids, are another major group of lophotrochozoan animals with their first appearance in the Cambrian Stage 2. Together with tianzhushanellids, which probably represent stemgroup calcareous brachiopods, and stenothecoids, their first occurrences are registered from Stage 2 strata older than or coeval with the Nemakit-DaldynianTommotian boundary of $c .525 \mathrm{Ma}$ (Maloof et al. 2010a,b). Mobergella, Rhombocorniculum and some other problematic sclerites appeared during the upper part of Cambrian Stage 2 (online Appendices $1 \& 2$ at http://journals.cambridge.org/geo; Fig. 2).
Biomineralization in ecdysozoans and deuterostomians did not apparently occur during the first phase of the early Cambrian bilaterian radiation, but these events mark the second phase. Non-biomineralized ecdysozoans, however, existed before, as evidenced by: (1) fossilized embryos of Markuelia secunda Val'kov from the basal Tommotian Stage in Siberia, having already a sclerotized cuticle and representing the Scalidophora, a sub-group of the Cycloneuralia (Bengtson \& Yue, 1997; Dong et al. 2004, 2005, 2010); embryos and possibly related larvae of Pseudooides prima from the lower Meishucunian Stage of South China, considered as possible stem-group arthropods (Steiner et al. 2004b) and (2) the arthropod-type trace fossils in pre-trilobitic strata (Crimes, 1987; Weber \& Zhu, 2003; Weber, Steiner \& Zhu, 2007).

The second phase of the early Cambrian bilaterian radiation is thus marked by the first appearances of biomineralization in the Superphylum Ecdysozoa within Cambrian Stage 3, during $<5 \mathrm{Ma}$ (Fig. 2). The earliest undoubted and widespread event in the second phase is the appearance of calcification in carapaces of trilobites at the base of Stage 3, succeeded by the first appearances of calcium phosphate carapaces of bradoriids (Phylum Arthropoda), sclerites of lobopodians (Phylum Tardipolypoda) and palaeoscolecids (?Phylum Priapulida) in that order, in the early and middle parts of Stage 3 (online Appendices 1 \& 2 at http://journals.cambridge.org/geo; Fig. 2). The diversity of ecdysozoans and their dominance in the Burgess Shale-type fossil communities in upper Stage 3 , by the conclusion of the Cambrian radiation, is well documented in such fossil lagerstätten as the Sirius Passet of north Greenland and the roughly timeequivalent Chengjiang of South China (e.g. Conway Morris \& Peel, 2008, 2010).

The second phase also involves the Superphylum Deuterostomia, Phylum Echinodermata. The earliest biomineralizing representatives of echinoderms appear in the middle of Stage 3. Among them eocrinoids, members of the stem-group Echinodermata, can be recognized. The origin of their high-magnesium calcite stereom skeleton is the first documented skeletal biomineralization event among deuterostomians. Tunicates (Phylum Chordata) may have also existed at that time (Chengjiang fauna, Chen et al. 2003, but see Bergström, 2010), and some of them may have produced biomineralized spicules (see Bengtson et al. 1990). Non-mineralizing representatives of the Phylum Chordata were also present during the Cambrian radiation: hagfish-like fossils from Chengjiang are most likely the first vertebrates, but without traces of biomineralization (Shu et al. 1999; Conway Morris, 2006; Bergström, 2010). The first appearances of calcium phosphatic dental mineralization in problematic chordates/conodonts (i.e. paraconodonts) in the upper part of Cambrian Stage 5 (Donoghue, 2002; Donoghue \& Sansom, 2002; Kemp, 2002a,b; online Appendices $1 \& 2$ at http://journals.cambridge.org/geo) and dermal biomineralization in agnathan-like chordates by the end 
of the Cambrian (Cambrian Stage 9) (Smith \& Sansom, 1995; Smith, Sansom \& Cochrane, 2001; Young, 2009) post-date both the Cambrian radiation and the first fossils interpreted as chordates by $c .10$ and $25 \mathrm{Ma}$, respectively.

The fossil record of sponges and cnidarians suggests that they acquired skeletal biomineralization in the Precambrian (online Appendices 1 \& 2 at http://journals.cambridge.org/geo; Fig. 2), but it was not until diverse bilaterian groups become abundant in the fossil record that radiation among skeletonized non-bilaterians like these occurred. Although solitary tubular forms with questionable affinities to cnidarians are already diverse during the first phase of the early Cambrian bilaterian radiation, biomineralized remains of sponges and spongiomorphs are sporadic until the Cambrian Stage 2, where corallomorphs also entered the fossil record (online Appendices 1 \& 2 at http://journals.cambridge.org/geo; Fig. 2).

Distribution of calcium carbonate skeletal mineralogies from upper Ediacaran to lower Cambrian (Fig. 2) are shown to reflect fluctuations in the magnesium/calcium ratio in the ocean (Zhuravlev, 1993; Ushatinskaya \& Zhuravlev, 1994; Porter, 2007; Zhuravlev \& Wood, 2008). First appearances of animal groups with aragonite skeletons occur mainly during the Fortunian Age. A few rare and speculative cases of low-magnesium calcite (LMC) biomineralization have been attributed to the Cambrian Stage 2, including Khasagtina primaria (kutorginid brachiopod?) and the earliest stenothecoids (Zhuravlev \& Wood, 2008; Fig. 2), but their mineralogy is only suggested from the inferred composition of younger forms, and hence alternative carbonate mineralogies cannot be excluded.

The second phase of the early Cambrian bilaterian radiation occurred after one of the major perturbances in the carbon cycle in the Phanerozoic Earth history, marked with a c. $10 \%$ negative shift in $\delta^{13} \mathrm{C}$ record in the middle of Stage 2 (online Fig. S1 at http://journals.cambridge.org/geo). The upper part of Stage 2, generally correlated herein with the Tommotian Stage of Siberia, represents a transitional interval with first appearances of high-magnesium calcite (HMC) skeletons, a transition that probably corresponds to decreasing $\mathrm{Mg} / \mathrm{Ca}$ ratio of the ocean. The second phase, marked by the first appearance of trilobites (Fig. 2), is characterized by the onset of the LMC biomineralization in trilobites and brachiopods and a short-term switch to the calcite sea in the early Atdabanian (Zhuravlev \& Wood, 2008). Based on distribution of inorganic precipitates and the relative abundance of genera with aragonite and HMC v. LMC skeletal mineralogies, the remaining part of the second phase is characterized, however, as a reappearance of the aragonite sea (Zhuravlev \& Wood, 2008). Hence, despite an increasing number of genera with LMC skeletons during the second phase, the Cambrian radiation interval was generally aragonite and HMC favourable.
Acknowledgements. Artem Kouchinsky acknowledges support from the NASA Astrobiology Institute and the Swedish Research Council (Grant No. 621-2001-1751 to Stefan Bengtson and Grant No. 623-2003-207 to Artem Kouchinsky) at the initial stage of work in 2002-2005. Artem Kouchinsky was also supported later from the NordCEE (Nordic Centre for Earth Evolution) project (Danish National Research Foundation (Danmarks Grundforskningsfond)) grant to Prof. Donald Canfield. Igor Korovnikov (Institute of Oil-and-Gas Geology and Geophysics, Novosibirsk, Russia) and John Malinky are acknowledged for useful personal communication. We also thank Andrej Zhuravlev (Universidad de Zaragoza, Spain) for invaluable information and critical revision of this work. Ed Landing and Martin Brasier provided detailed reviews of the manuscript.

\section{References}

AKSARINA, N. A. 1968. Probivalvia-novyy klass drevneyshikh mollyuskov. [Probivalvia-a new class of ancient molluscs.] In Novye dannye po geologii i poleznym iskopaemym Zapadnoy Sibiri. [New data on geology and natural resources of western Siberia.] (ed. G. A. Selyatitskiy), pp. 77-86. Tomsk: Tomsk University Press (in Russian).

Allison, C. W. \& AWramiK, S. M. 1989. Organic-walled microfossils from earliest Cambrian or latest Proterozoic Tindir Group rocks, northwest Canada. Precambrian Research 43, 253-94.

Álvaro, J. J., Ahlberg, P., BABCock, L. E., BordonAro, O. L., Choi, D. K., Cooper, R. A., Ergaliev, G. K., Gapp, I. W., Pour, M. G., Hughes, N. C., Jago, J. B., Korovnikov, I., Laurie, J. R., Lieberman, B. S., Paterson, J. R., Pegel, T. V., Popov, L. E., Rushton, A. W. A., Sukhov, S. S., Tortello, M. F., Zhou, Z. \& ŻyLińsKA, A. In press. Global Cambrian trilobite palaeobiogeography assessed using parsimony analysis of endemicity. In Early Palaeozoic Palaeography and Biogeography (eds D. Harper \& T. Servais). Geological Society of London, Special Publication.

AMTHOR, J. E., GROTZINGER, J. P., SCHRÖDER, S., BOWRING, S. A., Ramezani, J., Martin, M. W. \& Matter, A. 2003. Extinction of Cloudina and Namacalathus at the Precambrian-Cambrian boundary in Oman. Geology 31, 431-4.

Antcliffe, J. B. \& BRASIER, M. D. 2008. Charnia at 50: developmental models for Ediacaran fronds. Palaeontology 51, 11-26.

Astashkin, V. A., Pegel', T. V., Repina, L. N., Belyaeva, G. A., EsAKova, N. V., RozANOV, A. Yu., ZHuRAVLEV, A. YU., Osadchaya, D. V. \& PaKhomov, N. N. 1995. The Cambrian System of the Foldbelts of Russia and Mongolia. International Union of Geological Sciences publication no. 32, $132 \mathrm{pp}$.

AZMI, R. J. 1996. Evidence for soft tissue basal support in earliest Cambrian protoconodonts from the Lesser Himalaya: conodont function and affinity. In Contributions to the XV Indian Colloqium on Micropaleontology and Stratigraphy (eds J. Pandey, R. J. Azmi, A. Bhandari \& A. Dave), pp. 457-61. Dehra Dun.

AZMI, R. J. \& PAUL, S. K. 2004. Discovery of PrecambrianCambrian boundary protoconodonts from the Gangolihat Dolomite of Inner Kumaun Lesser Himalaya: implication on age and correlation. Current Science 86, 1653-60. 
BABCock, L. E. \& Peng, S. 2007. Cambrian chronostratigraphy: current state and future plans. Palaeogeography, Palaeoclimatology, Palaeoecology 254, 62-6.

Babcock, L. E., Peng, S. C., Geyer, G. \& Shergold, J. H. 2005. Changing perspectives on Cambrian chronostratigraphy and progress toward subdivision of the Cambrian System. Geoscience Journal 9, 101-6.

BALTHASAR, U. 2008. Mummpikia gen. nov. and the origin of calcitic-shelled brachiopods. Palaeontology 51, 263-79.

Bengtson, S. 1968. The problematic genus Mobergella from the Lower Cambrian of the Baltic area. Lethaia 1, 32551.

Bengtson, S. 1970. The Lower Cambrian fossil Tommotia. Lethaia 3, 363-92.

Bengtson, S. 1976. The structure of some Middle Cambrian conodonts, and the early evolution of conodont structure and function. Lethaia 9, 185-206.

Bengtson, S. 1977. Aspects of problematic fossils in the early Palaeozoic. Acta Universitatis Upsaliensis. Abstracts of Uppsala Dissertations from the Faculty of Science 415, 1-71.

Bengtson, S. 1983. The early history of the Conodonta. Fossils and Strata 15, 5-19.

BengtSON, S. 1985 Taxonomy of disarticulated fossils. Journal of Paleontology 59, 1350-8.

Bengtson, S. 1986. A new Mongolian species of the Lower Cambrian genus Camenella and the problem of scleritome-based taxonomy of the Tommotiida. Paläontologische Zeitschrift 60(1-2), 45-55.

Bengtson, S. 1992a. The cap-shaped Cambrian fossil Maikhanella and the relationship between coeloscleritophorans and molluscs. Lethaia 25, 401-20.

Bengtson, S. 1992b. Proterozoic and earliest Cambrian skeletal metazoans. In The Proterozoic Biosphere: A multidisciplinary study (eds J. W. Schopf \& C. Klein), pp. 397-435. Cambridge: Cambridge University Press.

Bengtson, S. 1994. The advent of animal skeletons. In Early Life on Earth. Nobel Symposium 84 (ed. S. Bengtson), pp. 412-25. New York: Columbia University Press.

BengtSON, S. 2004. Early skeletal fossils. In Neoproterozoic-Cambrian Biological Revolutions (eds J. H. Lipps \& B. M. Waggoner), pp. 67-77. The Paleontological Society Papers 10. The Paleontological Society.

BENGTSON, S. 2005. Mineralized skeletons and early animal evolution. In Evolving Form and Function: Fossils and development (ed. D. E. G. Briggs), pp. 101-24. New Haven: Yale Peabody Museum.

Bengtson, S. \& CONWAY MoRRIS, S. 1992. Early radiation of biomineralizing phyla. In Origin and Early Evolution of the Metazoa (eds J. H. Lipps \& P. W. Signor), pp. 447-81. New York: Plenum Press.

Bengtson, S., Conway Morris, S., CoOper, B. J., Jell, P. A. \& RunNegaR, B. N. 1990. Early Cambrian fossils from South Australia. Memoirs of the Association of Australasian Palaeontologists 9, 1-364.

Bengtson, S., Fedorov, A. B., Missarzhevsky, V. V., Rozanov, A. Yu., Zhegallo, E. A. \& ZhuraVleV, A. YU. 1987. Tumulduria incomperta and the case for Tommotian trilobites. Lethaia 20, 361-70.

Bengtson, S. \& HoU, X. 2001. The integument of Cambrian chancelloriids. Acta Palaeontologica Polonica 46, 1-22.

Bengtson, S., Matthews, S. C. \& Missarzhevsky, V. V. 1986. The Cambrian netlike fossil Microdictyon. In Problematic Fossil Taxa (eds A. Hoffman \& M. H. Nitecki), pp. 97-115. New York: Oxford University Press.
Bengtson, S. \& Missarzhevsky, V. V. 1981. Coeloscleritophora - a major group of enigmatic Cambrian metazoans. In Short Papers for the Second International Symposium on the Cambrian System (ed. M. E. Taylor), pp. 19-21.

Bengtson, S. \& Yue, Z. 1997. Fossilized metazoan embryos from the earliest Cambrian. Science 277, 1645-8.

Bergström, J. 1973. Classification of olenellid trilobites and some Balto-Scandian species. Norsk Geologisk Tidsskrift 53, 283-314.

BergströM, J. 2010. The earliest arthropods and other animals. In Darwin's Heritage Today. Proceedings of the Darwin 200 International Conference (ed. M. Long), pp. 29-42. Beijing: Higher Education Press.

BergStröM, J. \& HoU, X. 2001. Cambrian Onychophora or Xenusians. Zoologischer Anzeiger 240, 237-45.

BILLINGS, E. 1871. On some new species of Palaeozoic fossils. Canadian Naturalist 6, 213-223, 240.

BotTinG, J. P. \& BUTTERFIELD, N. J. 2005. Reconstructing early sponge relationships by using the Burgess Shale fossil Eiffelia globosa, Walcott. Proceedings of the National Academy of Sciences 102, 1554-9.

Bowring, S., Grotzinger, J., Condon, D., RAmezani, J., Newall, M. \& Allen, P. 2007. Geochronologic constraints of the chronostratigraphic framework of the Neoproterozoic Huqf Supergroup, Sultanate of Oman. American Journal of Science 307, 1097-145.

BrasiER, M. D. 1989a. China and the Palaeotethyan belt (India, Pakistan, Iran, Kazakhstan, and Mongolia). In The Precambrian-Cambrian Boundary (eds J. W. Cowie \& M. D. Brasier), pp. 40-74. Oxford: Clarendon Press.

BRASIER, M. D. 1989b. Towards a biostratigraphy of the earliest skeletal biotas. In The Precambrian-Cambrian Boundary (eds J. W. Cowie \& M. D. Brasier), pp. 11765. Oxford: Clarendon Press.

Brasier, M. D. 1989c. Sections in England and their correlation. In The Precambrian-Cambrian Boundary (eds J. W. Cowie \& M. D. Brasier), pp. 82-104. Oxford: Clarendon Press.

Brasier, M. D., Corfield, R. M., Derry, L. A., Rozanov, A. Yu. \& Zhuravlev, A. Yu. 1994a. Multiple $\delta^{13} \mathrm{C}$ excursions spanning the Cambrian explosion to the Botomian crisis in Siberia. Geology 22, 455-8.

Brasier, M. D., GreEN, O. \& SHIELDS, G. 1997. Ediacarian sponge spicule clusters from southwestern Mongolia and the origins of the Cambrian fauna. Geology 25, 303-6.

Brasier, M. D., Khomentovsky, V. V. \& CoRfield, R. M. 1993. Stable isotopic calibration of the earliest skeletal fossil assemblages in eastern Siberia (PrecambrianCambrian boundary). Terra Nova 5, 225-32.

Brasier, M. D., Magaritz, M., Corfield, R., Luo, H., Wu, X., OuYANG, L., JiAnG, Z., Hamdi, B., He, T. \& FRAZIER, A. G. 1990. The carbon- and oxygen-isotopic record of the Precambrian-Cambrian boundary interval in China and Iran and their correlation. Geological Magazine 127, 319-32.

Brasier, M. D., Rozanov, A. Yu., Zhuravlev, A. Yu., Corfield, R. M. \& DERRY, L. A. 1994b. A carbon isotope reference scale for the Lower Cambrian succession in Siberia: report of IGCP project 303. Geological Magazine 131, 767-83.

Brasier, M. D., Shields, G., Kuleshov, V. N. \& ZHEGALlO, E. A. 1996. Integrated chemo- and biostratigraphic calibration of early animal evolution: Neoproterozoic-early Cambrian of southwest Mongolia. Geological Magazine 133, 445-85. 
Brasier, M. D. \& Singh, P. 1987. Microfossils and Precambrian-Cambrian boundary stratigraphy at Maldeota, Lesser Himalaya. Geological Magazine 124, 323-45.

BRASIER, M. D. \& SuKHOV, S. S. 1998. The falling amplitude of carbon isotopic oscillations through the Lower to Middle Cambrian: northern Siberia data. Canadian Journal of Earth Sciences 35, 353-73.

Brooks, B.-G., Crowley, J., Bowring, S., Cervato, C. \& JIN, Y. 2006. A new U/Pb date for the basal Meishucun section and implications for the timing of the Cambrian explosion. The Palaeontological Association Annual Meeting, University of Sheffield, Programme with abstracts, p. 18.

BuDD, G. E. 1997. Stem-group arthropods from the Lower Cambrian Sirius Passet fauna of North Greenland. In Arthropod Relationships (eds R. A. Fortey \& R. H. Thomas), pp. 125-38. London: Chapman and Hall.

BUDD, G. E. 2001. Tardigrades as 'stem-group arthropods': The evidence from the Cambrian fauna. Zoologischer Anzeiger 240, 265-79.

BuDD, G. E. 2003. The Cambrian fossil record and the origin of the phyla. Integrative and Comparative Biology 43, 157-65.

BuDD, G. E. 2008. The earliest fossil record of the animals and its significance. Philosophical Transactions of the Royal Society B 363, 1425-34.

BUDD, G. E. \& JENSEN, S. 2000. A critical reappraisal of the fossil record of the bilaterian phyla. Biological Reviews $\mathbf{7 5}, 253-95$

BudD, G. E. \& JENSEN, S. 2003. The limitations of the fossil record and the dating of the origin of the Bilateria. In Telling the Evolutionary Time: Molecular Clocks and the Fossil Record (eds P. C. J. Donoghue \& M. P. Smith), pp. 166-89. London: Taylor and Francis.

BUTTERFIELD, N. J. 2003. Exceptional fossil preservation and the Cambrian Explosion. Integrative and Comparative Biology 43, 166-77.

CHEN, M.-G. 1982. [The new knowledge of the fossil assemblages from Maidiping section, Emei County, Sichuan with reference to the Sinian-Cambrian boundary]. Scientia Geologica Sinica 1982, 253-62 (in Chinese).

Chen, J.-Y., Hou, X.-G. \& Lu, H. 1989. Early Cambrian netted scale-bearing worm-like sea animal. Acta Palaeontologica Sinica 28(1), 12-27.

Chen, J.-Y. \& HuANG, D.-Y. 2002. A possible Lower Cambrian chaetognath (arrow worm). Science 298, 187.

Chen, J.-Y. \& Huang, D.-Y., Peng, Q.-Q., ChI, H.-M., WANG, X.-Q. \& FENG, M. 2003. The first tunicate from the Early Cambrian of South China. Proceedings of the National Academy of Sciences 100, 8314-18.

CHEN, J.-Y. \& ZHOU, G.-Q. 1997. Biology of the Chengjiang fauna. Bulletin of the National Museum of Natural History (Taichung, Taiwan, China) 10, 11-105.

Chen, J.-Y., ZHOU, G.-Q. \& RAMSKÖLD, L. 1995. The Cambrian lobopodian Microdictyon sinicum. Bulletin of the National Museum of Natural Science 5, 1-93.

COMPSTON, W., Zhang, Z., COOPER, J. A., MA, G. \& JENKINS, R. J. F. 2008. Further SHRIMP geochronology on the early Cambrian of South China. American Journal of Science 308, 399-420.

Condon, D., Zhu, M., Bowring, S., WANG, W., YANG, A. \& JIN, Y. 2005. U-Pb ages from the Neoproterozoic Doushantuo Formation, China. Science 308, 958.
CONWAY MORRIS, S. 1986. The community structure of the middle Cambrian phyllopod bed (Burgess Shale). Palaeontology 29, 423-67.

CONWAY MORRIS, S. 1989. South-eastern Newfoundland and adjacent areas (Avalon Zone). In The PrecambrianCambrian Boundary (eds J. W. Cowie \& M. D. Brasier), pp. 7-39. Oxford: Clarendon Press.

CONWAY MORRIS, S. 1993. Ediacaran-like fossils in Cambrian Burgess shale-type faunas of North America. Palaeontology 36, 593-635.

CONWAY MORRIS, S. 1997. The cuticular structure of the 495Myr-old type species of the fossil worm Palaeoscolex, P. piscatorum (?Priapulida). Zoological Journal of the Linnean Society 119, 69-82.

CONwAY Morris, S. 2006. Darwin's dilemma: the realities of the Cambrian "explosion". Philosophical Transactions of the Royal Society of London B 361, 106983.

CONWAY Morris, S. \& CARON, J. B. 2007. Halwaxiids and the early evolution of the Lophotrochozoans. Science 315, 1255-8.

CONWAY MORRIS, S. \& CHAPMAN, A. J. 1997. Mobergellans from the Lower Cambrian of Mongolia, Sweden, and the United States: molluscs or opercula of incertae sedis? Journal of Paleontology 71, 968-85.

CONWAY MORRIS, S. \& CHEN, M. 1990. Tommotiids from the Lower Cambrian of South China. Journal of Paleontology 64, 169-84.

CONWAY MORRIS, S. \& CHEN, M. 1991. Cambroclaves and paracarinachitids, early skeletal problematica from the Lower Cambrian of South China. Palaeontology 34, 357-97.

CONWAY Morris, S. \& ChEN, M. 1992. Carinachitids, hexangulaconulariids, and Punctatus: problematic metazoans from the early Cambrian of South China. Journal of Paleontology 66, 384-406.

Conway Morris, S., Crampton, J. S., XiaO, B. \& CHAPMAN, A. J. 1997. Lower Cambrian cambroclaves (incertae sedis) from Xinjiang, China, with comments on the morphological variability of sclerites. Palaeontology 40, 167-89.

CONWAY Morris, S., MCIlroy, D. \& Rushton, A. W. 1998. Lower Cambrian halkieriids from Oxfordshire, U.K. Geological Magazine 135, 501-8.

CONWAY MORRIS, S. \& PEeL, J. S. 1995. Articulated halkieriids from the Lower Cambrian of North Greenland and their role in early protostome evolution. Philosophical Transactions of the Royal Society of London B 347, 305-58.

Conway Morris, S. \& Peel, J. S. 2008. The earliest annelids: Lower Cambrian polychaetes from the Sirius Passet Lagerstätte, Peary Land, North Greenland. Acta Palaeontologica Polonica 53, 137-48.

Conway Morris, S. \& PeEL, J. S. 2010. New palaeoscolecidan worms from the lower Cambrian: Sirius Passet, Latham Shale and Kinzers Shale. Acta Palaeontologica Polonica 55, 141-56.

Conway Morris, S., Peel, J. S., Higgins, A. K., SOPER, N. J. \& DAVIS, N. C. 1987. A Burgess shale-like fauna from the Lower Cambrian of North Greenland. Nature 326, 181-3.

Conway Morris, S. \& Robison, R. A. 1986. Middle Cambrian Priapulids and other soft-bodied fossils from Utah and Spain. Paleontological Contributions from the University of Kansas Papers 117, 1-22.

CRIMES, T. P. 1987. Trace fossils and correlation of late Precambrian and early Cambrian strata. Geological Magazine 124, 97-119. 
DAILY, B. 1976. Novye dannye ob osnovanii kembriya v Yuzhnoy Avstralii. [New data on the base of the Cambrian in South Australia.] Izvestiya Akademii Nauk SSSR, Seriya Geologicheskaya 1976(3), 4552.

DAILY, B. 1990. Cambrian stratigraphy of Yorke Peninsula. Geological Society of Australia, Special Publication 16, 215-29.

Debrenne, F., Gangloff, R. A. \& Zhuravlev, A. Yu. 1990. Archaeocyatha from the Krol-Tal succession (Lesser Himalaya): an invalid record. Geological Magazine 127, 361-2.

Debrenne, F. M., Lafuste, J. \& Zhuravlev, A. Yu. 1990. Coralomorphes et spongiomorphes à l'aube du Cambrien. Bulletin du Muséum National d'Histoire Naturelle 12, 17-39.

Debrenne, F. M., Maidanskaya, I. D. \& ZhuraVleV, A. YU. 1999. Faunal migrations of archaeocyaths and early Cambrian plate dynamics. Bulletin de la Société Géologique de France 170, 189-94.

Debrenne, F. M. \& ReITneR, J. 2001. Sponges, cnidarians, and ctenophores. In The Ecology of the Cambrian Radiation (eds A. Yu. Zhuravlev \& R. Riding), pp. 301325. New York: Columbia University Press.

Dickson, J. A. D. 2002. Fossil echinoderms as monitor of the $\mathrm{Mg} / \mathrm{Ca}$ ratio of Phanerozoic oceans. Science 298, 1222-4.

DiCKSON, J. A. D. 2004. Echinoderm skeletal preservation: Calcite-aragonite seas and the $\mathrm{Mg} / \mathrm{Ca}$ ratio of Phanerozoic oceans. Journal of Sedimentary Research 74, 355-65.

Dillard, K. A., Pope, M. C., Coniglio, M., Hasiotis, S. T. \& LIEBERMAN, B. S. 2007. Stable isotope geochemistry of the lower Cambrian Sekwi Formation, Northwest Territories, Canada: implications for ocean chemistry and secular curve generation. Palaeogeography, Palaeoclimatology, Palaeoecology 256, 174-94.

DING, W. \& QIAN, Y. 1988. Late Sinian to Early Cambrian small shelly fossils from Yangjiaping, Shimen, Hunan. Acta Micropalaeontologica Sinica 5(1), 39-55 (in Chinese).

Doguzhaeva, L. A., Mapes, R. H. \& Mutvei, H. 2002. Chaetognath grasping spines from the Upper Mississippian of Arkansas (USA). Acta Palaeontologica Polonica 47, 421-30.

DonG, X.-P. 2004. On the evolution and histology of some Cambrian protoconodonts, paraconodonts and primitive euconodonts. Science in China, Series D, Earth Sciences 47(7), 577-84.

Dong, X.-P., Bengtson, S., Gostling, N. J., Cunningham, J. A., Walossek, D., Harvey, T. H. P., Kouchinsky, A., VAL'KOV, A. K., RePeTSKI, J. E., STAMPANONI, M. \& Donoghue, P. C. J. 2010. The anatomy, taphonomy, taxonomy and systematic affinity of Markuelia: Early Cambrian to Early Ordovician scalidophorans. Palaeontology 53, 1291-314.

Dong, X.-P., Donoghue, P. C. J., Cheng, H. \& LiU, J. 2004. Fossil embryos from the Middle and Late Cambrian Period of Hunan, south China. Nature 427, 23740.

Dong, X.-P., Donoghue, P. C. J., Cunningham, J. A., LIU, J. \& CHENG, H. 2005. The anatomy, affinity, and phylogenetic significance of Markuelia. Evolution \& Development 7, 468-82.

DonoghUE, P. C. J. 2002. Evolution of development of the vertebrate dermal and oral skeletons: unraveling concepts, regulatory theories, and homologies. Paleobiology 28, 474-507.
Donoghue, P. C. J., Forey, P. L. \& Aldridge, R. J. 2000. Conodont affinity and chordate phylogeny. Biological Reviews 75, 191-251.

Donoghue, P. C. J. \& SAnsom, I. J. 2002. Origin and early evolution of vertebrate skeletonization. Microscopy Research and Technique 59, 352-72.

Donoghue, P. C. J., SAnsom, I. J. \& Downs, J. P. 2006. Early evolution of vertebrate skeletal tissues and cellular interactions, and the canalization of skeletal development. Journal of Experimental Zoology, Part B: Molecular and Developmental Evolution 306B, 278-94.

Dunn, C. W., Hejnol, A., Matus, D. Q., Pang, K., Browne, W. E., Smith, S. A., Seaver, E., Rouse, G. W., Obst, M., Edgecombe, G. D., Sørensen, M. V., Haddock, S. H. D., Schmidt-Rhaesa, A., OKusu, A., Kristensen, R. M., Wheeler, W. C., Martindale, M. Q. \& GIRIBET, G. 2008. Broad phylogenomic sampling improves resolution of the animal tree of life. Nature 452, 745-9.

Durham, J. W. 1971. The fossil record and the origin of the Deuterostomata. Proceedings of the North American Paleontological Convention, Part H, 1104-32.

Dutro, J. T. JR., PAlmer, A. R., RePetski, J. E. \& Brosgé, W. P. 1984. Middle Cambrian fossils from the Doonerak Anticlinorium, Central Brooks Range, Alaska. Journal of Paleontology 58, 1364-71.

DZIK, J. 1994. Evolution of "small shelly fossils" assemblages of the Early Paleozoic. Acta Palaeontologica Polonica 39, 247-313.

DZIK, J. 2010. Brachiopod identity of the alleged monoplacophoran ancestors of cephalopods. Malacologia 52, 97 113.

EdGeCOMBE, G. D. 2009. Palaeontological and molecular evidence linking Arthropods, Onychophorans, and other Ecdysozoa. Evolution: Education and Outreach 2, 17890.

ELICKI, O. 1994. Lower Cambrian carbonates from eastern Germany: palaeontology, stratigraphy and palaeogeography. Neues Jahrbuch für Geologie und Paläontologie, Abhandlungen 191/1, 69-93.

Elicki, O. \& WotTe, T. 2003. Cambroclaves from the Cambrian of Sardinia (Italy) and Germany: constraints for the architecture of western Gondwana and the palaeogeographical and palaeoecological potential of cambroclaves. Palaeogeography, Palaeoclimatology, Palaeoecology 195, 55-71.

EsaKoVA, N. V. \& ZHEGALlo, E. A. 1996. Biostratigrafiya i fauna nizhnego kembriya Mongolii. [Biostratigraphy and fauna of the Lower Cambrian of Mongolia.] In Transactions of the Joint Russian-Mongolian Paleontological Expedition 46 (ed. A. Yu. Rozanov), 216 pp. (in Russian).

FATKA, O., KRAFT, P. \& SZABAD, M. 2011. Shallow-water occurrence of Wiwaxia in the middle Cambrian of the Barrandian area (Czech Republic). Acta Palaeontologica Polonica doi:10.4202/app.2009.0052.

Fedonkin, M. A. \& Waggoner, B. M. 1997. The Vendian fossil Kimberella: The oldest mollusk. Nature 388, 86871.

Fedorov, A. B. 1986. Novye trubchatye problematiki iz stratotipa tommotskogo yarusa. [New tubular problematics from stratotype of the Tommotian Stage]. Paleontologicheskij Zhurnal 1986(3), 110-2. (English translation: Paleontological Journal 20(3), 103-5.)

Fedorov, A. B. \& Shishkin, B. B. 1984. Nizhnyaya granitsa kembriya na severe Sibirskoj platformy. [Lower boundary of the Cambrian in north of the Siberian Platform.] In Problemy yarusnogo raschleneniya sistem 
fanerozoya Sibiri. [Problems of Stage subdivision of Phanerozoic Systems of Siberia] (ed. V. I. Krasnov), pp. 5-14. Novosibirsk: SNIIGGiMS (in Russian).

FISHER, D. W. 1962. Other small conoidal shells. In Treatise on Invertebrate Paleontology. Miscellanea (ed. R. C. Moore), W98-W143. Lawrence: Geological Society of America and University of Kansas Press.

FLÜGEL, E. \& SINGH, I. B. 2003. Stromatoporoid-grade and other sponge fossils from the upper Krol Formation of the Lesser Himalaya (India): implications for the biotic evolution around the Precambrian-Cambrian boundary interval. Facies 49, 351-72.

GeHLing, J. \& RigBY, J. K. 1996. Long expected sponges from the Neoproterozoic Ediacara fauna of South Australia. Journal of Paleontology 70, 185-95.

GERMS, G. L. 1972. New shelly fossils from the Nama Group, South West Africa. American Journal of Science 272, 752-61.

GEYER, G. \& ELICKI, O. 1995. The Lower Cambrian trilobites from the Görlitz Synclinorium (Germany) - review and new results. Paläontologische Zeitschrift 69(1/2), 87119.

GeYeR, G. \& LANDING, E. 2004. A unified Lower-Middle Cambrian chronostratigraphy for West Gondwana. Acta Geologica Polonica 54, 179-218.

GOLUBEV, S. N. 1976. Ontogenetic changes and evolutionary trends in Early Cambrian spiral gastropods of the superfamily Pelagiellacea. Paleontological Journal 10(2), $143-9$.

GORYANSKY, V. Y. 1977. Pervaya nakhodka ostatkov gubki v nizhnem kembrii vostochnoj Sibiri. [The first find of sponge remains in the Lower Cambrian of eastern Siberia]. Ezhegodnik Vsesoyuznogo Paleontologicheskogo Obschestva 20, 274-6.

GRANT, S. W. F. 1990. Shell structure and distribution of Cloudina, a potential index fossil for the terminal Proterozoic. American Journal of Science 290(A), 26194.

GraVestock, D. I. \& Shergold, J. H. 2001. Australian Early and Middle Cambrian sequence biostratigraphy with implications for species diversity and correlation. In The Ecology of the Cambrian Radiation (eds A. Yu. Zhuravlev \& R. Riding), pp. 105-136. New York: Columbia University Press.

Gravestock, D. I., Alexander, E. M., Demidenko, Yu. E., Esakova, N. V., Holmer, L. E., Jago, J. B., Lin, T., Melnikova, L. M., Parkhaev, P. YU., Rozanov, A. Yu., Ushatinskaya, G. T., ZANG, W., Zhegallo, E. A. \& Zhuravlev, A. YU. 2001. The Cambrian biostratigraphy of the Stansbury Basin, South Australia. Transactions of the Palaeontological Institute 282. Moscow: IAPC Nauka/Interperiodica, $344 \mathrm{pp}$.

Grigor'eva, N. V., Melnikova, L. M. \& Pel'Man, Yu. L. 1983. Brakhiopody, ostrakody (bradoriidy) i problematika iz stratotipicheskogo rajona yarusov nizhnego kembriya. [Brachiopods, ostracods (bradoriids) and problematics from the stratotype region of Lower Cambrian Stages]. Paleontologicheskij Zhurnal 1983(3), 548. (English translation: Paleontological Journal 17(3), 51-6).

Grotzinger, J. P., AdAMS, E. \& Schröder, S. 2005. Microbial-metazoan reefs of the terminal Proterozoic Nama Group (ca. 550-543 Ma), Namibia. Geological Magazine 142, 499-517.

Grotzinger, J. P., Bowring, S. A., SAYlor, B. Z. \& KAUFMAN, A. J. 1995. Biostratigraphic and geochronologic constraints on early animal evolution. Science $\mathbf{2 7 0}$, 598-604.
Grotzinger, J. P., Watters, W. A. \& Knoll, A. H. 2000. Calcified metazoans in thrombolite-stromatolite reefs of the terminal Proterozoic Nama Group, Namibia. Paleobiology 26, 334-59.

HALANYCH, K. M. 2004. The new view of animal phylogeny. Annual Review of Ecology, Evolution and Systematics 35, 229-56.

HALl, J. 1847. Paleontology of New-York. Volume I. Containing descriptions of the organic remains of the Lower Division of the New-York system (equivalent to the Lower Silurian rocks of Europe). Albany: C. Van Benthuysen, $338 \mathrm{pp}$.

HALl, J. 1876. Illustrations of Devonian Fossils: Gasteropoda, Pteropoda, Cephalopoda, Crustacea and Corals of the Upper Helderberg, Hamilton and Chemung Groups. 39 pls. Albany: Weed, Parsons and Company.

HAMDI, B. 1995. Precambrian-Cambrian deposits in Iran. In Treatise on the Geology of Iran vol. 20 (ed. A. Hushmandzadeh). Tehran: Geological Survey of Iran, 535 pp. (In Persian)

HAMDI, B., BRASIER, M. D. \& JiANG, Z. 1989. Earliest skeletal fossils from Precambrian-Cambrian boundary strata, Elburz Mountains, Iran. Geological Magazine 126, 283-9.

Hardie, L. A. \& Stanley, S. M. 1997. Secular biotic trends in skeletal secretion and sedimentary carbonate production resulting from oscillations in seawater chemistry driven by plate tectonics. Eos (Transactions of the American Geophysical Union) 78, S179.

HARVEY, T. H. P. 2010. Carbonaceous preservation of Cambrian hexactinellid sponge spicules. Biology Letters 6, 834-7.

HarveY, T. H. P., Dong, X. \& Donoghue, P. C. J. 2010. Are palaeoscolecids ancestral ecdysozoans? Evolution \& Development 12, 177-200.

HINZ, I. 1987. The Lower Cambrian microfauna of Comley and Rushton, Shropshire/England. Palaeontographica A, 198(1-3), 41-100.

HinZ-Schallreuter, I., Gozalo, R. \& LiÑÁN, E. 2008. New bradorid arthropods from the Lower Cambrian of Spain. Micropalaeontology 53, 497-510.

HOLLINGSWORTH, J. S. 2005. The earliest occurrence of trilobites and brachiopods in the Cambrian of Laurentia. Palaeogeography, Palaeoclimatology, Palaeoecology 220, 153-65.

HOllingSWORTH, J. S. 2007. Fallotaspidoid trilobite assemblage (Lower Cambrian) from the Esmeralda Basin (western Nevada, U.S.A.): the oldest trilobites from Laurentia. Memoirs of the Australasian Association of Palaeontologists 32, 123-40.

HOLlingSWORTH, J. S. 2008. The first trilobites in Laurentia and elsewhere. In Advances in Trilobite Research (eds I. Rábano, R. Gozalo \& D. García-Bellido), pp. 1717. Cuadernos del Museo Geominero no. 9. Madrid: Instituto Geológico y Minero de España.

Holm, G. 1893. Sveriges Kambrisk-Siluriska Hyolithidae och Conularidae. Sveriges Geologiska Undersökning. Afhandlingar och Uppsatser 112, 1-172.

Holmer, L. E., Popov, L. E., Koneva, S. P. \& BAssett, M. G. 2001. Cambrian-early Ordovician brachiopods from Malyi Karatau, the western Balkhash region, and Tien Shan, central Asia. Special Papers in Palaeontology 65, $1-180$.

Holmer, L. E., Skovsted, C. B., Brock, G. A., VAlentine, J. \& PATERson, J. R. 2008. The origin of linguliform brachiopods from sessile Early Cambrian tannuolinids. Biology Letters 4, 724-8. 
Hou, X.-G. \& Bergström, J. 1994. Palaeoscolecid worms may be nematomorphs rather than annelids. Lethaia $\mathbf{2 7}$ $11-7$.

HoU, X.-G. \& Bergström, J. 1995. Cambrian lobopodiansancestors of extant onychophorans? Zoological Journal of the Linnean Society 114, 3-19.

Hou, X.-G., MA, X.-Y., ZhaO, J. \& Bergström, J. 2004. The lobopodian Paucipodia inermis from the Lower Cambrian Chengjiang fauna, Yunnan, China. Lethaia 37, 235-44.

Hou, X.-G., Siveter, D. J., Williams, M. \& Feng, X. H. 2002. A monograph of the bradoriid arthropods from the Lower Cambrian of SW China. Transactions of the Royal Society of Edinburgh: Earth Sciences 92, 347-409 (reprinted in 93, Part 1, with improved illustrations).

Hou, X.-G., Siveter, D. J., Williams, M., Walossek, D. \& BergströM, J. 1996. Appendages of the arthropod Kunmingella from the Early Cambrian of China: its bearing on the systematic position of the Bradoriida and the fossil record of the Ostracoda. Philosophical Transactions of the Royal Society of London B 351, 1131-45.

Hou, X.-G., Williams, M., Siveter, D. J., Siveter, D. J., Aldridge, R. J. \& SANSOM, R. S. 2010. Soft-part anatomy of the Early Cambrian bivalved arthropods Kunyangella and Kunmingella: significance for the phylogenetic relationships of Bradoriida. Proceedings of the Royal Society B 277, 1835-41.

HU, S. 2005. Taphonomy and palaeoecology of the Early Cambrian Chengjiang Biota from Eastern Yunnan, China. Berliner Paläobiologische Abhandlungen 7, 1197.

Hughes, N. C., Peng, S., Bhargava, O. N., Ahluwalia, A. D., Walia, S., Myrow, P. M. \& Parcha, S. K. 2005. Cambrian biostratigraphy of the Tal Group, Lesser Himalaya, India, and early Tsanglangpuan (late early Cambrian) trilobites from the Nigali Dhar syncline. Geological Magazine 142, 57-80.

IsACHSEN, C. E., BOWring, S. A., LANDING, E. \& SAMSON, S. D. 1994. New constraint on the division of Cambrian time. Geology 22, 496-8.

IVANTSOV, A. YU. 1990. Pervye nakhodki fillokarid v nizhnem kembrii Yakutii. [First finds of phyllocarids in the Lower Cambrian of Yakutia]. Paleontologicheskij Zhurnal 1990, 130-132.

Ivantsov, A. Yu., Malahovskaya, Ya. E. \& SERezhNIKOVA, E. A. 2004. Some problematic fossils from the Vendian of Southeastern White Sea Region. Paleontological Journal 38, 1-9 (translated from Paleontologicheskij Zhurnal 2004(1), 3-9).

Ivantsov, A. Yu., Zhuravlev, A. Yu., Leguta, A. V., Krasilov, V. A., MELniKova, L. M. \& UshatinsKayA, G. T. 2005. Palaeoecology of the Early Cambrian Sinsk biota from the Siberian Platform. Palaeogeography, Palaeoclimatology, Palaeoecology 220, 69-88.

JAeKel, O. 1918. Phylogenie und System der Pelmatozoen. Paläontologische Zeitschrift 3, 1-128.

JAGO, J. B., Sun, X. \& ZANG, W. 2002. Correlation within early Palaeozoic basins of eastern South Australia. South Australia. Department of Primary Industries and Resources. Report Book 2002/033, 22 pp.

JAGO, J. B., ZANG, W., Sun, X., Brock, G. A., PATERson, J. R. \& Skovsted, C. B. 2006. A review of the Cambrian biostratigraphy of South Australia. Palaeoworld 15, 406-23.

Janussen, D., Steiner, M. \& ZhU, M.-Y. 2002. New well-preserved scleritomes of Chancelloriidae from the
Early Cambrian of Yuanshan Formation (Chengjiang, China) and the Middle Cambrian Wheeler Shale (Utah, USA) and paleobiological implications. Journal of Paleontology 76, 596-606.

JENSEN, S., GeHLING, J. \& Droser, M. 1998. Ediacara-type fossils in Cambrian sediments. Nature 393, 567-9.

JIANG, Z. 1980. [The Meishucun Stage and fauna of the Jinning County, Yunnan.] Bulletin of the Chinese Academy of Geological Sciences, Series I 2:1, 75-92. (In Chinese with an English summary)

Johnston, P. A., Johnston, K. J., Collom, C. J., Powell, W. G. \& Pollock, R. J. 2009. Palaeontology and depositional environments of ancient brine seeps in the Middle Cambrian Burgess Shale at The Monarch, British Columbia, Canada. Palaeogeography, Palaeoclimatology, Palaeoecology 277, 86-105.

Jones, P. J. \& McKenzIE, K. G. 1980. Queensland Middle Cambrian Bradoriida (Crustacea): new taxa, palaeobiogeography and biological affinities. Alcheringa 4, 203 25.

Karatajute-TalimaA, V. 1997. Taxonomy of loganiid thelodonts. Modern Geology 21(1/2), 1-15.

Karlova, G. A. 1987. First findings of skeletal fauna in the Turkut Formation of the Olenyok uplift. Doklady Akademii Nauk SSSR 292, 204-5.

Karlova, G. A. \& VodanyUK, S. A. 1985. Novye dannye o perekhodnykh k kembriyu otlozheniyakh bassejna r. Khorbosuonki (Olenyokskoe podnyatie). [New data on the deposits transitional to the Cambrian from the Khorbosuonka River basin (Olenyok Uplift)]. In Stratigrafiya pozdnego dokembriya i rannego paleozoya Sibiri. Vend i rifej. [ Stratigraphy of the late Precambrian and early Paleozoic of Siberia. Vendian and Riphean.] (ed. V. V. Khomentovsky), pp. 3-13. Novosibirsk: Institut geologii i geofiziki SO AN SSSR (in Russian).

Kaufman, A. J., KnOll, A. H. \& Awramik, S. M. 1992. Biostratigraphic and chemostratigraphic correlation of Neoproterozoic sedimentary successions: Upper Tindir Group, northwestern Canada, as a test case. Geology 20, $181-5$.

Kaufman, A. J., Knoll, A. H., Semikhatov, M. A., Grotzinger, J. P., Jacobsen, S. B. \& AdAMs, W. 1996. Integrated chronostratigraphy of Proterozoic-Cambrian boundary beds in the western Anabar region, northern Siberia. Geological Magazine 133, 509-33.

KEMP, A. $2002 a$. Amino acid residues in conodont elements. Journal of Paleontology 76, 518-28.

KEMP, A. 2002b. Hyaline tissue of thermally unaltered conodont elements and the enamel of vertebrates. Alcheringa 26, 23-36.

Kheraskova, T. N., DidenKo, A. N., Bush, V. A. \& Volozh, YU. A. 2003. The Vendian-early Paleozoic history of the continental margin of eastern Paleogondwana, Paleoasian ocean, and Central Asian foldbelt. Russian Journal of Earth Sciences 5, 165-84.

Khomentovsky, V. V. \& GiBsher, A. S. 1996. The Neoproterozoic-lower Cambrian in northern GoviAltay, western Mongolia: regional setting, lithostratigraphy and biostratigraphy. Geological Magazine 133, $371-90$.

Khomentovsky, V. V. \& Karlova, G. A. 1991. Novye dannye po korrelyatsii vend-kembrijskikh otlozhenij vostochnoj i perekhodnoj fatsial'nykh oblastej yuzhnoj Yakutii. [New data on correlation of the VendianCambrian deposits of eastern and transitional facial belts of southern Yakutia.] In Pozdnij dokembrij i rannij paleozoj Sibiri. Sibirskaya platforma $i$ ee obramlenie. [Late Precambrian and early Palaeozoic of 
Siberia. Siberian Platform and its margins.] (ed. V. V. Khomentovsky), pp. 3-44. Novosibirsk: OIGGM SO AN SSSR Publishing House (in Russian).

Khomentovsky, V. V. \& Karlova, G. A. 1993. Biostratigraphy of the Vendian-Cambrian beds and lower Cambrian boundary in Siberia. Geological Magazine 130, 29-45.

Khomentovsky, V. V. \& Karlova, G. A. 2002. Granitsa nemakit-daldynskogo i tommotskoga yarusov (vendkembrij) Sibiri. [The boundary between NemakitDaldynian and Tommotian stages (Vendian-Cambrian) of Siberia.] Stratigraphy and Geological Correlation 10, $13-34$.

Khomentovsky, V. V. \& Karlova, G. A. 2005. The Tommotian Stage base as the Cambrian lower boundary in Siberia. Stratigraphy and Geological Correlation 13, 21-34.

Khomentovsky, V. V. \& RePinA, L. N. 1965. The Lower Cambrian Stratotype Section of Siberia. Moscow: Nauka, 200 pp.

Khomentovsky, V. V., VAL'KOV, A. K. \& KARLOVA, G. A. 1990. Novye dannye po biostratigrafii perekhodnykh vend-kembrijskikh sloev v bassejne srednego techeniya $\mathrm{r}$. Aldan. [New data on the biostratigraphy of transitional Vendian-Cambrian strata in the middle reaches of the River Aldan.] In Pozdnij dokembrij $i$ rannij paleozoj Sibiri. Voprosy regional'noj stratigrafii. [Late Precambrian and early Palaeozoic of Siberia. Problems in regional stratigraphy.] (eds V. V. Khomentovsky \& A. S. Gibsher), pp. 3-57. Novosibirsk: Institut geologii i geofiziki SO AN SSSR (in Russian).

Khomentovsky, V. V., VAL'KOV, A. K., KarlovA, G. A. \& NuZHNOV, S. V. 1983. Opornyj razrez dokembrijskokembrijskikh otlozhenij r. Gonam. [Key-section of the Precambrian-Cambrian deposits of River Gonam]. In Pozdnij dokembrij i rannij paleozoj Sibiri. Vendskie otlozheniya. [Late Precambrian and early Palaeozoic of Siberia. Vendian deposits.] (eds V. V. Khomentovsky, M. S. Yakshin \& G. A. Karlova), pp. 29-44. Novosibirsk: Institut geologii i geofiziki SO AN SSSR (in Russian)

KIEL, S. \& DANDO, P. R. 2009. Chaetopterid tubes from vent and seep sites: implications for fossil record and evolutionary history of vent and seep annelids. Acta Palaeontologica Polonica 54, 443-8.

Kiessling, W., Aberhan, M. \& Villier, L. 2008. Phanerozoic trends in skeletal mineralogy driven by mass extinctions. Nature Geoscience 1, 527-30.

Kimura, H. \& Watanabe, Y. 2001. Oceanic anoxia at the Precambrian-Cambrian boundary. Geology 29, 995-8.

Kimura, H., Matsumoto, R., KaKUWA, Y., Hamdi, B. \& ZiBASERESHT, H. 1997. The Vendian-Cambrian $\delta^{13} \mathrm{C}$ record, North Iran: evidence for overturning of the ocean before the Cambrian explosion. Earth and Planetary Science Letters 147, E1-E7.

KirschVinK, J. L., MAGaritz, M., RipPerdan, R. L., Zhuravlev, A. Yu. \& Rozanov, A. Yu. 1991. The Precambrian-Cambrian boundary: magnetostratigraphy and carbon isotopes resolve correlation problems between Siberia, Morocco, and South China. GSA Today 1, 69-71, 87, 91 .

Knoll, A. H., Grotzinger, J. P., Kaufman, A. J. \& Kolosov, P. 1995. Integrated approaches to terminal Proterozoic stratigraphy: an example from the Olenek Uplift, northeastern Siberia. Precambrian Research 73, 251-70.

Korshunov, V. I., Repina, L. N. \& Sysoev, V. A. 1969. $\mathrm{K}$ stroeniyu pestrotsvetnoj svity vostoka Aldanskoj anteklizy. [To the structure of the Pestrotsvet Formaton of eastern Aldan anticline.] Geologiya i Geofizika 10, $18-21$.

KOUCHINSKY, A. 2000. Skeletal microstructures of hyoliths from the Early Cambrian of Siberia. Alcheringa 24, 6581.

Kouchinsky, A., Bengtson, S., Feng, W., Kutygin, R. \& VAL'KOV, A. K. 2009. The Lower Cambrian fossil Anabaritids: affinities, occurrences and systematics. Journal of Systematic Palaeontology 7, 241-98.

Kouchinsky, A., Bengtson, S., Missarzhevsky, V. V., Pelechaty, S., TORSSANDER, P. \& VAL'KOV, A. K. 2001. Carbon isotope stratigraphy and the problem of a pre-Tommotian Stage in Siberia. Geological Magazine 138, 387-96.

Kouchinsky, A., Bengtson, S., PaVlov, V., Runnegar, B., VAL'KOV, A. K. \& YounG, E. 2005. Pre-Tommotian age of the lower Pestrotsvet Formation in the Selinde section on the Siberian platform: carbon isotopic evidence. Geological Magazine 142, 319-25.

Kouchinsky, A., Bengtson, S., PAVlov, V. E., Runnegar, B., TORssander, P., Young, E. \& ZIEgler, K. 2007. Carbon isotope stratigraphy of the PrecambrianCambrian Sukharikha River section, northwestern Siberian platform. Geological Magazine 144, 1-10.

Kruse, P. D., Zhuravlev, A. Yu. \& James, N. P. 1995. Primordial metazoan-calcimicrobial reefs: Tommotian (Early Cambrian) of the Siberian Platform. Palaios 10, 291-321.

LANDING, E. 1980. Late Cambrian-Early Ordovician macrofaunas and phosphatic microfaunas, St. John Group, New Brunswick. Journal of Paleontology 54, 75261.

LANDING, E. 1984. Skeleton of lapworthellids and the suprageneric classification of tommotiids (Early and Middle Cambrian phosphatic problematica). Journal of Paleontology 58, 1380-98.

LANDING, E. 1995. Upper Placentian-Branchian Series of Mainland Nova Scotia (Middle-Upper Lower Cambrian): faunas, paleoenvironments, and stratigraphic revision. Journal of Paleontology 69, 475-95.

LANDING, E. 2004. Precambrian-Cambrian boundary interval deposition and the marginal platform of the Avalon microcontinent. Journal of Geodynamics 37, 411-35.

Landing, E., Bowring, S. A., DavideK, K. L., Westrop, S. R., Geyer, G. \& Heldmaier, W. 1998. Duration of the Early Cambrian: U-Pb ages of volcanic ashes from Avalon and Gondwana. Canadian Journal of Earth Sciences 35, 329-38.

LANDing, E., ENGLish, A. \& KePpIE, J. D. 2010. Cambrian origin of all skeletalized metazoan phyla-discovery of Earth's oldest bryozoans (Upper Cambrian, southern Mexico). Geology 38, 547-50.

Landing, E., Myrow, P. M., Benus, A. \& Narbonne, G. M. 1989. The Placentian Series: appearance of the oldest skeletalized faunas in southeastern Newfoundland. Journal of Paleontology 63, 739-69.

LANDING, E., Nowlan, G. S. \& Fletcher, T. P. 1980. A microfauna associated with Early Cambrian faunas of the Callavia Zone, northern Antigonish Highlands, Nova Scotia. Canadian Journal of Earth Sciences 17, 400-18.

Landing, E., Peng, S., Babcock, L. E., Geyer, G. \& MocZYDLOWSKA-VIDAL, M. 2007. Global Standard names for the lowermost Cambrian series and stage. Episodes 30, 287-9.

LANDING, E. \& WeStrop, S. R. 1998. Revisions in stratigraphic nomenclature of the Cambrian of Avalonian 
North America and comparisons with Avalonian Britain. In Avalon 1997 - The Cambrian Standard. Third International Field Conference of the Cambrian Chronostratigraphy Working Group and I.G.C.P. Project 366 (Ecological Aspects of the Cambrian Radiation) (eds E. Landing E. \& S. R. Westrop), pp. 76-87. New York State Museum Bulletin 492.

LANDing, E. \& Westrop, S. R. 2004. Environmental patterns in the origin and evolution and diversification loci of Early Cambrian skeletalized Metazoa: evidence from the Avalon microcontinent. In NeoproterozoicCambrian Biological Revolutions (eds J. H. Lipps \& B. M. Waggoner), pp. 93-105. Paleontological Society Papers 10. The Paleontological Society.

LAURIE, J. R. 1986. Phosphatic fauna of the Early Cambrian Todd River Dolomite, Amadeus Basin, central Australia. Alcheringa 10, 431-54.

LENDZION, K. 1972. Stratigrafia kambru dolnego na obszarze Podlasia. Institut Geologiczny, Biuletyn 233. Z badan stratigraficzno-paleontologicznych w Polsce, t. VI, 69157.

LENDZION, K. 1978. Charakterystyka stratygraficznolitologiczna wendu i kambru dolnego. In Wybrane problemy stratigrafii i litologii wendu $i$ dolnego kambru na platformie prekambryjskiej $w$ Polsce. Prace Instytutu Geologicznego 90, 36-41.

LENDZION, K. 1983. Trilobita. In Upper Precambrian and Cambrian Paleontology of East-European Platform (eds N. A. Volkova, M. B. Gnilovskaya, K. Lendzion, V. V. Kirjanov, V. M. Palij, L. T. Pashkyavichene, L. V. Piskun, E. Posti, A. Yu. Rozanov, A. Urbanek, M. A. Fedonkin \& T. V. Yankauskas), pp. 95-102. Moscow: Nauka.

LI, G. 2009. Early Cambrian stem-group brachiopods from South China. In An International Conference on the Cambrian Explosion - Banff, Alberta, August 3-8, 2009, Abstract Volume (eds M. Smith, L. O'Brien \& J.-B. Caron). Toronto: Burgess Shale Consortium (available online at: http://burgess-shale.info/abstract/li).

LI, G. \& CHEN, J. 1992. [Early Cambrian cap-shaped lathamellids: their microstructures and systematics]. Acta Palaeontologica Sinica 31, 467-80. (in Chinese)

LI, C.-W., Chen, J.-Y. \& HuA, T.-E. 1998. Precambrian sponges with cellular structures. Science 279, 87982.

LI, D., Ling, H.-F., Jiang, S.-Y., Pan, J.-Y., Chen, Y.-Q., CAI, Y.-F. \& FENG, H.-Z. 2009. New carbon isotope stratigraphy of the Ediacaran-Cambrian boundary interval from SW China: implications for global correlation. Geological Magazine 146, 465-84.

Li, G., Steiner, M., Zhu, M., ZhU, X. \& Erdtmann, B.-D. 2007. Early Cambrian fossil record of metazoans in South China: generic diversity and radiation patterns. Palaeogeography, Palaeoclimatology, Palaeoecology 254, 226-46.

LI, G. \& XIAO, S. 2004. Tannuolina and Micrina (Tannuolinidae) from the Lower Cambrian of eastern Yunnan, South China, and their scleritome reconstruction. Journal of Paleontology 78, 900-13.

LI, G., ZHANG, J.-M. \& ZHU, M. 2001. Litho- and biostratigraphy of the Lower Cambrian Meishucunian Stage in the Xiaotan section, Eastern Yunnan. Acta Palaeontologica Sinica 40(Supplement), 40-53.

LIEBERMAN, B. S. 2002. Phylogenetic analysis of some basal Early Cambrian trilobites, the biogeographic origins of the Eutrilobita, and the timing of the Cambrian radiation. Journal of Paleontology 76, 692-708.

Lindsay, J. F., Brasier, M. D., DornjamjaA, D., Kruse, P., Goldring, R. \& WoOd, R. A. 1996. Facies and sequence controls on the appearance of the
Cambrian biota in southwestern Mongolia: implications for the Precambrian-Cambrian boundary. Geological Magazine 133, 417-28.

LiU, J., Shu, D., Han, H., Zhang, Z. \& Zhang, X. 2007. Origin, diversification, and relationships of Cambrian lobopods. Gondwana Research 14(1-2), 277-83.

Love, G. D., Fike, D. A., Grosjean, E., Stalvies, C., Grotzinger, J., Bradley, A. S., Bowring, S., Condon, D. \& Summons, R. E. 2006. Constraining the timing of basal metazoan radiation using molecular biomarkers and $\mathrm{U}-\mathrm{Pb}$ isotope dating. Goldschmidt Conference Abstracts 2006, A371.

Love, G. D., Grosjean, E., Stalvies, C., Fike, D. A., Grotzinger, J., Bradley, A. S., Kelly, A. E., Bhatia, M., Meredith, W., Snape, C. E., Bowring, S., Condon, D. \& Summons, R. E. 2009. Fossil steroids record the appearance of Demospongiae during the Cryogenian Period. Nature 457, 718-22.

Luchinina, V. A., Korovnikov, I. V., Sipin, D. P. \& FedoseEV, A. V. 1997. Upper Vendian-Lower Cambrian biostratigraphy of the Sukharikha River section (Siberian Platform). Russian Geology and Geophysics 38(8), 1385-97.

LuO, H., JiAng, Z., Wu, X., Song, X., OuYAng, L. 1982. The Sinian-Cambrian Boundary in Eastern Yunnan, China. Kunming: Yunnan People's Publishing House, 265 pp. (in Chinese, with an English summary).

MAAS, A. \& WAlOSZEK, D. 2005. Phosphatocopina ostracode-like sister group of Eucrustacea. Hydrobiologia 538, 139-52.

Maloof, A. C., Porter, S. M., Moore, J. L., DudÁs, F. Ö., Bowring, S. A., Higgins, J. A., Fike, D. A. \& EDDY, M. P. 2010a. The earliest Cambrian record of animals and ocean geochemical change. Geological Society of America Bulletin 122, 1731-74.

Maloof, A. C., Ramezani, J., Bowring, S. A., Fike, D. A., Porter, S. M. \& MAZOUAD, M. 2010b. Constraints on early Cambrian carbon cycling from the duration of the Nemakit-Daldynian-Tommotian boundary $\delta^{13} \mathrm{C}$ shift, Morocco. Geology 38, 623-6.

Maloof, A. C., Rose, C. V., Beach, R., SAmuels, B. M., Calmet, C. C., ERwin, D. H., PoIRIER, G. R., YaO, N. \& SimOnS, F. J. 2010c. Possible animal-body fossils in pre-Marinoan limestones from South Australia. Nature Geoscience 3, 653-9.

Maloof, A. C., Schrag, D. P., Crowley, J. L. \& Bowring, S. A. 2005. An expanded record of Early Cambrian carbon cycling from the Anti-Atlas Margin, Morocco. Canadian Journal of Earth Sciences 42, 2195 216.

Mambetov, A. M. 1993. Drevnejshie skeletnye ostatki i zonal'naya stratigrafiya verkhnego dokembriya kembriya Severnogo Tyan-Shanya. [The earliest skeletonized fossils and zonal stratigraphy of the upper Precambrian-Lower Cambrian of North Tien Shan]. In Novye dannye po biostratigrafi dokembriya i paleozoya Kyrgyzstana. [New data on biostratigraphy of the Precambrian and Palaeozoic of Kyrgyzstan.] (ed. A. M. Mambetov), pp. 15-23. Bishkek: Ilim (in Russian).

Mambetov, A. M. \& RePINA, L. N. 1979. Nizhnij kembrii talasskogo Ala-Too i ego korrelyatsiya s razrezami Malogo Karatau i Sibirskoj platformy. [Lower Cambrian of the Talass Ala-Too and its correlation with sections of the Lesser Karatau and Siberian Platform.] In Biostratigrafiya $i$ paleontologiya nizhnego kembriya Sibiri. [Biostratigraphy and palaeontology of the Lower Cambrian of Siberia.] (ed. I. T. Zhuravleva), pp. 98-138. Trudy Instituta geologii i geofiziki SO AN SSSR 406. Novosibirsk: Nauka. 
Matthew, G. F. 1899. Studies on Cambrian faunas, no. 3: Upper Cambrian fauna of Mt. Stephen, British Columbia. Transactions of the Royal Society of Canada, Series 2, 5, 39-66.

Martí Mus, M., Palacios, T. \& Jensen, S. 2008. Size of the earliest mollusks: did small helcionellids grow to become large adults? Geology 36, 175-8.

MAZUMDAR, A. \& BANERJEE, D. M. 1998. Siliceous sponge spicules in the Early Cambrian Chert-phosphate Member of the Lower Tal Formation, Krol belt, Lesser Himalaya. Geology 26, 899-902.

McCaffrey, M. A., Moldowan, J. M., LiPton, P. A., Summons, R. E., Peters, K. E., Jeganathan, A. \& WATT, D. S. 1994. Paleoenvironmental implications of novel C30 steranes in Precambrian to Cenozoic age petroleum and bitumen. Geochimica et Cosmochimica Acta 58, 529-32.

MCIlROY, D. \& SzaniawsKi, H. 2000. A lower Cambrian protoconodont apparatus from the Placentian of southeastern Newfoundland. Lethaia 33, 95-102.

MeHL, D. 1998. Porifera and Chancelloriidae from the Middle Cambrian of the Georgina basin, Australia. Palaeontology 41, 1153-82.

MENS, K. \& PIRRUS, E. A. 1977. Stratotypicheskie razrezy kembriya Estonii. [Stratotype sections of the Cambrian of Estonia]. Tallinn: Valgus, 68 pp. (in Russian)

Meshiova, N. P., Nikolaeva, I. V., Kulikov, P. Yu., ZhuraVleVA, I. T., LuChinina, V. A., Musatov, D. I. \& SIDORAS, S. D. 1976. Stratigrafiya pogranichnykh otlozhenij dokembriya i kembriya severa Anabarskogo podnyatiya. [Stratigraphy of transitional PrecambrianCambrian deposits of northern Anabar Uplift]. In Stratigrafiya $i$ paleontologiya nizhnego $i$ srednego kembriya SSSR. [Stratigraphy and palaeontology of the Lower and Middle Cambrian of the USSR.] (ed. I. T. Zhuravleva), pp. 3-22. Novosibirsk: Nauka.

MisSARZHEVSKY, V. V. 1974. Novye dannye o drevnejshikh okamenelostyakh rannego kembriya Sibirskoj platformy. [New data on the oldest fossils of the early Cambrian of the Siberian Platform.] In Biostratigrafiya $i$ paleontologiya nizhnego kembriya Evropy i severnoj Azii. [Biostratigraphy and palaeontology of the Lower Cambrian of Europe and northern Asia.] (eds I. T. Zhuravleva \& A. Yu. Rozanov), pp. 179-89. Moscow: Nauka (in Russian).

MisSARZHEVSKY, V. V. 1982. Raschlenenie i korrelyatsiya pogranichnykh tolsch dokembriya i kembriya po nekotorym drevnejshim gruppam skeletnykh organizmov. [Subdivision and correlation of the PrecambrianCambrian boundary beds using some groups of the oldest skeletal organisms.] Byulleten' Moskovskogo obschestva ispytatelej prirody, Otdelenie geologii 57(5), 52-67 (in Russian).

MisSARZHEVSKY, V. V. 1989. Drevnejshie skeletnye okamenelosti i stratigrafiya pogranichnykh tolshch dokembriya i kembriya. [The oldest skeletal fossils and stratigraphy of the Precambrian-Cambrian boundary beds.] Trudy Geologicheskogo Instituta AN SSSR 443, 237 pp. (in Russian)

MisSARZHEVSKY, V. V. \& MAMBETOV, A. M. 1981. Stratigrafiya i fauna pogranichnykh sloev kembriya $i$ dokembriya Malogo Karatau. [Stratigraphy and fauna of the Cambrian and Precambrian boundary beds of the Lesser Karatau Range.] Trudy Geologicheskogo Instituta AN SSSR 326, 92 pp. (in Russian)

MocZYDŁOWSKA, M. 2002. Early Cambrian phytoplankton diversification and appearance of trilobites in the
Swedish Caledonides with implications for coupled evolutionary events between primary producers and consumers. Lethaia 35, 191-214.

Moore, J. L., Porter, S. M., Steiner, M. \& Li, G. 2010. Cambrothyra ampulliformis, an unusual coelosceritophoran from the lower Cambrian of Shaanxi Province, China. Journal of Paleontology 84, 1040-60.

MülleR, K. J. 1959. Kambrische Conodonten. Zeitschrift der Deutschen Geologischen Gesellschaft 111, 43485.

MÜLlER, K. J. 1964. Ostracoda (Bradoriina) mit phosphatischen Gehäusen aus dem Oberkambrium von Schweden. Neues Jahrbuch für Geologie und Paläontologie, Abhandlungen 121, 1-46.

MÜLLER, K. J. 1971. Cambrian conodont faunas. Geological Society of America Memoir 127, 5-20.

Müller, W. E. G., LI, J., Schröder, H. C., QiaO, L. \& WANG, X. 2007. The unique skeleton of siliceous sponges (Porifera; Hexactinellida and Demospongiae) that evolved first from the Urmetazoa during the Proterozoic: a review. Biogeosciences 4, 219-32.

NARBONNE, G. M. 2005. The Ediacara biota: Neoproterozoic origin of animals and their ecosystems. Annual Review of Earth and Planetary Sciences 33, 421-42.

Narbonne, G. M., KaUfman, A. J. \& KnOll, A. H. 1994. Integrated chemostratigraphy and biostratigraphy of the Windermere Supergroup, northwestern Canada: implications for Neoproterozoic correlations and the early evolution of animals. Geological Society of America Bulletin 106, 1281-92.

NeAL, M. L. \& Hannibal, J. T. 2000. Paleoecologic and taxonomic implications of Sphenothallus and Sphenothallus-like specimens from Ohio and areas adjacent to Ohio. Journal of Paleontology 74, 369-80.

Neckaja, A. I. \& IVAnova, V. A. 1956. Pervaya nakhodka ostrakod v nizhnem kembrii Vostocjnoj Sibiri. [First find of ostracods in the Lower Cambrian of eastern Siberia.] Doklady AN SSSR 111(5), 1095-97.

OGG, J. G, OGG, G. \& Gradstein, F. M. 2008. The Concise Geologic Time Scale. Cambridge, New York, Melbourne: Cambridge University Press, 177 pp.

PARKhaEv, YU. P. 1998. Siphonoconcha - novyj klass rannekembriyskikh dvustvorchatykh organizmov. [Siphonoconcha - a new class of early Cambrian bivalved organisms.] Paleontologicheskiy zhurnal 1998(1), 3-16.

PeEL, J. S. 1991. The classes Tergomya and Helcionelloida, and early molluscan evolution. Bulletin Grønlands Geologiske Undersøgelse 161, 11-65.

PEL'MAN, YU. L. 1977. Ranne- i srednekembrijskie bezzamkovye brakhiopody Sibirskoj platformy. [Early and Middle Cambrian inarticulate brachiopods of the Siberian Platform.] Trudy Instituta Geologii i Geofiziki SO AN SSSR 316. Novosibirsk: Nauka, 168 pp.

PEL'MAN, YU. L. 1985. Novye stenotekoidy iz nizhnego kembriya Zapadnoj Mongolii [New stenothecoids from the Lower Cambrian of western Mongolia.] Trudy Instituta Geologii i Geofiziki SO AN SSSR 632, 10314. Novosibirsk: Nauka.

Pel'MAN, Yu. L., ERmak, V. V., Fedorov, A. B., Luchinina, V. A., Zhuravleva, I. T., RePINA, L. N., BondAREV, V. I. \& BorodaevsKaYA, Z. V. 1990. Novye dannye po stratigrafii i paleontologii verkhnego dokembriya i nizhnego kembriya r. Dzhandy (pravyj pritok $r$. Aldan). [New data on stratigraphy and palaeontology of the upper Precambrian and lower Cambrian of river Dzhandy (right tributary of river Aldan).] In Biostratigrafiya $i$ paleontologiya kembriya Severnoj 
Azii. [Biostratigraphy and palaeontology of the Cambrian of northern Asia.] (ed. L. N. Repina), pp. 3-32. Novosibirsk: Nauka (in Russian).

Pel'man, Yu. L., AKsarina, N. A., Koneva, S. P., Popov, L. Ye., Sobolev, L. P. \& Ushatinskaya, G. T. 1992. Drevneyshie brakhiopody territorii severnoy Evrazii. [The oldest brachiopods from the territory of northern Eurasia.] Novosibirsk: OIGGiM RAN, $145 \mathrm{pp}$.

PENG, J., ZHAO, Y.-L., WU, Y., YUAN, J.-L. \& TAI, T.-S. 2005. The Balang Fauna - a new early Cambrian Fauna from Kaili City, Guizhou Province. Chinese Science Bulletin 50, 1159-62.

PonOMARENKO, A. G. (ed.) 2005. Unikal'nye sinskiye mestonakhozhdeniya rannekembriyskikh organizmov (Sibirskaya platforma). [Unique Sinsk localities of Early Cambrian organisms (Siberian Platform).] Trudy Paleontologicheskogo Instituta 284, 143 pp.

Popov, L. E., BAssett, M. G., ZhevchuZhnikov, V. G., Holmer, L. E. \& KLISHEVICH, I. A. 2009. Gondwanan faunal signatures from Early Palaeozoic terranes of Kazakhstan and Central Asia: evidence and tectonic implications. In Early Palaeozoic Peri-Gondwana Terranes: New Insights from Tectonics and Biogeography (ed. M. G. Bassett), pp. 23-64. Geological Society of London, Special Publication no. 325.

PORTER, S. M. 2007. Seawater chemistry and early carbonate biomineralization. Science 316, 1302.

PORTER, S. M. 2008. Skeletal microstructure indicates chancelloriids and halkieriids are closely related. $\mathrm{Pa}$ laeontology 51, 865-79.

Pyle, L. J., NARbonNe, G. M., James, N. P., DalRyMPle, R. W. \& KAUFMAN, A. J. 2004. Integrated Ediacaran chronostratigraphy, Wernecke Mountains, northwestern Canada. Precambrian Research 132, 1-27

Pyle, L. J., Narbonne, G. M., Nowlan, G. S., Xiao, S. \& JAMES, N. P. 2006. Early Cambrian metazoan eggs, embryos, and phosphatic microfossils from northwestern Canada. Journal of Paleontology 80, 811-25.

QIAN, Y. 1978. The early Cambrian hyolithids in central and southwest China and their stratigraphical significance. Memoirs of Nanjing Institute of Geology and Palaeontology 11, 1-43 (in Chinese with English summary).

QIAN, Y. 1989. Early Cambrian small shelly fossils of China with special reference to the PrecambrianCambrian boundary. Stratigraphy and Palaeontology of Systemic Boundaries in China, Precambrian-Cambrian Boundary (2). Nanjing: Nanjing University Publishing House, $342 \mathrm{pp}$.

QIAN, Y. (ed.) 1999. Taxonomy and Biostratigraphy of Small Shelly Fossils in China. Beijing: Science Press, 247 pp. (in Chinese with English summary).

QIAN, Y. \& BENGTSON, S. 1989. Palaeontology and biostratigraphy of the Early Cambrian Meishucunian Stage in Yunnan Province, South China. Fossils and Strata 24, 1-156.

QIAN, Y., LI, G. \& ZHU, M. 2001 The Meishucunian Stage and its small shelly fossil sequence in China. Acta Palaeontological Sinica 40(Supplement), 54-62.

Qian, Y., Li, G.-X., ZhU, M.-Y., STEINER, M. \& ERDTMANN, B.-D. 2004. Early Cambrian protoconodonts and conodont-like fossils from China: taxonomic revisions and stratigraphic implications. Progress in Natural Science 14(2), 173-80.

QIAN, Y., VAN ITEN, H., CoX, R. S., ZHU, M.-Y. \& ZHUO, E.-J. 1997. A brief account of Emeiconularia trigemme, a new genus and species of protoconulariid. Acta Micropalaeontologica Sinica 14, 47588.
QIAN, Y. \& YIN, G. 1984. Zhijinitae and its stratigraphical significance. Acta Palaeontologica Sinica 23, 21623.

Qian, Y., ZhU, M., Li, G., JiAng, Z. \& VAn ITEN, H. 2002. A supplemental Precambrian-Cambrian boundary global stratotype section in SW China. Acta Palaeontologica Sinica 41, 19-26.

RAMSKÖLD, L. \& HOU, X. 1991. New early Cambrian animal and onychophoran affinities of enigmatic metazoans. Nature 351, 225-8.

Randell, R. D., Lieberman, B. S., Hasiotis, S. T. \& POPE, M. C. 2005. New chancelloriids from the Early Cambrian Sekwi Formation with a comment on chancelloriid affinities. Journal of Paleontology 79, 987-96.

RAYMOND, P. E. 1935. Leanchoilia and other mid-Cambrian Arthropoda. Bulletin of the Museum of Comparative Zoology, Harvard 46, 202-30.

REITNER, J. 1992. Coralline spongien der versuch einer phylogenetisch-taxonomischen Analyse. Berliner Geowissenshaftliche Abhandlungen E 1, 352 pp.

REITNER, J. \& WÖRHEIDE, G. 2002. Non-Lithistid fossil Demospongiae - origins of their palaeobiodiversity and highlights in history of preservation. In Systema Porifera: A guide to the classification of sponges (eds J. N. A. Hooper \& R. van Soest), pp. 52-68. New York: Kluwer.

Repina, L. N., Lazarenko, N. P., Meshova, N. P., KorshunOV, V. T., NiKIFOROV, N. T. \& AKSARINA, N. A. 1974. Biostratigraphy and fauna of the Lower Cambrian of the Kharulakh (Tuora-Sis Ridge). Moscow: Nauka, 299 pp.

Riding, R. \& ZhuraVleV, A. YU. 1995. Structure and diversity of oldest sponge-microbe reefs: Lower Cambrian, Aldan River, Siberia. Geology 23, 649-52.

RigBY, J. K. \& HoU, X.-G. 1995. Lower Cambrian demosponges and hexactinellid sponges from Yunnan, China. Journal of Paleontology 69, 1009-19.

Rowland, S. M., LUCHININA, V. A., KorovNiKOV, I. V., Sipin, D. P., TARletskov, A. \& FedoseeV, A. V. 1998. Biostratigraphy of the Vendian-Cambrian Sukharikha River section, northwestern Siberian Platform. Canadian Journal of Earth Sciences 35, 339-52.

Rozanov, A. Yu., Khomentovsky, V. V., SHabanov, Yu. Ya., Karlova, G. A., Varlamov, A. I., Luchinina, V. A., Pegel', T. V., Demidenko, Yu. E., ParkhaeV, P. YU., KorovniKoV, I. V. \& SKORLOTOVA, N. A. 2008. To the problem of stage subdivision of the Lower Cambrian. Stratigraphy and Geological Correlation 16(1), 1-19.

Rozanov, A. YU. \& MissarzheVsKy, V. V. 1966. Biostratigrafiya i fauna nizhnikh gorizontov kembriya. [Biostratigraphy and fauna of the lower horizons of the Cambrian.]. Trudy Geologicheskogo Instituta AN SSSR 148, $1-125$ (in Russian).

Rozanov, A. Y., Missarzhevsky, V. V., Volkova, N. A., Voronova, L. C., Krylov, I. N., Keller, B. M., Korolyuk, I. K., Lendzion, K., Michniak, R., PYKhOVA, N. G. \& Sidorov, A. D. 1969. Tommotskij jarus i problema nizhnej granizty kembrija. [The Tommotian Stage and the Cambrian lower boundary problem.] Trudy Geologicheskogo Instituta AN SSSR 206, 1-380. (In Russian; English edition: 1981, 359 pp. New Delhi: Amerind Publishing Co.).

Rozanov, A. Yu., Parkhaev, P. Yu., Demidenko, Yu. E., Karlova, G. A., Korovnikov, I. V., Shabanov, Yu. Ya., IVANTSOV, A. YU., LUCHININA, V. A., MALAKHOVSKAYA, YA. E., MEL'NIKOVA, L. M., NAIMARK, E. B., Ponomarenko, A. G., Skorlotova, N. A., 
SunduKOV, V. M., TOKAREV, D. A., UShatinsKaYA, G. T. \& KIPRIYANOVA, L. D. 2010. Iskopaemye stratotipov yarusov nizhnego kembriya. [Fossils from the Lower Cambrian Stage stratotypes.] Moscow: PIN RAN, $228 \mathrm{pp}$.

Rozanov, A. Yu., Repina, L. N., Apollonov, M. K., Shabanov, Yu. Ya., Zhuravlev, A. Yu., Pegel', T. V., Fedorov, A. B., Astashinin, V. A., Zhuravleva, I. T., Egorova, L. I., Chugaeva, M. N., Dubinina, S. V., ERMAK, V. V., ESAKOVA, N. V., SUNDUKOV, V. V., SuKHOV, S. S. \& ZHEMCHUZHNIKOV, V. G. 1992. Kembrij Sibiri. [The Cambrian of Siberia]. Novosibirsk: Nauka, $135 \mathrm{pp}$.

Rozanov, A. Yu. \& Sokolov, B. S. (eds.) 1984. Stage Subdivision of the Lower Cambrian. Stratigraphy. Moscow: Nauka (in Russian).

Rozanov, A. YU. \& ZhURAVleV, A. YU. 1992. The Lower Cambrian fossil record of the Soviet Union. In Origin and Early Evolution of the Metazoa (eds. J. H. Lipps \& P. W. Signor), pp. 205-82. New York: Plenum.

Rozov, S. N. 1984. Morfologiya, terminologiya, i sistematicheskoe polozhenie stenotekoid. [Morphology, terminology, and systematic affinity of stenothecoids.] Trudy Instituta Geologii i Geofiziki SO AN SSSR 597, 117-33.

RUNNEGAR, B. 1980. Hyolitha: status of the phylum. Lethaia 13, 21-5.

RunNeGAR, B. \& POJETA, J. 1974. Molluscan phylogeny: the paleontological viewpoint. Science 186, 311-17.

Runnegar, B., Pojeta, J., Morris, N. J., TAYlor, J. D., TAYLOR, M. E. \& MCClunG, G. 1975. Biology of the Hyolitha. Lethaia 8, 181-91.

RuzhentseV, S. V. \& Mossakovsky, A. A. 1995. Geodinamika i tektonikoe razvitie paleozoid tsentral'noy Azii kak rezul'tat vzaimodeystviya Tikhookeanskogo i IndoAtlanticheskogo segmentov Zemli. [Geodynamics and tectonic evolution of the Central Asian paleozoids as a result of interaction between the Pacific and IndoAtlantic segments of Earth]. Geotektonika 1995(4), 2947.

SALTER, J. W. 1864. On some new fossils from the Lingula flags of Wales. Quarterly Journal of the Geological Society of London 20, 233-41.

SAmuelson, J., VAN RoY, P. \& VeCOli, M. 2001. Micropalaeontology of a Moroccan Ordovician deposit yielding soft-bodied organisms showing Ediacara-like preservation. Geobios 34, 365-73.

SaWaKi, Y., NishizaWa, M., SUO, T., KOMIYA, T., HiRata, T., Takahata, N., Sano, Y., Han, J., Kon, Y. \& MARUYAMA, S. 2008. Internal structures and U-Pb ages of zircons from a tuff layer in the Meishucunian formation, Yunnan Province, South China. Gondwana Research 14(1-2), 148-58.

SAYUTINA, T. A. 1980. Rannekembrijskoe semejstvo Khasaktiidae fam. nov. - vozmozhnye stromatoporaty. [The Lower Cambrian family Khasaktiidae fam. nov. probable stromatoporates]. Paleontologicheskij Zhurnal 1980(4), 13-28. (English translation: Paleontological Journal 14(4), 13-30.)

Semikhatov, M. A. \& Serebryakov, S. N. 1983. The Siberian hypostratotype of the Riphean. Trudy Geologischeskogo Instituta AN SSSR 210, 1-207.

SEREZHNIKOVA, E. A. 2007 Palaeophragmodictya spinosa sp. nov., a bilateral benthic organism from the Vendian of the southeastern White Sea region. Paleontological Journal 41(4), 360-69.

Serezhnikova, E. A. \& Ivantsov, A. Yu. 2007. Fedomia mikhaili - a new spicule-bearing organism of sponge grade from the Vendian (Ediacaran) of the White Sea, Russia. Palaeoworld 16(4), 319-24.

Shabanov, Yu. Ya., Astashinin, V. A., Pegel, T. V., Egorova, L. I., ZhuraVleva, I. T., PEL'MAN, YU. L., SunduKov, V. M., Stepanova, M. V., SuKhov, S. S., Fedorov, A. B., Shishkin, B. B., Vaganova, N. V., ERMAK, V. I., RYABUKHA, K. V., YADRENKINA, A. G., Abaimova, G. P., LOPUSHINSKAYA, T. V., SYCHEV, O. V. \& Moskalenko, T. A. 1987. Nizhnij paleozoj yugozapadnogo sklona Anabarskoj anteklizy (po materialam bureniya). [Lower Palaeozoic of SW slope of the Anabar anticline (drill core material).] Novosibirsk: Nauka, $208 \mathrm{pp}$.

Shabanov, Yu. Ya., Korovnikov, I. V., Pereladov, V. S. \& FefElov, A. F. 2008. Excursion 1a. The traditional Lower-Middle Cambrian boundary in the Kuonamka Formation of the Molodo River section (the southeastern slope of the Olenek Uplift of the Siberian Platform) proposed as a candidate for GSSP of the lower boundary of the Middle Cambrian and its basal (Molodian) stage, define by the FAD of Ovatoryctocara granulata. In The Cambrian System of the Siberian Platform. Part 2: North-east of the Siberian Platform (eds A. Yu. Rozanov \& A. I. Varlamov). Moscow: PIN RAN and Novosibirsk, $140 \mathrm{pp}$.

Shergold, J. \& GeYer, G. 2003. The Subcommission on Cambrian stratigraphy: the status quo. Geologica Acta 1(1), 5-9.

Shu, D. G., LuO, H. L., Conway Morris, S., Zhang, X. L., Hu, S.-X., Chen, L., Han, J., ZHU, M., LI, Y. \& CHEN, L.-Z. 1999. Lower Cambrian vertebrates from south China. Nature 402, 42-6.

Shu, D., VANNIER, J., LUO, H.-L., ChEN, L.-Z., ZhANG, X.-L. \& HU, S.-X. 1999 Anatomy and lifestyle of Kunmingella (Arthropoda, Bradoriida) from the Chengjiang fossil Lagerstätte (Lower Cambrian, southwest China). Lethaia 32, 279-98.

SIGNOR, P. W. 1992. Evolutionary and tectonic implications of Early Cambrian faunal endemism. In The History of Water: Eastern Sierra Nevada, Owens Valley, WhiteInyo Mountains (eds C. A. Hall, Jr., V. Doyle-Jones \& B. Widawski), pp. 1-13. White Mountain Research Station Symposium, vol. 4. Los Angeles: Regents of the University of California.

Skovsted, C. B. 2003. Mobergellans (Problematica) from the Cambrian of Greenland, Siberia and Kazakhstan. Paläontologische Zeitschrift 77, 429-43.

Skovsted, C. B. 2004. The mollusc fauna of the Early Cambrian Bastion Formation of North-East Greenland. Bulletin of the Geological Society of Denmark 51, 1137.

Skovsted, C. B. 2006. Small Shelly fauna from the upper Lower Cambrian Bastion and Ella Island formations, north-east Greenland. Journal of Paleontology 80, 1087-112.

Skovsted, C. B., Balthasar, U., Brock, G. A. \& PAterson, J. R. 2009a. The tommotiid Camenella reticulosa from the lower Cambrian of South Australia, scleritome reconstructions and tommotiid phylogeny. Acta Palaeontologica Polonica 54, 525-40.

Skovsted, C. B., Brock, G. A. \& PAterson, J. R. 2006. Bivalved arthropods from the Lower Cambrian Mernmerna Formation of South Australia and their implications for the identification of Cambrian "small shelly fossils". Memoirs of the Association of Australasian Palaeontologists 32, 7-41.

Skovsted, C. B., Brock, G. A., Paterson, J. R., Holmer, L. E. \& BUDD, G. E. 2008. The scleritome of 
Eccentrotheca from the Lower Cambrian of South Australia: lophophorate affinities and implications for tommotiid phylogeny. Geology 36, 171-4.

Skovsted, C. B., Holmer, L. E., Larsson, C. M., Högström, A. E. S., Brock, G. A., Topper, T. P., Balthasar, U., Petterson Stolk, S. \& Paterson, J. P. 2009b. The scleritome of Paterimitra: an Early Cambrian stem group brachiopod from South Australia. Proceedings of the Royal Society of London B 276, 1651-6.

Skovsted, C. B., Holmer, L. E., Topper, T. P. \& Brock, G. A. 2010. Brachiopod affinity of the Lower Cambrian problematic bivalve Apistoconcha. International Palaeontological Congress, London, June, 28-July, 3, Abstracts with programme, p. 356.

Skovsted, C. B. \& PeEL, J. S. 2011. Hyolithellus in life position from the lower Cambrian of North Greenland. Journal of Paleontology 85, 37-47.

SMITH, M. P. \& SANSOM, I. J. 1995. The affinity of Anatolepis. Geobios 28(Supplement 2), 61-3.

Smith, M. P., SAnsom, I. J. \& Cochrane, K. D. 2001. The Cambrian origin of vertebrates. In Major Events in Early vertebrate Evolution - Palaeontology, phylogeny, genetics, and development (ed. P. E. Ahlberg), pp. 67-84. The Systematics Association Special Volume 61.

SMITH, M. P., SANSOM, I. J. \& REPETSKI, J. E. 1996. Histology of the first fish. Nature 380, 702-4.

SNODGRASS, R. E. 1938. Evolution of the Annelida, Onychophora, and Arthropoda. Smithsonian Miscellaneous Collections 97(6), 1-159.

SoKolov, B. S. \& ZHuRAVleva, I. T. (eds) 1983. Yarusnoe raschlenenie nizhnego kembriya Sibiri. Atlas okamenelostej. [Stage subdivision of the Lower Cambrian of Siberia. Atlas of fossils.] Trudy Instituta Geologii i Geofiziki SO AN SSSR 558, 1-216.

Sperling, E. A., Pisani, D. \& Peterson, K. J. 2007. Poriferan paraphyly and its implications for Precambrian palaeobiology. In The Rise and Fall of the Ediacaran Biota (eds P. Vickers-Rich \& P. Komarower), pp. 35568. Geological Society of London, Special Publication no. 286 .

SPRINKLE, J. 1973. Morphology and Evolution of Blastozoan Echinoderms. Harvard University Museum of Comparative Zoology, Special Publication, 283 pp.

STANLEY, S. M. \& HARDIE, L. A. 1998. Secular oscillations in the carbonate mineralogy of reefbuilding and sedimentproducing organisms driven by tectonically forced shifts in seawater chemistry. Palaeogeography, Palaeoclimatology, Palaeoecology 144, 3-19.

SteINER, M. \& LI, G. 2010. Cambrian Small Shelly Fossils and the taphonomic phosphatization window. International Palaeontological Congress, London, June, 28-July, 3, Abstracts with programme, p. 363.

SteIner, M., LI, G., QIAN, Y. \& ZHU, M. 2004a. Lower Cambrian Small Shelly Fossils of northern Sichuan and southern Shaanxi (China), and their biostratigraphic importance. Geobios 37, 259-75.

SteInER, M., LI, G.-X., QIAN, Y., ZHU, M.-Y. \& ERDTMANN, B.-D. 2007. Neoproterozoic to Early Cambrian Small Shelly assemblages of the Yangtze Platform (China) and their potential for regional and international correlation. Palaeogeography, Palaeoclimatology, Palaeoecology 254, 67-99.

Steiner, M., Mehl, D., Reitner, J. \& ERDTMAnN, B.-D. 1993. Oldest entirely preserved sponges and other fossils from the lowermost Cambrian and a new facies reconstruction of the Yangtze platform (China).
Berliner Geowissenschaftlich Abhandlungern E 9, 293 329.

Steiner, M., ZhU, M., Li, G., Qian, Y. \& ERdTMAnN, B.-D. 2004b. New Early Cambrian bilaterian embryos and larvae from China.Geology 32, 833-36.

Steiner, M., Zhu, M., Weber, B. \& Geyer, G. 2001. The Lower Cambrian of Eastern Yunnan: trilobite-based biostratigraphy and related faunas. Acta Palaeontologica Sinica 40(Supplement), 63-79.

Streng, M., EBbestad, J. O. R. \& MoczydŁowsKA, M. 2008. A Walcottella-like bradoriid (Arthropoda) from the lower Cambrian of Sweden. GFF 130, 11-9.

StrenG, M. \& Skovsted, C. B. 2006. A new mobergellan (small shelly fossils) from the early Middle Cambrian of Morocco and its significance. Paläontologische Zeitschrift 80/3, 209-20.

Sysoev, V. A. 1962. Khiolity kembriya severnogo sklona Aldanskogo shchita. [Cambrian hyolithids from the northern slope of the Aldan shield.] Yakutian Filial of SO AN SSSR, $66 \mathrm{pp}$.

SZANIAWSKI, H. 1982. Chaetognath grasping spines recognized among Cambrian protoconodonts. Journal of Paleontology 56, 806-10.

SZANIAWSKI, H. 2002. New evidence for the protoconodont origin of chaetognaths. Acta Palaeontologica Polonica 47, 405-19.

SZANIAWSKI, H. \& BENGTSON, S. 1993. Origin of euconodont elements. Journal of Paleontology 67, 640-54.

SzANIAWSKI, H. \& BENGTSON, S. 1998. Late Cambrian euconodonts from Sweden. In Proceedings of the Sixth European Conodont Symposium (ECOS VI) (ed. H. Szaniawski). Palaeontologia Polonica 58, 7-29.

TANG, T., Zhang, J. \& JiAnG, X. 1978. Discovery and significance of the Late Sinian fauna from western Hunan and Hubei. Acta Stratigraphica Sinica 2, 32-45.

ThOMAS, R. D. K., SHERMAN, R. M. \& STEWART, C. W. 2000. Evolutionary exploitation of design options by the first animals with hard skeletons. Science 288, 1239-42.

TIWARI, M. 1999. Organic-walled microfossils from the Chert-Phosphate Member, Tal Formation, PrecambrianCambrian boundary, India. Precambrian Research 97, 99-113.

TiWari, M., PANT, C. C. \& TeWARI, V. C. 2000. Neoproterozoic sponge spicules and organic-walled microfossils from the Gangolihat Dolomite, Lesser Himalaya, India. Current Science 79(5), 651-4.

Topper, T. P., Brock, G. A., Skovsted, C. B. \& PATERson, J. R. 2010. Palaeoscolecid scleritome fragments with Hadimopanella plates from the early Cambrian of South Australia. Geological Magazine 147, 86-97.

TOPPER, T. P., SKovsted, C. B., BROCK, G. A. \& PATERSON, J. R. 2011. The oldest bivalved arthropods from the early Cambrian of East Gondwana: systematics, biostratigraphy and biogeography. Gondwana Research 19, 310-26.

USHATINSKAYA, G. T. 1987. Neobychnye bezzamkovye brakhiopody iz nizhnego kembriya Mongolii. [Unusual inarticulate brachiopods from the Lower Cambrian of Mongolia.] Paleontologicheskij Zhurnal 1987(2), 628. (English translation: Paleontological Journal 21(2), 59-66.)

USHATINSKAYA, G. T. \& MALAKHOVSKAYA, YA. E. 2001. Origin and development of the Cambrian brachiopod biochores. Stratigraphy and Geological Correlation 9(6), 540-56.

UshatinskaYA, G. T. \& ZhURAVLEV, A. YU. 1994. K probleme mineralizatsii skeleta (na primere brakhiopod). [To the problem on skeletal biomineralization (exemplified 
by brachiopods).] Doklady Akademii Nauk 337(2), 2314 (in Russian).

VAL'KOV, A. K. 1982. Biostratigrafiya nizhnego kembriya vostoka Sibirskoj platformy (Uchuro-Majskij rajon). [Biostratigraphy of the Lower Cambrian of eastern Siberian platform (Utchur-Maya region)]. Moscow: Nauka, 91 pp. (in Russian)

VAL'KOV, A. K. 1987. Biostratigrafija nizhnego kembrija vostoka Sibirskoj platformy (Yudoma-Oleniokskij region). [Biostratigraphy of the Lower Cambrian of eastern Siberian Platform (Yudoma-Oleniok region)]. Moscow: Nauka, 136 pp. (in Russian)

VAn ITEN, H., Vyhlasova, Z., ZhU, M.-Y. \& QIan, Y. 2005. Widespread occurrence of microscopic pores in conulariids. Journal of Paleontology 79, 400-7.

VAN ITEN, H., ZHU, M.-Y. \& COLLINS, D. 2002. First report of Sphenothallus Hall, 1847 in the Middle Cambrian. Journal of Paleontology 76, 902-5.

VAN ITEN, H., ZHU, M.-Y. \& LI, G. 2010. Redescription of Hexaconularia He and Yang, 1986 (Lower Cambrian, South China): implications for the affinities of conulariid-like small shelly fossils. Palaeontology 53, 191-9.

VAnnier, J., Steiner, M., Renvoise, E., Hu, S.-X. \& CASANOVA, J.-P. 2007. Early Cambrian origin of modern food webs: evidence from predator arrow worms. Proceedings of the Royal Society B 274, 627-33.

Varlamov, A. I., Rozanov, A. YU., Khomentovsky, V. V., Shabanov, Yu. Ya., Abaimova, G. P., DemidenKo, YU. E., KARlova, G. A., KorovNIKOV, I. V., LUCHININA, V. A., Malakhovskaya, Ya. E., Parkhaev, P. Yu., Pegel, T. V., Skorlotova, N. A., Sundukov, V. M., Sukhov, S. S., Fedorov, A. B. \& Kipriyanova, L. D. 2008. The Cambrian System of the Siberian Platform. Part 1: The Aldan-Lena region. Moscow-Novosibirsk: PIN RAN, 300 pp.

Vendrasco, M. J., Li, G., Porter, S. M. \& Fernandez, C. Z. 2009. New data on the enigmatic OcruranusEohalobia group of early Cambrian small skeletal fossils. Palaeontology 52, 1373-96.

Voronin, Y. I., Voronova, L. G., Grigor'eVA, N. V., Drozdova, N. A., Zhegallo, E. A., ZhuraVlev, A. Yu., Ragozina, A. L., Rozanov, A. Yu., SaYUTINA, T. A., SysoevA, V. A. \& Fonin, V. D. 1982. Granitsa dokembriya i kembriya $v$ geosinklinal'nykh oblastyakh (opornyj razrez Salany-Gol, MNR). [The Precambrian-Cambrian boundary in the geosynclinal regions (reference section Salany-Gol, MNR).] Trudy Sovmestnoj sovetsko-mongol'skoj paleontologicheskoj ehkspeditsii.Volume 18. Moscow: Nauka, 150 pp. (in Russian)

Voronova, L. G., Drosdova, N. A., Esakova, N. V., Zhegallo, E. A., Zhuravlev, A. Yu., Rozanov, A. Yu., Sayutina, T. A. \& Ushatinskaya, G. T. 1987. Iskopaemye nizhnego kembriya gor Makkenzi (Kanada). [Lower Cambrian fossils from the Mackenzie Mountains (Canada).] Trudy Paleontologicheskogo Instituta AN SSSR 224, 88 pp. (in Russian)

VostokovA, V. A. 1962. Kembrijskie gastropody Sibrskoj platformy i Tajmyra. [The Cambrian gastropods from Siberia and Tajmyr.] Trudy Nauchno-Issledovatel'skogo Instituta Geologii Arktiki 28, 51-74 (in Russian).

WALCOTT, C. D. 1889. Stratigraphic position of the Olenellus fauna in North America and Europe. American Journal of Science 38, 374-92.

WalcotT, C. D. 1920. Middle Cambrian Spongiae. Smithsonian Miscellaneous Collections 67, 261-364.

Weber, B., Steiner, M. \& ZHU, M. 2007. PrecambrianCambrian trace fossils from the Yangtze Platform (South
China) and the early evolution of bilaterian lifestyles. Palaeogeography, Palaeoclimatology, Palaeoecology 254, 328-49.

WeBER, B. \& ZHU, M. 2003. Arthropod trace fossils from the Zhujiaqing Formation (Meishucunian, Yunnan) and their palaeobiological implications. Progress in Natural Science 13(10), 795-800.

Wilmot, N. V. \& FAllick, A. E. 1989. Original mineralogy of trilobite exoskeletons. Palaeontology 32, 297-304.

Williams, A. \& Holmer, L. E. 2002. Shell structure and inferred growth, functions and affinities of the sclerites of the problematic Micrina. Palaeontology 45, 845-73.

Williams, M., Siveter, D. J., Popov, L. E. \& VANNIER, J. M. C. 2007 Biogeography and affinities of the bradoriid arthropods: cosmopolitan microbenthos of the Cambrian seas. Palaeogeography, Palaeoclimatology, Palaeoecology 248, 202-32.

Wood, R. A., Grotzinger, J. P. \& Dickson, J. A. D. 2002. Proterozoic modular biomineralized metazoan from the Nama Group, Namibia. Science 296, 2383-6.

WronA, R. 1982. Early Cambrian phosphatic microfossils from southern Spitsbergen (Horsund region). Palaeontologia Polonica 43, 9-16.

Xing, Y., Ding, Q., LuO, H., He, T. \& Wang, Y. 1984 (but data on cover is 1983). The Sinian-Cambrian boundary of China. Bulletin of the Institute of Geology, Chinese Academy of Geological Sciences 10, 262 pp. (in Chinese)

YOCHELSON, E. L. 1969. Stenothecoida, a proposed new class of Cambrian Mollusca. Lethaia 2, 49-62.

YounG, G. C. 2009. An Ordovician vertebrate from western New South Wales, with comments on CambroOrdovician vertebrate distribution patterns. Alcheringa 33, 79-89.

YU, W. 1996. Early Cambrian stenothecoid molluscs from China. Records of the Western Australian Museum 18, 209-17.

Yuan, X., Xiao, S., Parsley, R. L., Zhou, C., Chen, Z. \& HU, J. 2002. Towering sponges in an Early Cambrian Lagerstätte: disparity between nonbilaterian and bilaterian epifaunal tiers at the NeoproterozoicCambrian transition. Geology 30, 363-6.

Zamora, S., Lefebvre, B., Álvaro, J. J., Clausen, S., Elicki, O., FATKA, O., Jell, P., KoUChInSKY, A., Lin, J.-P., Nardin, E., Parsley, R., Rozhnov, S., Sprinkle, J., Sumrall, C. D., Vizcaïno, D. \& SMith, A. B. In press. Cambrian echinoderm diversity and palaeobiogeography. In Early Palaeozoic Palaeography and Biogeography (eds. D. Harper \& T. Servais). Geological Society of London, Special Publication.

ZHANG, X.-G. 2007. Phosphatized bradoriids (Arthropoda) from the Cambrian of China. Palaeontographica, $A b$ teilung $A$ 281, 93-173.

ZHANG, W. \& BABCOCK, L. E. 2001. New extraordinarily preserved enigmatic fossils, possibly with Ediacaran affinities, from the Lower Cambrian of Yunnan, China. Acta Palaeontologica Sinica 40(Supplement), 201-13.

ZhANG, H., DONG, X.-P. \& MAAS, A. 2011. Hesslandona angustata (Phosphatocopida, Crustacea) from the Upper Cambrian of western Hunan, South China, with comments on phosphatocopid phylogeny. Neues Jahrbuch für Geologie und Paläontologie 259, 157-75.

ZHANG, Y., YUAN, X. \& YIN, L. 1998. Interpreting Late Precambrian microfossils. Science 282, 1783.

ZHAO, Z., XING, Y., DING, Q., LIU, G., ZHAO, Y., ZHANG, S., Meng, X., Yin, C., Ning, B. \& Han, P. 1988. The Sinian System of Hubei. Wuhan: China University of Geosciences Press, 205 pp. 
Zhou, C., Yuan, X. \& Xue, Y. 1998. Sponge spiculelike pseudofossils from the Neoproterozoic Toushantou Formation in Weng'an, Guizhou, China. Acta Micropalaeontologica Sinica 15, 380-4.

Zhu, R.-X., LI, X.-H., Hou, X., PAN, Y.-X., WANG, F., DenG, C.-L. \& HE, H.-Y. 2009. SIMS U-Pb zircon age of a tuff layer in the Meishucun section, Yunnan, southwest China: constraint on the age of the PrecambrianCambrian boundary. Science in China, Series D-Earth Sciences 52(9), 1385-92.

Zhu, M., Li, G., Zhang, J., Steiner, M., Qian, Y. \& JiAnG, Z. 2001 Early Cambrian stratigraphy of east Yunnan, southwest China: a synthesis. Acta Palaeontologica Sinica 40(Supplement), 4-39.

ZhuraVleV, A. YU. 1993. Early Cambrian steps of biomineralization: mineralogy. 7th International Symposium on Biomineralization, Monaco. Biomineralization 93, p. 103.

ZhuRAVLEV, A. YU. 1995. Preliminary suggestions of the global Early Cambrian Zonation. Beringeria Special Issue 2, 147-60.

ZhURAVLEV, A. YU. 2001. Biotic diversity and structure during the Neoproterozoic-Ordovician transition. In The Ecology of the Cambrian Radiation (eds A. Yu. Zhuravlev \& R. Riding), pp. 173-99. New York: Columbia University Press.

Zhuravlev, A. Yu., LiÑán, E., GÁMEZ Vintaned, J. A., Debrenne, F. \& Fedorov, A. B. 2011. New finds of skeletal fossils in the terminal Neoproterozoic of the Siberian Platform and Spain. Acta Palaeontologica Polonica, doi: 10.4202/app.2010.0074.

Zhuravlev, A. Yu. \& Wood, R. A. 1996. Anoxia as the cause of the mid-Early Cambrian (Botomian) extinction event. Geology 24, 311-4.

ZHURAVLEV, A. YU. \& WoOD, R. A. 2008. Eve of biomineralization: controls on skeletal mineralogy. Geology 36, 923-6.

ZHURAVLEVA, I. T. 1955. K poznaniyu archeotsiat Sibiri. [To the understanding of archaeocyaths from Siberia.] Doklady AN SSSR 104(4), 626-9.

\section{Appendix 1}

Siberian first appearances in the Nemakit-Daldynian Stage (see Fig. 4)

S1. Sclerites of protoconodonts Protohertzina anabarica and $P$. unguliformis (Nemnekey; Khomentovsky \& Karlova, 1991, 1993; projected onto the Siberian $\delta^{13} \mathrm{C}$ reference scale by Brasier, Khomentovsky \& Corfield, 1993).

Remarks. Anabaritids are also reported from this level and below the Precambrian-Cambrian boundary negative excursion (see data in online Appendix 1 at http:// journals.cambridge.org/geo, not shown in Fig. 4).

S2. Shelly molluscs Oelandiella sp. and Barskovia sp., halwaxiids Purella cristata, Siphogonuchites aff. triangularis, and orthothecid hyoliths Lophotheca socialis (Mt Konus; Khomentovsky, Val'kov \& Karlova, 1990; projected onto the Siberian $\delta^{13} \mathrm{C}$ reference scale by Brasier, Khomentovsky \& Corfield, 1993).

Remarks. Spicules of hexactinellids Protospongia sp. and ?sclerites of chancelloriids Chancelloria sp. are also reported from that level (Gonam; Khomentovsky \& Karlova, 1993; projected herein onto the Siberian $\delta^{13} \mathrm{C}$ reference scale in accordance with Brasier, Khomentovsky \& Corfield, 1993).

S3. Tubes of hyolithelminths Hyolithellus sp., sclerites of chancelloriids Chancelloria sp., problematic sclerites of Fomitchella cf. infundibuliformis (Gonam;
Semikhatov \& Serebryakov, 1983; Khomentovsky et al. 1983; Khomentovsky \& Karlova, 1993; projected herein onto the Siberian $\delta^{13} \mathrm{C}$ reference scale in accordance with Brasier, Khomentovsky \& Corfield, 1993).

\section{Siberian first appearances in the Tommotian Stage (see Fig. 4)}

S4. Tommotiid Sunnaginia imbricata, archaeocyaths, siliceous stauracts and pentacts of the hexactinellid sponges (Aldan; Sokolov \& Zhuravleva, 1983; Rozanov \& Sokolov, 1984; Shabanov et al. 2008); problematic tubes Tommototubulus savitzkyi Fedorov, 1986 (Aldan; Khomentovsky, Val'kov \& Karlova, 1990).

S5. Calcium-phosphate brachiopods Aldanotreta sunnaginensis (Aldan; Sokolov \& Zhuravleva, 1983; Rozanov \& Sokolov, 1984; Bengtson et al. 1987; Ushatinskaya \& Malakhovskaya, 2001); problematic sclerites Tumulduria incomperta (Aldan; Sokolov \& Zhuravleva, 1983; Rozanov \& Sokolov, 1984; Bengtson et al. 1987; Rozanov et al. 1992) and Archaeopetasus sp. (as opercula of Coleolella billingsi in Rozanov et al. 1969, pl. 7) (Aldan; Rozanov et al. 1969; Bengtson et al. 1990; Dzik, 1994); problematic tubes Coleolella billingsi (Sysoev, 1962) (Aldan; Rozanov et al. 1969; Sokolov \& Zhuravleva, 1983), 'Coleolus' trigonus Sysoev, 1962 (Aldan; Sysoev, 1962; Rozanov et al. 1969), and Coleoloides trigeminatus Missarzhevsky in Rozanov et al. 1969 (Aldan; Sokolov \& Zhuravleva, 1983).

S6. Spicules of the calcarean sponge Dodecaactinella sp. and thecae of corallomorph Cysticyathus tunicatus (Middle Lena; Kruse, Zhuravlev \& James, 1995).

S7. Mobergella sibirica Skovsted, 2003 (formerly Mobergella radiolata Bengtson, 1968) (Aldan; Rozanov et al. 1969; Sokolov \& Zhuravleva, 1983; Rozanov \& Sokolov, 1984; Missarzhevsky, 1989; Rozanov \& Zhuravlev, 1992).

S8. Calcium-carbonate brachiopods Nochoroiella isitica and Obolella sp. (Middle Lena; Grigor'eva, Melnikova \& Pel'man, 1983; Sokolov \& Zhuravleva, 1983; Rozanov \& Sokolov 1984; Pel'man et al. 1992;

S9. Problematic sclerites Rhombocorniculum insolutum (Middle Lena; Sokolov \& Zhuravleva, 1983; Rozanov \& Sokolov, 1984; Brasier, 1989b; Rozanov \& Zhuravlev, 1992. Bol'shaya Kuonamka; Kouchinsky et al., unpub. data and herein).

\section{Siberian first appearances in the Atdabanian Stage (see Fig. 4)}

S10. Trilobites Profallotaspis sp. (Middle Lena; Rozanov \& Sokolov, 1984).

S11. Microdictyon sp. (Bol'shaya Kuonamka; Kouchinsky et al., unpub. data and herein).

S12. Eocrinoidea indet. (Bol'shaya Kuonamka; Kouchinsky et al., unpub. data and herein).

S13. Hadimopanella apicata (Bol'shaya Kuonamka; Kouchinsky et al., unpub. data and herein).

\section{Appendix 2}

\section{Mongolian first appearances (see Fig. 5)}

M1. Hexactinellid spicules (Brasier et al. 1996, fig. 5; Braiser, Green \& Shields, 1997); anabaritids A. trisulcatus and C. decurvatus (Brasier et al. 1996; Esakova \& Zhegallo, 
1996; Khomentovsky \& Gibsher, 1996) or Anabarites sp. (Esakova \& Zhegallo, 1996).

M2. Protoconodonts Protohertzina unguliformis; scaly shells of halwaxiids Purella sp.; orthothecid? hyoliths Pseudorthotheca bicostata Qian (indicated as P. bistriata in Khomentovsky \& Gibsher, 1996, fig. 13, p. 386) (Brasier et al. 1996, fig. 9; Khomentovsky \& Gibsher, 1996, fig. 13).

M3. Tommotiids Camenella applanata and Camenella sp. (Khomentovsky \& Gibsher, 1996, fig. 3 on p. 386; Brasier et al. 1996), Camenella cf. baltica (Voronin et al. 1982); problematic tubes Hyolithellus cf. vladimirovae (Brasier et al. 1996) or Hyolithellus sp. (Voronin et al. 1982) and Coleolella billingsi (Brasier et al. 1996, figs 6, 7).

M4. Shelled molluses Obtusoconus honorabilis and Granoconus trematus (Khomentovsky \& Gibsher, 1996).

M5. Sclerites of chancelloriids Chancelloria sp. (Voronin et al. 1982).

M6. Calcium carbonate-shelled brachiopod? Khasagtina primaria Ushatinskaya, 1987 (described as Kundatella sp. by Voronin et al. 1982).

M7. Stenothecoides sp. (Voronin et al. 1982; Khomentovsky \& Gibsher, 1996, fig. 13). 